\title{
Pre-Clinical Models in Implant Dentistry: Past, Present, Future
}

\author{
Nicolas Blanc-Sylvestre ${ }^{1,2} \mathbb{1}$, Philippe Bouchard ${ }^{1,2}$, Catherine Chaussain ${ }^{1,3}$ and Claire Bardet ${ }^{1, *}$ \\ 1 Université de Paris, Institut des Maladies Musculo-Squelettiques, Orofacial Pathologies, Imaging \\ and Biotherapies Laboratory URP2496 and FHU-DDS-Net, Dental School, and Plateforme d'Imagerie du \\ Vivant (PIV), 92120 Montrouge, France; nicolasbs.efp@gmail.com (N.B.-S.); \\ philippe.bouchard.perio@gmail.com (P.B.); catherine.chaussain@u-paris.fr (C.C.) \\ 2 AP-HP, Department of Periodontology, Rothschild Hospital, European Postgraduate in Periodontology \\ and Implantology, Université de Paris, 75012 Paris, France \\ 3 AP-HP, Reference Center for Rare Disorders of the Calcium and Phosphate Metabolism, Dental Medicine \\ Department, Bretonneau Hospital, GHN-Université de Paris, 75018 Paris, France \\ * Correspondence: claire.bardet@u-paris.fr; Tel.: +33-1-5807-6724
}

Citation: Blanc-Sylvestre, N.; Bouchard, P.; Chaussain, C.; Bardet, C. Pre-Clinical Models in Implant Dentistry: Past, Present, Future Biomedicines 2021, 9, 1538. https:// doi.org/10.3390/biomedicines 9111538

Academic Editors: Federico Mussano, Giulio Preti, Davide Cavagnetto and Gianluca Gambarini

Received: 9 September 2021

Accepted: 15 October 2021

Published: 26 October 2021

Publisher's Note: MDPI stays neutral with regard to jurisdictional claims in published maps and institutional affiliations.

Copyright: (c) 2021 by the authors. Licensee MDPI, Basel, Switzerland. This article is an open access article distributed under the terms and conditions of the Creative Commons Attribution (CC BY) license (https:// creativecommons.org/licenses/by/ $4.0 /)$.
Abstract: Biomedical research seeks to generate experimental results for translation to clinical settings. In order to improve the transition from bench to bedside, researchers must draw justifiable conclusions based on data from an appropriate model. Animal testing, as a prerequisite to human clinical exposure, is performed in a range of species, from laboratory mice to larger animals (such as dogs or non-human primates). Minipigs appear to be the animal of choice for studying bone surgery around intraoral dental implants. Dog models, well-known in the field of dental implant research, tend now to be used for studies conducted under compromised oral conditions (biofilm). Regarding small animal models, research studies mostly use rodents, with interest in rabbit models declining. Mouse models remain a reference for genetic studies. On the other hand, over the last decade, scientific advances and government guidelines have led to the replacement, reduction, and refinement of the use of all animal models in dental implant research. In new development strategies, some in vivo experiments are being progressively replaced by in vitro or biomaterial approaches. In this review, we summarize the key information on the animal models currently available for dental implant research and highlight (i) the pros and cons of each type, (ii) new levels of decisional procedures regarding study objectives, and (iii) the outlook for animal research, discussing possible non-animal options.

Keywords: pre-clinical research; murine dental implant; human-sized dental implant; osseointegration; biocompatibility; implant models

\section{Introduction}

In the field of dental implant research, experiments have been mainly limited to in vivo studies in so far as translational studies are a prerequisite for any clinical research. Identification of the reasons for the failure and success of dental implant treatments remains the most frequent question in clinical practice. By mimicking the biological condition of an implant, pre-clinical research makes it possible to investigate aspects of peri-implant tissue healing and peri-implant disease development [1].

Traditionally, two types of in vivo implant studies have been conducted depending on the implant size used: (1) experiments in large animal models (dogs, pigs, and non-human primates [NHPs]) for studying human-sized implants and (2) experiments in small animal models (rabbits, mice, and rats) for studying adapted "implants" (Figure 1). Nonetheless, taken separately, no animal model is able to shed light on all three levels of implant osseointegration (macro/micro/nano). For example, assessment of implant occlusion (macro level) is limited to large animal models, but these models do not allow the analysis of molecular interaction at the bone/implant interface (micro level). Moreover, limiting the selection criteria to animal size amounts to ignoring other species-specific characteristics 
(anatomy, physiology, etc.) of each model. Overall, animal model justification in implant studies is complex and requires decision support tools.

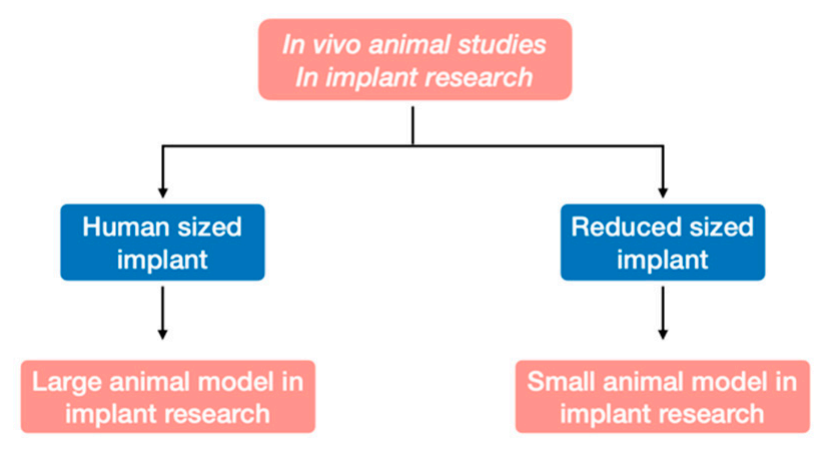

Figure 1. Conventional decision tree for animal model selection in dental implant research: large vs. small animal models.

Since the 1950s, researchers have been widely encouraged to find alternatives to animal testing and improve animal welfare and research quality. In many countries, the principles of Replacement, Reduction, and Refinement (the "3Rs") are now embedded in national and international legislation, redefining the use of animals in scientific procedures with the establishment of the ARRIVE (Animal Research: Reporting of In Vivo Experiments) guidelines [1-3]. Nowadays, in vitro studies play a leading role in the development of tissue bioprinting, organoids, or organ-on-a-chip, which have emerged as promising approaches for replacing animal experiments in basic research. Guided by the principles of the 3Rs, trends in use as a function of this size-based classification have changed, with large animal models mainly being used for clinical studies, small animal models employed preferentially for pathophysiological pathway analysis [4], and the substantial development of in vitro methods.

The present review aims to clarify these trends in the use of animal models in dental implant research and highlights the pros and cons of each of these models. It also discusses the outlook for animal research and emerging decisional procedures regarding study objectives, as well as currently available and promising non-animal options.

\section{Large Animal Models in Implantology}

\subsection{Non-Human Primate Models}

Many species of NHPs have been used as bone disease models due to similarities of their physiology to that of humans. NHPs have considerable genetic homology with humans, which allows the use of numerous human probes for genetic studies [5]. Further, they develop similar bone diseases to humans, such as osteoporosis and age-related bone loss [6,7].

\section{Pros and Cons of the Models}

NHPs were naturally chosen for dental procedures for their dental similarities with two dentitions (deciduous and permanent teeth). Even if periodontitis does not often occur naturally, plaque accumulation may occur, potentially progressing to gingival inflammation [8]. They are therefore one of the best models for oral procedures, including dental implant surgery. On the other hand, these similarities are also considered a disadvantage in fundamental research where procedures tend to be as short as possible, protocol duration in NHPs being the longest compared to all other models (Figure 2, Appendix A.1). 


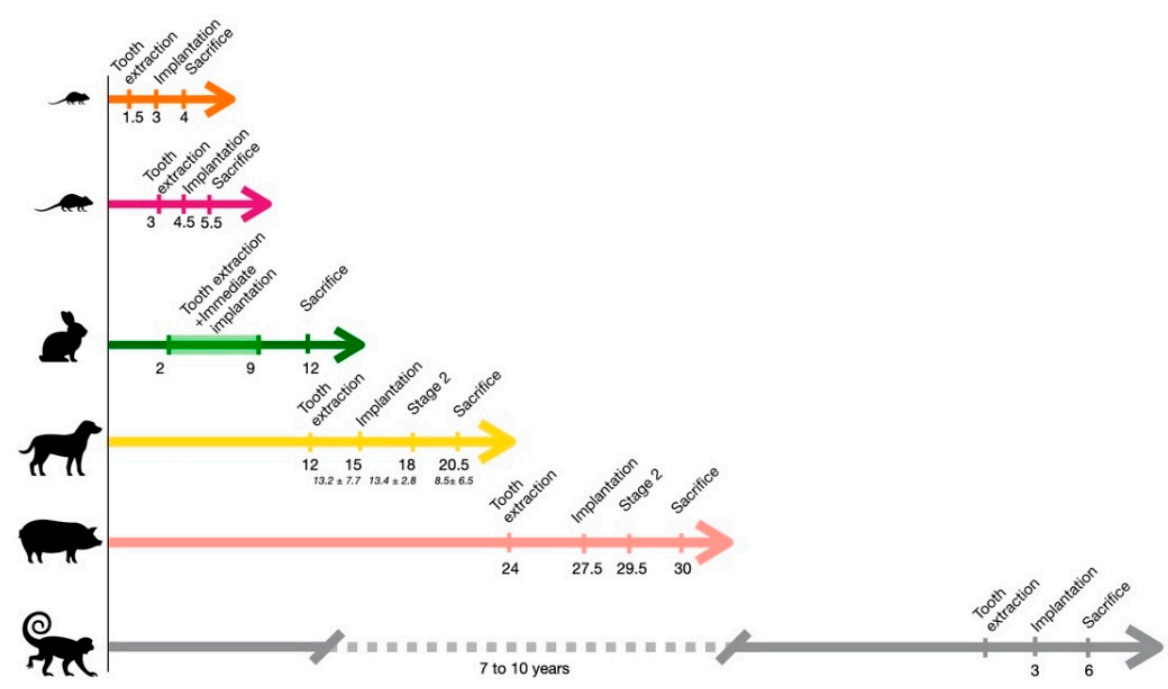

Figure 2. Representative duration of dental implant protocols by type of animal model. Time is expressed in months (unless indicated otherwise) from birth to sacrifice (values for large animals adapted from Schwarz et al. [9]).

Furthermore, for ethical reasons, in addition to costs and housing difficulties, NHPs have almost completely stopped being used [10] in accordance with international legislation, except for the assessment of major innovations or new treatments already validated in another large animal model. Consequently, the number of research studies using NHPs has decreased (Figure 3A) with few articles on dental implant procedures, most published before 2015 (Figure 3B). Pros and cons are summarized in Figure 4.

A

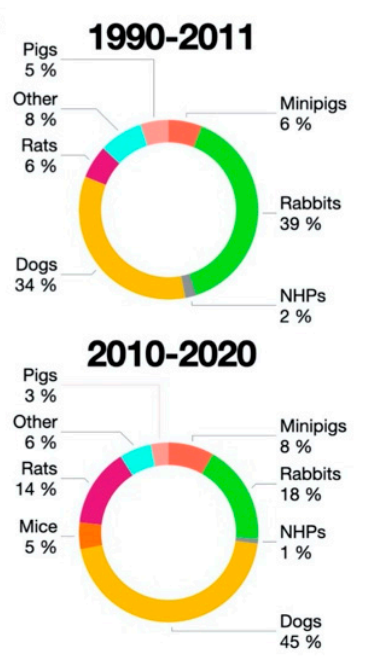

B

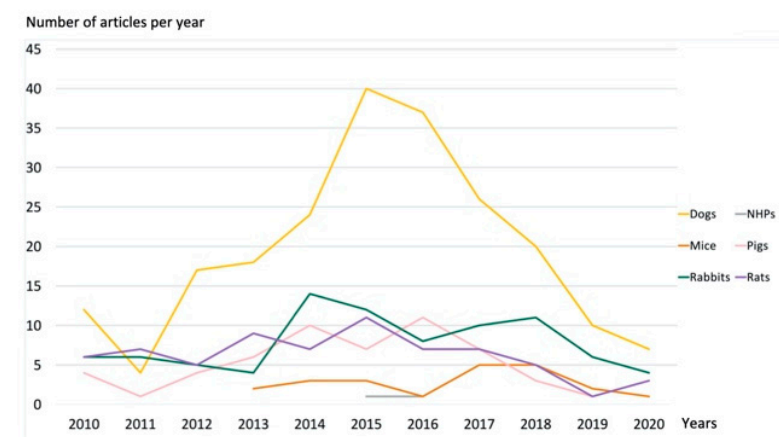

Figure 3. Distribution of animal model studies in implant research (A) from 1990 to 2011 (adapted from Stadlinger et al. [2]) and from 2010 to 2020 (NHP: non-human primate); (B) distribution of publications over the past 10 years. 


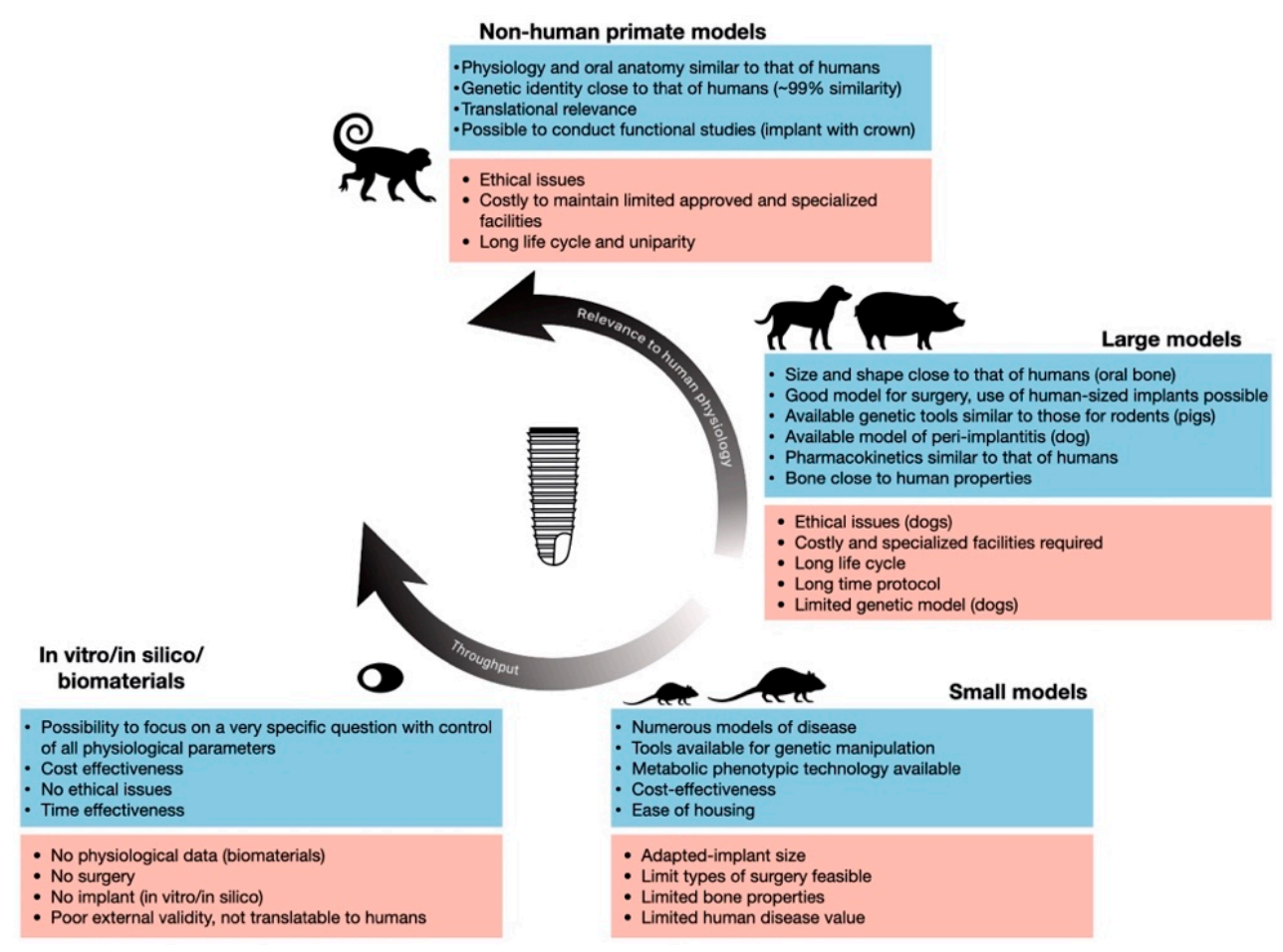

Figure 4. Key advantages and disadvantages of the different types of models used in dental implantology research (adapted from Kleinert et al. [11]).

\subsection{Canine Models}

Before the development of implantology and in contrast to NHPs, dogs were considered the natural model for periodontitis. Indeed, most canines can develop periodontal disease with a conventional transition process from gingivitis to periodontitis [12,13]. This natural periodontitis reproduces human periodontitis from both the microbiological [14] and clinical [10] points of view. Clinically, this model makes it possible to investigate commonly used grading criteria: pocket depth with marginal alveolar bone loss and marginal recessions [10]. Periodontitis severity normally decreases from the first premolar to the first molar [15].

Pros and Cons of the Models

A recent report published by the National Association for Biomedical Research based on the US Food and Drug Administration data has shown that dogs were key in developing 22 out of the 25 drugs most prescribed in the US in 2014 [16,17]. In implantology, successful pre-clinical study designs in dogs have been used to test general approaches and regenerative therapies, such as the use of growth factors and barrier membranes [18]. Advantages of dog models include the ease of management and manipulation before surgery and during postoperative oral hygiene procedures and reducing bias between animals; however, they have the disadvantage of dogs being companion animals with the associated ethical implications [19]. As the use of these models was well established in the periodontal research community, they were naturally transposed to the implantology field $[20,21]$ and validated in peri-implantitis models [22-24]. Such natural periodontal lesions appear after several years which is a disadvantage, but they are usually accelerated with a soft diet and submarginal ligatures [9].

Thanks to this extensive history of use in basic research over more than 40 years, canine models have gained prominence and are now widely used in implantology, having been employed in 215 out of 479 studies reported this last decade (Table A2). Dogs are considered large animal models in implantology and the use of human-sized implants is common [4]. Bones are similar to those of humans in terms of water, organic, volatile inorganic, and ash fractions [25]. In addition, dogs have a mixed microstructure bone with 
secondary osteons mainly in the center of the cortical bone, with plexiform organization on each side [26]. Plexiform bone is characterized by a rapid bone apposition process. In humans, this organization is only found in children during rapid growth to improve mechanical strength against fracture.

There are, however, notable differences in terms of weight and size between dog breeds, in some cases, increasing discrepancies with human bones [19]. Furthermore, the rate of trabecular bone remodeling differs between humans and dogs, and also between bones in the same animal (with bone turnover rates from $12 \%$ for the talus to nearly $200 \%$ for the lumbar vertebral body $[19,27])$. Similar differences have been observed in cortical bone $[19,28]$ and between oral bones, with a bone remodeling rate two-fold higher in the mandible than the maxilla [29]. Aside from age, which affects bone turnover and response to implants [30], this specificity has to be considered for determining the implantation site.

Experiments are usually performed in 1-year-old individuals with full adult dentition but can be performed in dogs up to 2 years of age [31] (Figure 2, Appendix A.2, Table A1). Pros and cons are summarized in Figure 4.

\subsection{Swine Models}

Swine, both pigs and minipigs, is one of the main species used in translational research. Pigs have the advantage of anatomical, physiological, metabolic, and genetic similarities to humans. Bone studies were mostly conducted on porcine models in the 1970s for studies on infectious bone diseases, [32] surgery training and toxicology testing, [33] and researchers rapidly extended this model to the field of implantology in the 1990s [34]. Their use in biomedical research has been growing considerably in recent years as it has come to be considered an optimal model for many human diseases. Pigs are now used in various fields of biomedical research, including genetics [35] and clinical research (e.g., organ transplantation and cancer [36]).

\section{Pros and Cons of the Models}

The use of pig models is justified in dental implantology by the similarities of the periodontium to that of humans both anatomically and physiologically [37]. Indeed, pig bone has a similar Haversian structure to that of humans [38] and also a similar bone mineral density, [25] with minimal differences in minimum diameter and number of lacunae per osteon [39], and bone remodeling rate (1.2-1.5 mL/day in pigs vs. 1.0-1.5 mL/day in humans) [19]. Nonetheless, there are some differences: notably, pigs have a denser trabecular network and a higher bone mass, [40] and the maximum diameter, perimeter, area, and circularity of the osteons also differ [39].

Generally, from a research point of view, commercial breeds of pig, or farm pigs, have multiple disadvantages. First, the development of pigs results in rapid growth rates and excessive bone weight which is a disadvantage compared to other species [6]. Secondly, pigs tend to be difficult to handle due to their potentially aggressive temperament, heavy weight (up to $350 \mathrm{~kg}$ in the case of an adult domestic pig [5]) and high housing costs. Any repetitive procedure, such as oral hygiene maintenance, cannot be carried out without trained technicians [41]. Further, it is difficult to train pigs and postoperative healing may be jeopardized if they can access materials to chew (e.g., metal grid bars) [42]. The breeding of minipigs has resolved some of these issues [43] and has considerably helped to widen the use of pig models.

Minipig models are nowadays a standard tool for dentistry research [4]. There are almost 50 breeds of minipigs available worldwide [44]. As adults, depending on the breed, mini-pigs weigh between only $35 \mathrm{~kg}$ (Göttingen breed) and $95 \mathrm{~kg}$ (Hanford breed) [45], facilitating their housing. They reach sexual maturity early, at 4 to 6 months of age (Table A1). As they result from selective breeding, they are not considered transgenic or genetically modified animals [46] and their physiology and anatomy are not far different from those of conventional pigs [33]. In implantology, both pigs and minipigs show anatomic characteristics close to those of humans, allowing the placement of commonly 
used dental implants (6-10 $\mathrm{mm}$ in length $/ 3$ to $4.8 \mathrm{~mm}$ in diameter) which is a tremendous advantage compared to small animal models [4]. Another major advantage of minipigs is the ability to perform long follow-up with multiple surgical steps [47] and age-related studies [48]. On the other hand, to avoid the costs of breeding, animals are usually ordered from commercial laboratories for each experiment.

The duration of a conventional protocol differs between studies and between pig models (farm pigs versus minipigs) (see Appendix A.3). Pros and cons are summarized in Figure 4.

\subsection{Other Large Animal Models}

Other large animal models have not been widely used in implantology (Table A2). The ovine long-bone model has been mainly used for research on surgical techniques (vertical ridge augmentation [49], drilling procedures [50-52]), and implant surface properties [53]. Overall, in sheep, there have been relatively few studies with differing protocols and objectives. Only one study has been conducted in the mandibular bone to assess the effect of implant coating on a titanium implant [54]. Other large animal models have been tested, such as the sika deer for their antlers [55], and the goat for surgical experimentation [56] and implant osseointegration (mainly in the pelvic region) $[57,58]$.

\subsection{Conclusion on the Use of Large Animal Models in Dental Implant Research}

Nowadays, within the binary "large vs. small animal models" classification (Figure 1), a new level of decisional procedures has emerged regarding study objectives, with the establishment of sub-classes according to species-specific characteristics of each large animal model. Pre-clinical surgical procedures (e.g., sinus or bone augmentation) with human-sized implants on large animals can be categorized (Figure 5):

- NHPs are no longer used in Europe and are only used elsewhere in already accredited procedures. NHP models, particularly the baboon, should be considered a confirmation model reserved for studies on major advances providing substantial added scientific value, already validated in another model.

- $\quad$ Pigs and minipigs are the new pioneers, having replaced dogs in procedures. The minipig appears to be an ideal model for studies of bone regeneration around dental implants when placed at intraoral sites.

- Dogs should only be used when pigs cannot be used to address the question of interest (mainly for compromised oral conditions, sinus surgery, and peri-implantitis procedures). In particular, dog models should be preferentially employed for studies conducted under compromised oral conditions (biofilm).

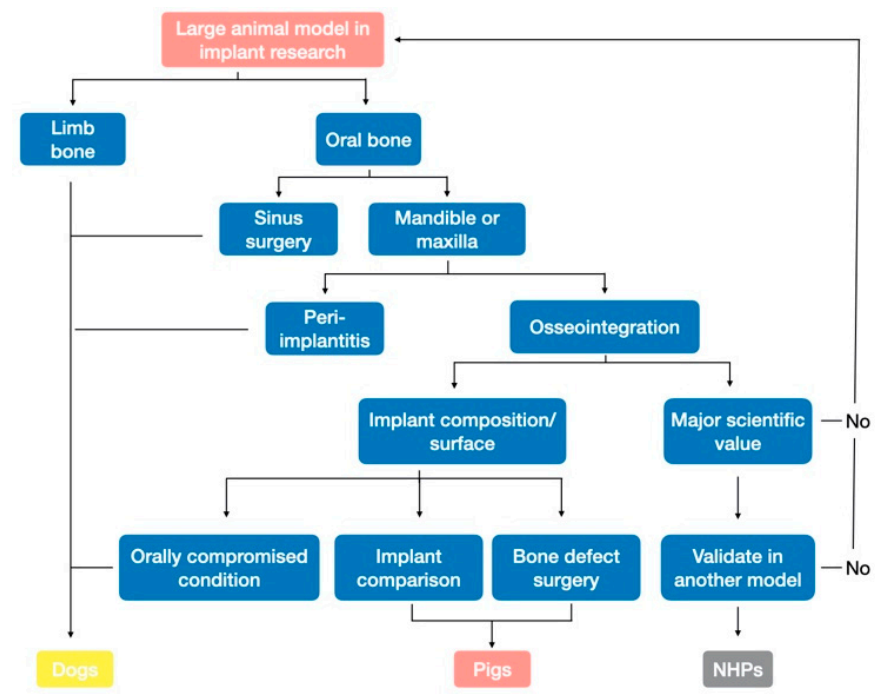

Figure 5. Large animal model selection in dental implant research (NHP: non-human primate). 


\section{Small Animal Models in Implantology}

\subsection{Rabbit Models}

The popularity of these models stems from the work of Sawin et al. in orthopedics in the 1940s, supported by descriptions of rabbit breeding, anatomy, and surgical protocols $[59,60]$. At the end of the last century, approximately $35 \%$ of musculoskeletal research studies were performed using rabbit models [61]. This widespread documentation from biomedical research led to the use of this animal for in-vivo bone studies. In 1997, Mori et al. used a rabbit model to improve our understanding of the physiological process of osseointegration in rabbits with induced osteoporosis [62]. Since then, rabbits have been used intensively, representing $27 \%$ of dental implant research in animals [1]. Interestingly, however, this figure has fallen sharply with just 86 studies (11\%) over the last decade (Figure 3B), reflecting the overall decrease in their use in research [63].

Pros and Cons of the Models

According to the American Rabbit Breeders Association, there are 49 rabbit breeds [64]. Of the various breeds, the New Zealand White rabbit ( 5 to $6 \mathrm{Kg}$ ) is the most commonly chosen for implantology research (Table A1). This species is of particular interest with the advent of transgenic rabbits (for hormone regulation [65], diabetes [66], and osteoporosis [67]). Thanks to its accelerated skeletal maturity (at around 6 months of age) and rapid bone turnover (faster than that in primates), the rabbit is a convenient model for laboratory research [68]. On the other hand, this rapid turnover could introduce a bias in long-term studies, making results difficult to interpret with respect to human biology [19]. Furthermore, the skeleton of the mature rabbit is fragile, representing only about $8 \%$ of its body weight [69]. Histological analysis of compact bone has shown rabbit bone to be one of the most different from humans, with major differences not only in Haversian canals and secondary osteons but also in vascularization $[70,71]$.

Surgical protocols to study osseointegration have been developed in two main areas in rabbits: (i) extra-oral models in long bones (femur and/or tibia) and (ii) oral models (mandible, maxilla, and sinus) (see Appendix A.4). Pros and cons are summarized in Figure 4.

\subsection{Rat Models}

Rats are a good starting point for testing new procedures thanks to the ease of housing and relatively low costs, compared to those of large animal models, as well as the extensive history of their use in scientific experiments [25]. Rat physiology, especially in bone tissue, suggests it would be useful for research in certain areas. The growing rat is a well-known model for evaluating the effects of endocrine, nutritional and environmental factors on peak bone mass but is not appropriate for adult human skeleton studies due to the presence of cellular pathways not present in human adults [72]. Bone mass gain, in parallel with the long bone elongation, mainly occurs during the first 6 months of life [72], though some authors consider that the long bone grows continuously for at least 1 year with a gradual transition from modeling to remodeling with age [73], a transition that does not occur uniformly across bones [74]. Due to this longitudinal bone growth, a margin of at least $1 \mathrm{~mm}$ from the growth plate of the tibia should be left intact if experimentation starts around 10 months of age, an issue to be considered in dental implant studies [74]. Sex and hormones are also key parameters in rat research. At 8 months of age, males were found to have $22 \%$ greater bone width and $33 \%$ greater breaking strength than females in the tibia [75]. The role of hormones has been put to good use in an ovariectomy model. Rats, as for any rodents, do not have natural menopause, but the ablation of the gonad is a good model for artificial menopause [76] and therefore for the analysis of osseointegration in a model of pathological bone. 
Pros and Cons of the Models

For implantology purposes, the size of the rat is a mixed blessing. The lower costs and ease of housing and handling favor the use of this animal. On the other hand, only small human implants can be used, and most of the time, implants need to be adapted.

Two rat breeds are commonly used: (1) Wistar rats (from the Wistar Institute) are one of the oldest and still considered one of the best rat models. By adulthood, they reach $500 \mathrm{~g}$ [77] which places them in the mid-upper range of small laboratory animals. (2) Sprague Dawley rats, developed from Wistar rats, have an adult weight of up to $300 \mathrm{~g}$ [5] and are one of the breeds most widely used in pre-clinical studies [78]. They have been used as a model for osteoporosis, and for analyzing the effects of calcium supplementation on bones [79] (Table A1). Various protocols have been developed in rats depending on the implantation site (see Appendix A.5). The number of research studies using rats has increased during the last decade (Figure 3A) and confirms the scientific interest in this model [80]. Pros and cons are summarized in Figure 4.

\subsection{Mouse Models}

The mouse is the animal most commonly used in laboratory research. It was the first laboratory animal model established for genetic- and aged-related changes in bone [81] and used for full genomic analysis.

Pros and Cons of the Models

Among all mouse strains, C57BL/ 6 is the most commonly used, almost 20,000 papers having been published referring to research using this strain in 2019 [82]. Within the same strain, different sub-strains show notable genetic and phenotypic differences [83]. It is therefore important to determine, when planning a research study, which type of animal is needed.

From a bone point of view, mice have similar growth characteristics to rats, with even more marked size-related advantages and disadvantages. It is therefore inappropriate to carry out an implant study in mice if the same model has been developed in rats. Nonetheless, mice have some characteristics which distinguish them from other laboratory animals.

The main advantage they offer over other small animal models is the existence of numerous knockout and transgenic mice. This factor is even more important with the emergence of new tools to develop genetically engineered mouse models. Transfection or viral vector transduction are routinely applied methods for random DNA integration [84], while the CRISPR-cas9 system for gene editing [85] is an emerging technology that extends the scope of research in this field [86].

In implant studies, this model has been used for a long time but primarily for extraoral approaches due to technical and surgical complications [4], the reason most often mentioned being the difficulty of access due to the mouth size and range of opening of mice. Some authors opted to develop a more accurate model by working on the mouse maxilla [87]. A limitation of this model is the limited cortical bone remodeling and the lack of the Haversian structure in cortical bones. Indeed, rodent long bones are mainly composed of primary bone and a minimal proportion of cancellous bone [6]. The counterpart of this biological issue is the small amount of cancellous bone site for implantation studies [88].

As for rats, protocols are markedly heterogeneous, and it has not been possible to establish a gold standard (See Appendix A.6). Pros and cons are summarized in Figure 4.

\subsection{Conclusion on the Use of Small Animal Models in Dental Implant Research}

Smaller-sized implant models and biocompatibility studies should be performed on small animal models as cell toxicity does not require implant-shaped material (Figure 6). 
- Rabbits should be recommended for biocompatibility studies if large numbers of implants are needed per animal, their availability in large numbers appearing to be the only advantage of this model.

- Other questions should be addressed using rats, which are suitable for biocompatibility and common bone analysis in healthy models.

- Mice are still the best option for human disease models with the existence of numerous knockout and transgenic mice models. Peri-implantitis procedures are also an emerging field in this species.

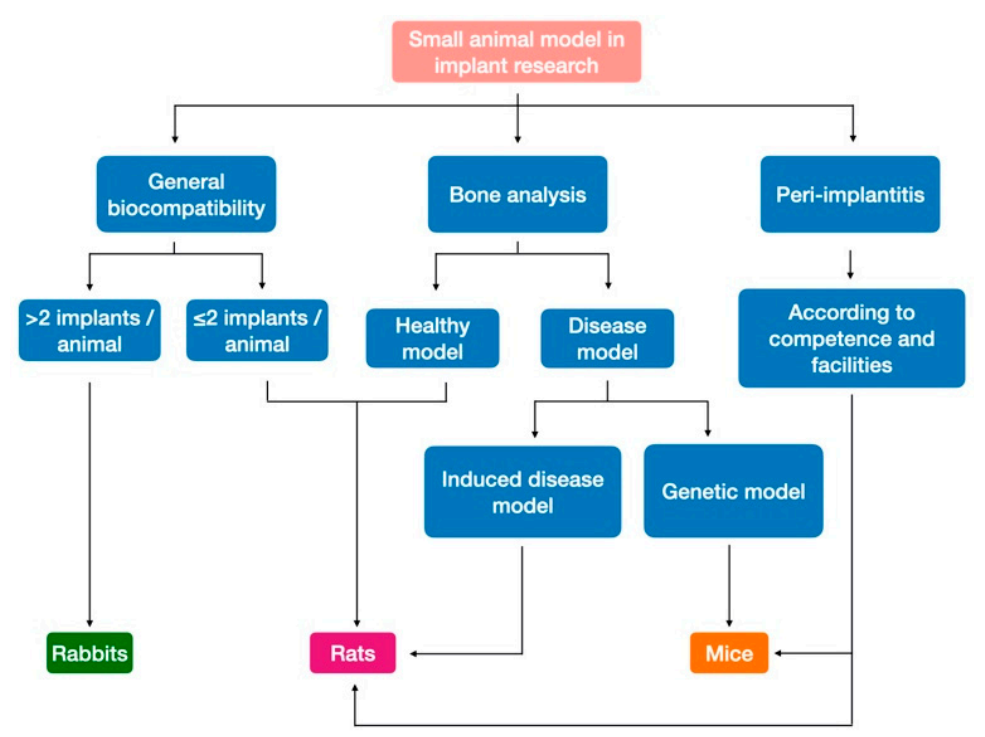

Figure 6. Small animal model selection in dental implant research.

\section{Future Challenges and Strategies}

\subsection{The Outlook for Animal Models}

The framework of the 3Rs re-defined animal model applications in implantology by completely rethinking our way of operating Although in vivo studies remain essential to investigate specific challenges in implantology, in vitro approaches play a leading role in developing protocols.

Overlaying diagrams by model size (small or large) shows that models within each category offer similar characteristics. Interestingly, rating comparable criteria for each model, (i) although mice are small, the mouse model seems to have numerous advantages for implant studies and (ii) in vitro/in silico models and analyses of biomaterial properties are ranked top, highlighting their great potential in the field of dental implantology (Figure 7).

\subsection{Development of Replacement Strategies}

The principles of the 3Rs were developed over 50 years ago, aiming to encourage alternatives to animal testing and improve animal welfare and research quality where the use of animals could not be avoided. 


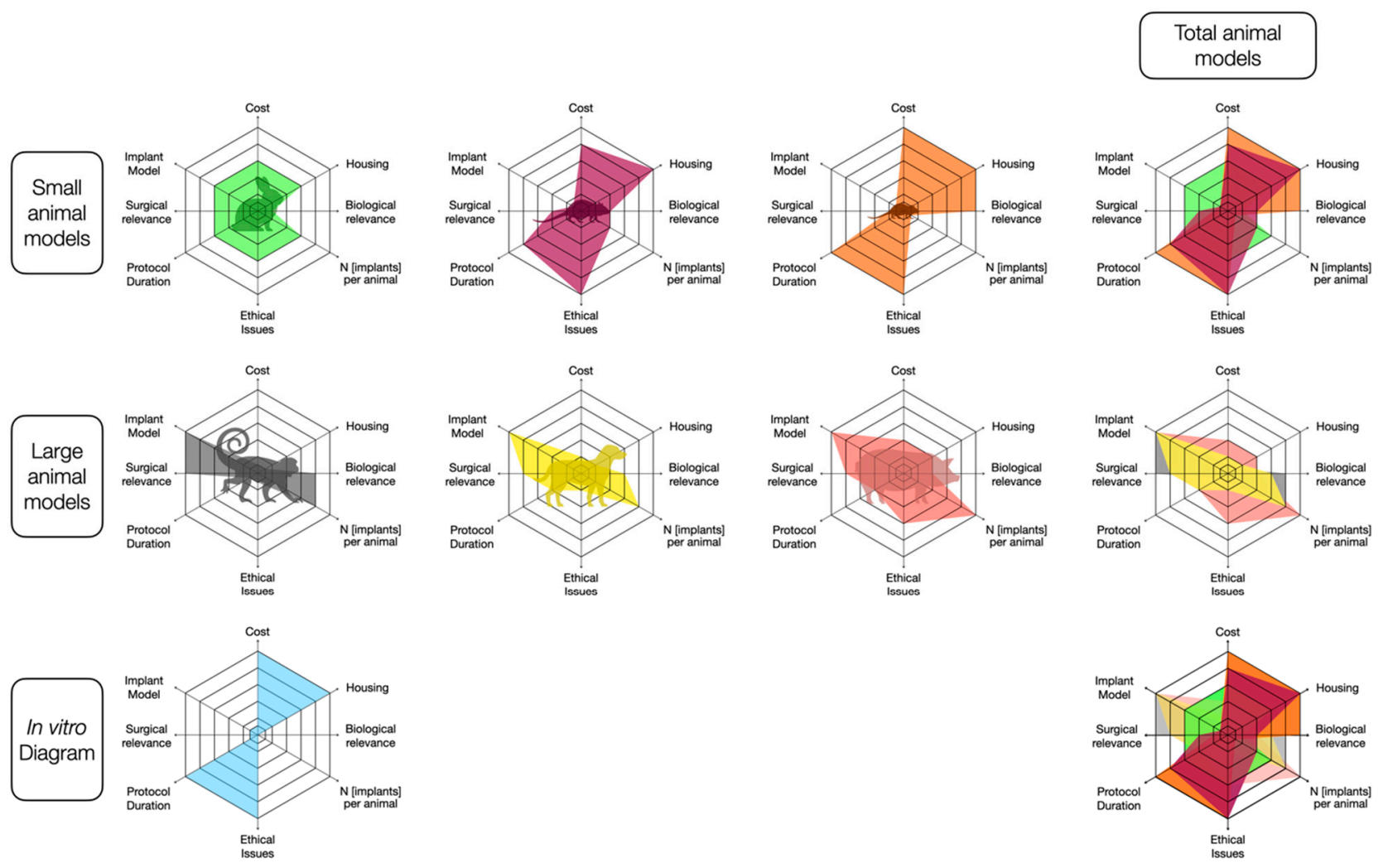

Figure 7. Overall appeal assessed by animal model. Diagram based on key elements of interest in pre-clinical research: cost, housing and husbandry requirements, protocol duration, biological relevance, $\mathrm{N}$ [implants] per animal, ethical issues, surgical relevance, and resemblance to the human implant model. For each criterion, the models were ranked (from best [1, outer line] to worst [6, inner line] (Table A3). Overlaying diagrams by animal size also shows that small and large models have very similar characteristics to others in the same size group. The diagrams indicate that the in vitro/in silico and biomaterials study type was ranked first for four criteria (cost, housing and husbandry requirements, ethical issues, and protocol duration) and last for two criteria (surgical relevance and implant model), as they are not addressed by such studies, while two criteria were not applicable to this last category (biological relevance and number of implants per animal). Comparison with the global diagram shows that the mouse model diagram is the closest to that of the in vitro/in silico/biomaterial models.

\subsubsection{In Vitro Biocompatibility and Cytotoxicity Analyses}

In vitro human or animal cell-based studies on modified surfaces for dental implants allow the assessment of toxicity and characterization of osteoblast adhesion to the implant, or the impact of any added processing steps on the implant surface $[89,90]$. For example, when a new nanoparticle treatment is developed, in vitro studies are needed to test implant treatment viability during cell interaction [91]. Similar studies are needed to test bioactive [92-94] or peptide (e.g., RGD [95]) coatings, or the incorporation of antibiotics [96] or growth factors (e.g., bone morphogenetic proteins [97]).

In vitro studies can also assess the impact of given clinical methods on a device [98]. By applying a procedure directly to the implant, for example, studying the effect of various polishing methods on bacterial colonization [99-101], the need for an animal model can be reduced and it may be easier to focus on the interaction of interest. As titanium is the main material used in dental implant surgery, experiments have mainly focused on titanium powder or titanium disks. For example, in vitro studies showed that some surfaces induce the generation of toxic particles, certain surfaces being more toxic than others to oral epithelial cells [102]. Other materials, such as zirconium implants, have also been tested for cell biocompatibility and mechanical properties [103]. 


\subsubsection{In Vitro Models of Response to Implant and Associated Biofilm}

For more biological issues, in vitro models were developed at the end of the 1990s to assess the possibility of answering simple questions without the use of animals [104,105]. According to Mombelli et al., in vitro models were relevant for studying: (i) the reaction of micro-organisms to the presence of implants, (ii) the reaction of implant-associated micro-organisms to antimicrobial agents, and finally, (iii) the reaction of the host tissues to the presence of implants contaminated with micro-organisms $[105,106]$. In vitro studies have subsequently been applied to the issues of hypersensitivity, and immune and proinflammatory responses [107]. Biofilm assays are also a common in vitro procedure for the analysis of antibiotic resistance. Adapted to implantology, complete implants or titanium chips are used in cell culture in the presence of bacteria, allowing the analysis of bacteria adhesion and biofilm construction. Once the biofilm is stable, chlorhexidine [108] or antibiotics can be added to the medium to observe their performance. In the same process, infected implants can be placed in contact with animal or human cells to study their interaction [106].

\subsubsection{In Vitro Physical and Mechanical Evaluation}

Once biocompatibility and cytotoxicity have been demonstrated, protocols for physical and mechanical testing can assess the resilience to different loads in pre-load models, monitoring numerous variables related to the implant-abutment connection [109], such as force used for screw tightening [110], ability to withstand a long-term load (assessed by direct strength testing) [111], and chewing cycle (simulated by an artificial mouth) [112,113]. Further, esthetic comparisons can be made in terms of abutment titanium visibility [114].

Finally, in vitro rather than animal models should be used to study the improvement and/or development of future technologies, such as computer-guided navigation for implant placement [115], laser procedures [116], or comparisons between different scanning methods [117].

The 3Rs are now widely embedded in national and international legislation and regulations on the use of animals in scientific procedures. Following these principles, before conducting an in vivo study, it has to be considered whether it is possible to replace the use of animals with alternative methods. Indeed, in implantology, before any in vivo test, in vitro analysis is essential for implant development. Before choosing which animal is needed for a procedure, the first decision is whether we can avoid using animals at all (Figure 8).

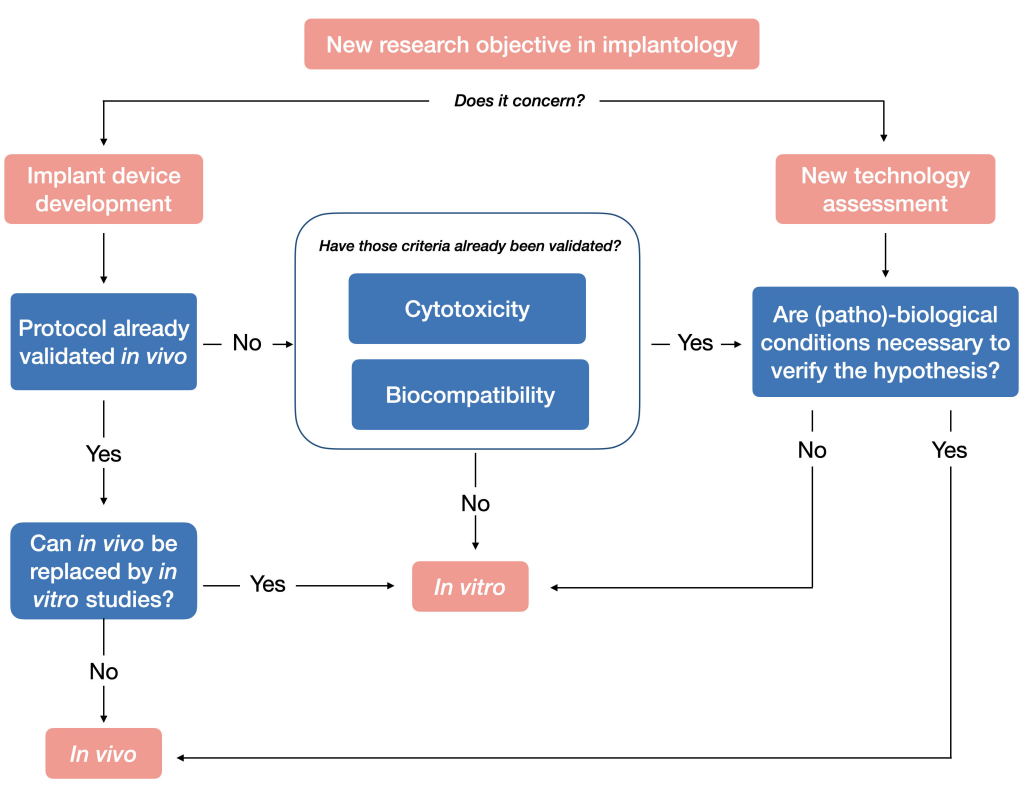

Figure 8. Research protocol selection in dental implant research: in vivo vs. in vitro. 


\section{Conclusions}

Biological advances in large animals have narrowed the gap between large and small animal model applications, as it is now possible to perform genetic analysis in dogs while it was previously only possible in small animal models, and at the same time, technological advances have enabled reductions in instrument size, and therefore the manufacturing of small implants is compatible with mouse size. The distinctions between these two groups are small, but the specificities of dental implant models allow rational decisions concerning their use to maximize scientific impact and benefits.

Last but not least, nowadays any decision-making process dealing with animal sacrifice in research raises the key question of its scientific necessity, especially in the development of dental implant protocols dealing with elective surgeries (Figure 4). Considerable efforts have been recently made to replace animal studies with in vitro studies, which enable mechanical and physical characterization of dental implants. Thus, when the question of the use of animals in implant surgery research nowadays arises, another question must always follow: "can we do otherwise"?

Funding: This study was funded by the Agence Nationale de la Recherche (grant Hyposkel 18-CE140018-01); and Fondation pour la Recherche Médicale (grant DGE20111123012); Nicolas Banc-Sylvestre was supported by the Fondation pour la Recherche Médicale (grant FDM201906008500).

Acknowledgments: The authors thank the support of the Agence Nationale de la Recherche and Fondation pour la Recherche Médicale.

Conflicts of Interest: The authors declare no conflict of interest.

\section{Appendix A}

\section{Appendix A.1. Research in Non-Human Primates}

In 2010, the European Parliament issued a directive which is still in force: "The use of non-human primates should be permitted only in those biomedical areas essential for the benefit of human beings, for which no other alternative replacement methods are yet available" [118].

Furthermore, there are risks associated with handling due to the possibility of zoonotic disease transmission $[41,119]$ but also biological and behavioral responses due to stressors such as separation from their familial environment [120].

The duration of a conventional protocol is around 6 to 9 months with a first healing time of 3 months after tooth extraction and 3 to 6 months after implantation (Figure 2). Protocols are usually performed on adult animals, from 7 to 10 years old, this allowing the use of human-sized implants (Figure 5). Laboratory breeding and reproduction are therefore not feasible, and animals are acquired for the protocol. Such studies have investigated the healing process after sinus floor elevation [121-123], improvements of analysis techniques [124], and clinical questions concerning soft-tissue response around combined tooth-implant-supported prostheses [125,126]. Old World monkeys such as baboons, mandrills, and macaques are preferred, as their long bones have a dense Haversian structure, with thin layers of endosteal and periosteal bone [127]. For anatomical reasons, the use of Rhesus macaques has to be avoided, their adult size and weight (6.5 to $12 \mathrm{~kg}$ vs. $21.5 \mathrm{~kg}$ for male baboon) [5] being too small to be considered a "large animal model".

Summary: In accordance with international legislation, NHPs should no longer be used except for the assessment of major innovations or new treatments already validated in another large animal model (Figure 5).

\section{Appendix A.2. Research in Canine Models}

The most commonly used dog breed is the beagle due to the ease of care. Its mean adult weight is around $16 \mathrm{~kg}$ [5] allowing the use of human-sized implants. For this type of study, all animals are acquired from accredited laboratories. Mainly carried out in long bones in the past, protocols have now been developed for oral bone models which 
have more appropriate characteristics for the analysis of osseointegration. Similarly, periimplantitis has been successfully transposed to oral implant studies, facilitating the use of oral bone models (Table A1).

The duration of a conventional protocol is slightly shorter than in NHPs, with a first phase of 3 months after tooth extraction and 2 to 3 months of implant healing (Figure 2).

Table A1. Summary of species characteristics and use in implant protocols.

\begin{tabular}{|c|c|c|c|c|c|c|}
\hline & $\begin{array}{l}\text { Non-Human } \\
\text { Primates }\end{array}$ & Pigs & Canines & Rabbits & Rats & Mice \\
\hline $\begin{array}{l}\text { Species most } \\
\text { frequently used }\end{array}$ & $\begin{array}{l}\text { Baboon, mandrill } \\
\text { and macaques }\end{array}$ & $\begin{array}{l}\text { Pigs: Domestic pigs } \\
\text { Minipigs: Hanford } \\
\text { of Göttingen breed }\end{array}$ & Beagle & $\begin{array}{c}\text { New Zealand White } \\
\text { rabbit }\end{array}$ & $\begin{array}{l}\text { Wistar rats, Sprague } \\
\text { Dawley rats }\end{array}$ & C57 Black/ 6 \\
\hline Age of use & 7 to 10 years old & 2 to 3 years old & 1 to 2 years old & 6 to 9 months old & 2 to 3 months old & 8 weeks old \\
\hline $\begin{array}{l}\text { Protocol } \\
\text { duration }\end{array}$ & 6 to 9 months & 12 months & 5 months & $\begin{array}{l}2 \text { to } 4 \text { weeks (long } \\
\text { bone) Up to } 3 \\
\text { months (oral bone) }\end{array}$ & $\begin{array}{l}2 \text { to } 6 \text { weeks (long } \\
\text { bone) } 2.5 \\
\text { months(oral bone) }\end{array}$ & $\begin{array}{l}4 \text { weeks (long bone) } 2 \text { to } \\
3 \text { months (oral bone) }\end{array}$ \\
\hline Weight & $21.5 \mathrm{~kg}$ & $\begin{array}{c}\text { Pig: } 350 \mathrm{~kg} \\
\text { Mini-Pig: } 35 \text { to } 95 \\
\text { kg }\end{array}$ & $15 \mathrm{~kg}$ & 5 to $6 \mathrm{~kg}$ & $\begin{array}{l}\text { Sprague dawley: } 70 \\
\text { to } 300 \mathrm{~g} \text { Wistar rats: } \\
\text { up to } 500 \mathrm{~g}\end{array}$ & $30 \mathrm{~g}$ \\
\hline Implant size & Human-sized & Human-sized & Human-sized & $\begin{array}{l}\text { Human-sized } \\
\text { Adapted implant }\end{array}$ & $\begin{array}{l}\text { Adapted implant: } \\
1.5 \mathrm{~mm} \text { diameter, } \\
2.5 \mathrm{~mm} \text { length }\end{array}$ & $\begin{array}{l}\text { Adapted implant: } 1 \mathrm{~mm} \\
\text { diameter, } 2 \text { to } 3 \mathrm{~mm} \\
\text { length (long bone) } 0.6 \\
\text { mm diameter, } 2 \mathrm{~mm} \\
\text { length (maxilla) }\end{array}$ \\
\hline Trend & Falling into disuse & $\begin{array}{l}\text { Any study related } \\
\text { to implant surgery } \\
\text { under healthy } \\
\text { conditions }\end{array}$ & $\begin{array}{l}\text { Peri-implantitis, } \\
\text { sinus and genetic } \\
\text { studies }\end{array}$ & Falling into disuse & $\begin{array}{c}\text { Systemic conditions } \\
\text { (diabetes, } \\
\text { hormones), poor } \\
\text { bone quality } \\
\text { models, ease of } \\
\text { breed and use }\end{array}$ & $\begin{array}{l}\text { Genetic studies, } \\
\text { knock-out protocols, } \\
\text { peri-implantitis }\end{array}$ \\
\hline
\end{tabular}

\section{Appendix A.2.1. Long Bone Models}

To evaluate implant osseointegration, dental implants were placed in dog leg bones, but this is rare nowadays, less than 20 studies having been reported over the past 10 years (Table A2).

Despite an obvious bias of studying implants loaded on a quadrupedal gait model, protocols involving implant placement on limbs allow the use of a large number of implants, thus reducing the sample size (in one study, up to 75 implants having been tested in the radius of just 6 dogs [128]). Though front limbs can also be used, [128] most of the time both tibias are used, as they offer a large quantity of bone. For this kind of study, implants $3.75 \mathrm{~mm}$ in diameter and $10 \mathrm{~mm}$ in length are the most common, two to three implants being used per tibia [129]. The large amount of bone available allows the creation of surgically created defects to analyze bone regeneration associated with dental implants. Properties of membranes [129] or new grafting compounds [130] have been tested. New implant devices such as implant extenders have also been tested before clinical use [131]. The proximal tibia is commonly used for drilling protocols, to test the impact of drilling in early stages of osseointegration and implant stability [132-137], different implant surfaces [138-142], and biomechanical properties (insertion torque [133], response to compressive stress [143]). 
Table A2. Distribution of implant location by animal and year over the past 10 years based on research articles in MEDLINE, including all experimental implant studies on animals.

\begin{tabular}{|c|c|c|c|c|c|c|c|c|c|c|c|c|c|}
\hline & & 2010 & 2011 & 2012 & 2013 & 2014 & 2015 & 2016 & 2017 & 2018 & 2019 & 2020 & Sum \\
\hline \multirow[t]{3}{*}{ Canines } & & 12 & 4 & 17 & 18 & 24 & 40 & 37 & 26 & 20 & 10 & 7 & 215 \\
\hline & Long bone & & 1 & 5 & 3 & 2 & 3 & 2 & 1 & 2 & & & 19 \\
\hline & Oral bone & 12 & 3 & 12 & 15 & 22 & 37 & 35 & 25 & 18 & 10 & 7 & 196 \\
\hline \multirow{2}{*}{$\begin{array}{l}\text { Non-human } \\
\text { primates }\end{array}$} & & 1 & & 1 & & & 1 & 1 & & & & & 4 \\
\hline & Oral bone & 1 & & 1 & & & 1 & 1 & & & & & 4 \\
\hline \multirow{4}{*}{ Mice } & & 1 & & & 2 & 3 & 3 & 1 & 5 & 5 & 2 & 1 & 23 \\
\hline & Long bone & 1 & & & 1 & & 1 & & 1 & 1 & 1 & 1 & 7 \\
\hline & Oral bone & & & & 1 & 2 & 2 & 1 & 4 & 4 & 1 & & 15 \\
\hline & Other & & & & & 1 & & & & & & & 1 \\
\hline \multirow[t]{4}{*}{ Pigs } & & 4 & 1 & 4 & 6 & 10 & 7 & 11 & 7 & 3 & 1 & & 54 \\
\hline & Long bone & & & & & & 1 & 1 & 2 & & & & 4 \\
\hline & Oral bone & 4 & 1 & 3 & 2 & 9 & 4 & 10 & 2 & 3 & & & 38 \\
\hline & Skull & & & 1 & 4 & 1 & 2 & & 3 & & 1 & & 12 \\
\hline \multirow[t]{4}{*}{ Rabbits } & & 6 & 6 & 5 & 4 & 14 & 12 & 8 & 10 & 11 & 6 & 4 & 86 \\
\hline & Long bone & 6 & 6 & 5 & 4 & 11 & 9 & 6 & 10 & 9 & 4 & 3 & 73 \\
\hline & Oral bone & & & & & 3 & 2 & 2 & & 2 & 2 & 1 & 12 \\
\hline & Skull & & & & & & 1 & & & & & & 1 \\
\hline \multirow[t]{4}{*}{ Rats } & & 6 & 7 & 5 & 9 & 7 & 11 & 7 & 7 & 5 & 1 & 3 & 68 \\
\hline & Long bone & 3 & 5 & 4 & 7 & 4 & 9 & 6 & 6 & 4 & 1 & 1 & 50 \\
\hline & Oral bone & 3 & 2 & & 2 & 1 & 2 & 1 & 1 & 1 & & 2 & 15 \\
\hline & Skull & & & 1 & & 2 & & & & & & & 3 \\
\hline \multirow[t]{4}{*}{ Other } & & 3 & 2 & & 2 & 5 & 3 & 4 & 2 & 6 & 1 & & 28 \\
\hline & Long bone & 2 & 1 & & 1 & 2 & 2 & 2 & 1 & 1 & & & 12 \\
\hline & Oral bone & & & & & 3 & & 2 & 1 & 2 & & & 8 \\
\hline & Other & 1 & 1 & & 1 & & 1 & & & 3 & 1 & & 8 \\
\hline Sum & & 33 & 20 & 32 & 41 & 63 & 77 & 69 & 57 & 50 & 21 & 15 & 478 \\
\hline
\end{tabular}

Appendix A.2.2. Oral Bone Models

Thanks to anatomical similarities, oral bones have been intensively used for research on surgical techniques (Table A2).

- Studies in the maxilla: Rehabilitation of the posterior area is still challenging in clinical practice. Due to sinus pneumatization, the use of small implants versus sinus augmentation is a routine clinical question. The main advantage of the maxillary bone in dogs is the possibility to perform sinus grafting or sinus augmentation procedures. The model is now well established [144] and provides data on, for example, the effect of different depth implant penetration [145], utility of bone grafts [146], and the effect of new materials such as platelet-rich fibrin [147] which inform clinical decision making. Guided bone regeneration substitutes have been tested for augmentation at periimplant defects to assess the biocompatibility and efficiency of new materials [148], membranes [149], and different implant compositions [150]. The anterior area has also been used to test ridge expansion. This type of surgery can be followed by vertical and horizontal resorption of the bony wall. As histological measurements are not possible in humans for ethical reasons, the performance of such techniques in the dog maxilla has made it possible to investigate the healing process and bone remodeling $[151,152]$.

- Studies in the mandible: Healing patterns of the mandible, both of the bone $[31,153]$ and soft tissue compartment, are now well characterized [154-157]. As a result, new techniques have been developed to standardize or even to automate [158] osseointegration analysis. New robotization tools have been developed for biomechanical testing in parallel with 3D modeling [159]. Combined technologies, like the overlaying 
of micro-computed tomography and STL images of an implant, have been developed to analyze hard and soft tissue volume [160].

- Successfully applied to the mandible, conventional protocols have provided clues to answering other clinical questions concerning issues such as the importance of the vertical position [161-163], the implant-crown ratio [164], and implantation in residual roots [165]. Drilling protocols with new techniques [166], sizes [167] or speeds [168] have been analyzed. New surgical methods, like the socket-shield technique $[169,170]$, bone-ring technique [171,172], flapless protocols, and ridge augmentation have improved our understanding of peri-implant tissue healing. The influence of immediate/delayed implant placement on the peri-implant bone [173] and soft-tissue [174] formation has been well documented [175,176]. Post-extraction socket healing, with or without implants [177], has been tested, allowing the basic protocol to be modified to prevent dehiscence [178] or manage the jumping distance between implant and vestibular bone [179]. Bone response to biomechanical loading over time [180,181] or compressive stress [143], excessive loading [182], or lateral force [183] has been studied.

- Biomaterials is a major field of implant research in dogs, especially for tissue augmentation with membranes [184-186], xenografts (DBBM [187-190]), allografts [191], or alloplastics [18,192], but also biotherapeutic proteins (rhBMP-2) [193-196], progenitor cells [197], and stem-cells [198,199], and the use of platelet-rich fibrin [200-202].

- Studies in the mandible have also allowed comparisons between implants. The mandible is large enough to test different implant systems [203], as well as implants with different shapes [204,205], lengths [206], surfaces, and grooves [207-209]. The race to find the best alloy, or surface finish, is still open. New materials like zirconium [210], PEEK [211], tentalum [212], and titanium alloys [213] have also been used to enhance osseointegration. Implant surface properties is a field that attracts the attention of many researchers. Old techniques have been improved with the addition of molecules like magnesium [214], plasma projection [215], or chemical treatment [216] and new techniques have been developed with nanocoatings [217] or biofunctionalization [218]. Comparisons have been made between implants with differing abutment shape [219,220], composition [221,222], or microstructure, [223] and different protocols, e.g., platform switching [224,225], have been tested to support the best peri-implant tissue healing.

- Finally, only a few articles were found combining implants and drugs. Pilot studies have been performed to test topical use of implant surface treatments with melatonin coating or vitamin D $[226,227]$ and the efficacy of mouth rinses for prevention of peri-implant mucositis and peri-implantitis, and more recently, the impact of hyperbaric oxygen on tissue healing was analyzed [228]. From a systemic point of view, vaccines have been developed seeking to prevent alveolar bone loss in peri-implantitis $[229,230]$.

- Contribution of peri-implantitis studies in dog models to implantology: A specific strength of this model is the ability to perform periodontitis and peri-implantitis protocols, the dog being the large animal model most widely used in periodontitis studies [231]. A new line of research is the characterization of the peri-implantitis microbiota and changes therein during and after ligature placement, as well as after treatment [232-235]. Silk and cotton ligatures have been extensively used to initiate plaque formation and therefore an inflammatory process in gingival tissues [236]. New protocols have been developed to accelerate or exacerbate the inflammatory process [237]. For their flexibility and ease of handling, stainless steel ligatures have been proposed to replace soft ligatures which can be tricky to place and retain on the implantation site in the long term. Immediate induction of peri-implantitis has shown similar results to conventional methods with a shorter 6-month protocol [238].

- A better understanding has been obtained of implants' susceptibility to bacterial contamination depending on the surface condition or composition [239] and char- 
acteristics [240-242] and tools have been developed to treat them mechanically (TiBrush [243], ER:YAG laser [243]) or with drugs (antimicrobials [244], chlorexidine [245], mouth rinse [246], or even plasma [247]) and to reconstruct bone tissue lost [248].

Summary: A natural tendency to develop periodontal disease and the ease of reproducing peri-implantitis make the dog a strong model for dental implant research. Nonetheless, animal care regulations and husbandry requirements (exercise, need for environmental enrichment) [249] limit the use of dog models to research for which other animal models cannot be used (e.g., large models of peri-implantitis, microbiological studies) (Figure 5, Table A3). Interestingly, the emergence of new evidence demonstrating the similarity of dogs and humans in rare diseases [250] widens the field of application of this model, building a dual model with advantages of both large models (clinically relevant) and small models (genetic disorders).

Table A3. Overall appeal weighted by animal model. Rankings for each criterion from 1 to 6 .

\begin{tabular}{|c|c|c|c|c|c|c|c|c|c|}
\hline Models & Cost & $\begin{array}{l}\text { Housing/Husbandry } \\
\text { Requirement }\end{array}$ & $\begin{array}{l}\text { Biological } \\
\text { Interest }\end{array}$ & $\begin{array}{c}\text { N per } \\
\text { Animal }\end{array}$ & $\begin{array}{l}\text { Ethical } \\
\text { Issues }\end{array}$ & $\begin{array}{l}\text { Protocol } \\
\text { Duration }\end{array}$ & $\begin{array}{l}\text { Surgical } \\
\text { Relevance }\end{array}$ & $\begin{array}{l}\text { Implant } \\
\text { Model }\end{array}$ & Total \\
\hline Mice & 1 & 1 & 1 & 5 & 1 & 1 & 5 & 6 & 21 \\
\hline Rats & 2 & 1 & 4 & 4 & 2 & 2 & 4 & 6 & 25 \\
\hline Rabbits & 3 & 3 & 6 & 3 & 3 & 3 & 3 & 3 & 27 \\
\hline Pigs & 4 & 4 & 4 & 1 & 4 & 5 & 2 & 1 & 25 \\
\hline Canines & 5 & 5 & 3 & 2 & 5 & 4 & 2 & 1 & 27 \\
\hline Non-human primates & 6 & 6 & 2 & 2 & 6 & 6 & 1 & 1 & 34 \\
\hline $\begin{array}{c}\text { In vitro/in } \\
\text { silico/biomaterials }\end{array}$ & 1 & 1 & - & - & 1 & 1 & 7 & 7 & / \\
\hline
\end{tabular}

\section{Appendix A.3. Research in Pig Models}

Usually, 2- to 3-year-old animals [250] are used for implant insertion 3.5 months after tooth extraction and analysis 8.5 weeks after implantation, if a second stage is needed (Figure 2). Due to the substantial bone thickness and the presence of numerous adequate sites in the oral region, tibias have only been used in a few studies. Similarly, several protocols were developed in the skull (frontal bone or calvaria) but have now mainly been transposed to oral bone. The large amount of bone in the maxilla and mandible allows the use of several implants in a single protocol, and the performance of implant surgery in bone with more appropriate properties.

\section{Appendix A.3.1. Oral Bone Models}

Due to substantial oral bone thickness and the presence of other more appropriate areas, tibias have only been used in a few studies (Table A2). On the other hand, they allow researchers to (i) insert multiple implants in the same bone (up to 6 per tibia [251,252]), given their large surface area, and (ii) use a split design with both tibias, reducing the number of animals required.

Implant surgery can be performed following human protocols and using human-sized implants (mean of $4 \mathrm{~mm}$ in diameter and $11 \mathrm{~mm}$ in length). Therefore, primary stability, implant stability quotient, and removal torque can be measured in the same way as in clinical practice [252]. This model can also be used to test the viability and mechanical properties of new implants [253] or compare different models [251,254].

\section{Appendix A.3.2. Skull Bone Models}

Reports have been found of several studies the skull (frontal [255] or in calvaria [256]). These models allow implant osseointegration and healing without mastication constraints or tongue movement and are suitable for multiple-step protocols [257] or surgery with large instruments. This area also permits the implantation of up to 12 devices in the same animal. Nonetheless, the length of the implant has to be carefully selected to avoid brain damage. In terms of protocols, the scope for research is similar to that for the mandible: surface conditioning [258-261], implant composition [262], implant macro-design [263] 
and abutment [264], pull-out strength [265], and bone augmentation with [256] or without grafts [266], but also diseases (e.g., diabetes [267]).

\section{Appendix A.3.3. Oral Bone Models}

Most pig oral bone models use either the maxilla or mandible for implantology research. Not surprisingly, the maxillary sinus has been poorly studied due to its position (distal to the last molar) making it difficult to access. The maxilla and mandible can be used in the same protocol, often with teeth extractions in all four quadrants to maximize the number of implants [268]. In systemic disease processes, it seems that the pig model is poorly suited and only used for obesity/metabolic syndrome and/or diabetes [269-271]. Peri-implantitis also appears to have been poorly investigated [272].

A range of surgical techniques can be performed, such as (i) site preparation with different osteotomies [273], (ii) flap procedures [274,275], or (iii) bone surgery with osteodistraction [276], creation of bone defects [277], and bone grafting [271,278,279]. Biomaterials such as scaffold [280] and disc-shaped matrices for vertical bone regeneration [254,280] have been tested in pigs prior to use in human surgery. Biological coating functionalization with chondroitin sulfate and sulfated hyaluronan with collagen molecules [281-283] is often tested on this model, avoiding the process of miniaturization of a new model to be put on the market.

In oral bones, implants are almost always placed in a socket or healed site after tooth extraction [284]. There are numerous protocols for healing time (ranging from 9 weeks [285] to 8 months [273]), with a mean time of 3-4 months after tooth extraction. Notably, 3 to 4 implants can be anchored per quadrant [284] with human or human-like implants $4 \mathrm{~mm}$ in diameter and $11 \mathrm{~mm}$ in length [286].

As for the tibia, the oral model may be useful for histological analyses such as cytotoxicity and viability of new compositions [287-290] but also for assessments on 1:1 scale models of mechanical properties [47,268,291], stress distribution [287,288], and the effects of different implant and abutment shapes [264,284,292-295]. Thanks to pigs having similar bone properties to those of humans, resistance to insertion [273] or removal torque can be measured during [296] or after healing [268]. It is possible to perform classical analysis such as measurement of bone area [273], marginal bone level [273], crestal bone loss [275], resonance frequency [273], or implant stability quotient [297]. However, the main reason for selecting this site is almost always its suitability for bone-to-implant contact analysis $[273,281,282,286,289,290,294]$. This model is also used to assess the accuracy of new techniques, such as ultrasound imaging [298], comparison of intra-oral and cone beam computed tomography [299,300], magnetic resonance imaging [301], and resonance frequency analysis [302]. In addition, it can be used to investigate not only bone but also soft tissues [295] as in immunohistochemical analysis of blood vessels in peri-implant mucosa [274], cell quantification, and fiber orientation [292], or pangenomic gene-expression analysis [293] of implant tissues.

Summary: Supported by a strong history of use, pig oral bone models are suitable for pre-clinical studies, allowing the testing of different implant surface properties or surgical procedures under physiological conditions. The benefits of minipigs in terms of costs and ease of housing make them the model of choice, overcoming the limitations of other large animal models (Figure 7).

\section{Appendix A.4. Research in Rabbit Models}

Experiments are usually shorter than those in large animal models: (i) as previously described, bone maturity occurs at around 6 months of age, and hence, protocols use rabbits from 6 to 9 months of age, (ii) surgery is mainly performed in long bones, and hence, no healing time is needed, unlike protocols involving tooth extraction, and (iii) bone healing is faster. Protocols can stop 2 to 4 weeks after implantation for bone-to-implant contact analysis (Figure 2). 
Appendix A.4.1. Long Bone Models

The great majority of studies in rabbits correspond to long bone experiments $(69 / 86)$, with $50 / 69$ on the tibia and 19/69 on the femur (Table A2).

- Protocols using the tibia: The anatomy and histology of rabbit tibia are well known, the rabbit being used for the first attempt to develop an animal model of osteomyelitis [303] for bone fracture analysis [304]. Numerous research protocols have been developed on the tibia, as the relatively good volume accessible has allowed analysis of as many as 112 implants in 28 rabbits in one study [305]. In this area, 3- to 4-mm diameter implants can be used with lengths of up to $7 \mathrm{~mm}$ [306]. Rabbit tibia has been widely used to analyze the osseointegration of zirconia implants [307], titaniumzirconium implants [308], implants coated with calcium carbonate [309], and implants with surface modifications [306,310,311].Bilateral procedures are generally described including (i) two implants per animal with one implant in each tibia [311]; (ii) four implants per animal with two implants in each [312] or (iii) six implants per animal with three implants per tibia $[313,314]$. The metaphysis and diaphysis of the bone can be used. Thanks to fast healing, osseointegration can be analyzed 1 month after implantation [312]. The tibia has also been used for drilling studies seeking to improve implant stability [315] with drilling speed [316] or drill diameter and implant torque [312] analysis. The large volume of the tibia and ease of surgery have allowed this bone to be used for the creation of peri-implant defects [317] and the use of a bone substitute model [318] and spacers [319], as well as for pathophysiological purposes, mainly for reduced bone models (osteopenic or osteoporotic conditions) [320-323]. Environmental parameters have been investigated in contexts such as a high-fat diet [324] and irradiation [325].

- Protocols using the femur: the femoral bone has been chosen by researchers for many reasons: Easy access and the small amount of soft tissue [326]. Rabbit long bones are composed of $70-80 \%$ compact bone [68], allowing good implant stability.

- The femur is thicker than the tibia and the medullary space is large [326], allowing multiple implant fixations [63]. Experiments can also be performed on both sides of the knee (distal part of the femur and proximal part of the tibia) [327]. The disadvantages of this model are related to the general differences between humans and rabbits as mentioned above. In particular, rabbit long bones show a distinctive physiological variability of the bone architecture with a longitudinal vascular pattern [26]. Another point to consider is the age of the animal. Indeed, due to endosteal bone remodeling, the bone shows cortical thinning and an increase in bone marrow volume by as much as $24 \%$ with age [328]. It has also been reported that rabbit bone marrow contains a significant proportion of adipose tissue [5], a characteristic not present in the oral cavity in humans, and this reduces the usefulness of the model.

\section{Appendix A.4.2. Skull Bone Models}

For the calvaria, only one study has been found. It sought to analyze the influence of nonsteroidal anti-inflammatory drugs on osseointegration of dental implants in the calvaria [329]. The model found no significant differences in the use of this type of drug and only one rabbit out of the 19 used died in the postoperative period.

\section{Appendix A.4.3. Oral Bone Models}

The rabbit skull is mainly composed of spongy bone and contains wide spaces [69]. The mandible is formed by two symmetrical bones joined by a fibrous or fibrocartilaginous symphysis. As for humans, two parts can be described: (i) the horizontal part, which houses the teeth, and (ii) the vertical posterior part, called the ramus. The maxilla is also formed by two bones fused on the sagittal line. The dental formula of the rabbit is: two pairs of incisors on the maxilla and one on the mandible; no canines; three pairs of premolars on the maxilla and two on the mandible; and two to three pairs of molars on the maxilla and three on the mandible. The total number of teeth ranges from 26 to 
28 [69]. Rabbit incisors grow continuously [330], which is of great interest for longitudinal mineralization studies [331].

As previously described, oral bone, in addition to the obvious difficulty of access due to the small mouth opening, has a poor cortical/spongy bone ratio with mainly spongy bone and wide spaces. There is a paucity of literature in this area and the models seem to be avoided by researchers (Table A1). Out of the 86 studies, 12 were performed in oral bone: 3 in the maxilla, 1 for sinus augmentation, and 8 in the mandible (Table A2).

- Studies in the maxilla: Studies in the maxilla are mainly used for related sinus augmentation therapies. Medications such as anti-inflammatory drugs and painkillers can be tested for postoperative pain [332]. Newly formed bone height is measurable following sinus floor elevation using a blood clot [333] or for pre-clinical testing of new bone substitute [334], giving an idea of how such materials are accepted in in vivo models. The poor bone quality of the maxillary sinus is also exploited for studying the impact of innovative surface properties in poor quality bone [335].

- Studies in the mandible: Procedures are short, immediate extraction/implantation protocols being the most common. The healing period after implantation is at least 3 weeks [336] and up to 3 months [337]. The incisor area provides a great volume for osseointegration in immediate extraction/implantation protocols with 3-mm diameter and 12-mm length implants [338]. Except for the study by Schiegnitz et al. using 9-month-old New Zealand rabbits (4-5 kg) [336], the age of rabbits is generally not specified accurately; rather, it is reported as "adult age" which corresponds to 2.5 to $6 \mathrm{~kg}$. Only one study found was performed in younger rabbits (4 months old), these having been exposed to fluoride since 2 months of age [337]. Studies in the rabbit mandible have been used to assess osseointegration of implants with different surface properties [339] or positions [336,340], and the systemic effect of exposure to molecules like fluoride [337] or the effect of thyroid hormone production [65]. It should be noted that one proof of concept study for a peri-implantitis model was conducted on the first mandible anterior tooth with silk ligatures in 2015 (reported only in Chinese, except for the abstract [341]). In the mandible, an extra-oral approach by opening a flap from the skin to the mandible angle has been used for vertical bone growth, making it possible to extend the scope of already known materials [342]. The great volume available in this area allows the use of human-sized implants, with a length of $8 \mathrm{~mm}$ and a diameter of $4.1 \mathrm{~mm}$.

Summary: Rabbit models have an extensive history of use and well-developed protocols in studies in orthopedics and more recently periodontal diseases. The weak bone quality around the oral cavity, however, limits the use of long bone in this model for implantology, biocompatibility, or osteoinduction [6].

Nonetheless, rabbit models allow analysis of numerous implants per animal, thereby reducing the total number of animals needed per protocol (Table A1). Their application remains limited due to the small number of genetic models.

\section{Appendix A.5. Research in Rat Models}

Protocol durations depend on the site, with substantial differences between studies. The average age of animals is around 2 to 3 months for the first surgery. For long bone procedures, 2 to 6 weeks is needed before assessing osseointegration. In the case of implant placement at a healed extraction site, 1.5 months of healing is generally allowed after extraction and another month for implant osseointegration (Figure 2). In the maxilla, protocols are shortened, with implantation performed immediately after extraction.

\section{Appendix A.5.1. Long Bone Models}

- Studies in the tibia: The rat tibia is suitable for bone implantation due to the ease of access and relatively good volume. Notably, 32 out of the 68 studies found have been performed with this bone. The medial tibial plate of the bone is commonly used as it is flat and can receive implants [343]. Depending on the prototype used, the number 
of tests and their size differ. At least one implant per tibia can be tested with a nearly human-size implant (2.0 $\mathrm{mm}$ in diameter and 4- to 5-mm in length [83,344-346]). On this kind of model, bi-cortical anchorage can be achieved. For multi-implant protocols, a diameter of $1.5 \mathrm{~mm}$ and length of $2.5 \mathrm{~mm}$ are more appropriate [343,347].

- Research using the rat tibia model has commonly investigated the effects of the implant surface on osseointegration [343,344], but a new trend has emerged, with growing numbers of studies in the areas of the drug delivery and/or physiopathology: effects on osseointegration of different doses of drugs in rats that are healthy [345] or have certain diseases, e.g., diabetes [348-354], or in peri-implant bone defects [346]. Nevertheless, the framework of choice is implantation osseointegration in poor quality bone with drug treatments [355,356]. Research into bisphosphonates [347,355,357-359] or agonists like selective estrogen receptor modulators $[347,360]$ is typically conducted in the rat as it is an excellent model of osteoporosis. Other diseases, such as arthritis [361] or Crohn's disease [362] and the effects of severe dietary magnesium deficiency on systemic bone density, have been investigated [363]. Finally, the rat tibia can also be used for mechanical testing, including in dynamic loading models [364,365], as well as for exploring the effects of pulsed ultrasound [366] or laser therapy [367].

- Studies in the femur: Only a few studies have been conducted in femoral bone mainly due to (i) the short length of the bone and (ii) the amount of muscle and tissue surrounding it. Nonetheless, titanium mesh [368] and implants have been placed for surface testing [369] in diabetic rats [370-372] or in combination with dietary supplements [373] or cell therapy [374].

\section{Appendix A.5.2. Oral Bone Models}

Research in implantology tends to focus on oral bone for the sake of model legitimacy. In small animals, like rats, protocols have to be adapted to be suitable. Various strategies for the maxilla and mandible have been developed in the rat and illustrate some ways protocols can be adapted. Tooth extraction and subsequent dental implant placement is the best proxy procedure in terms of "human-like protocols".

- Studies in the maxilla: Numerous studies have assessed the validity of the maxillary molar site, but with no established guidelines and considerable heterogeneity between protocols. For this procedure, the implants or "mini-screws" measure approximately $1 \mathrm{~mm}$ in width and $2 \mathrm{~mm}$ in length, though some authors prefer longer and wider implants for good primary stability despite the increase in the risk of sinus perforation [375]. In any case, maxillary molars seem to be an adequate place for implant-prototype anchorage immediately after extraction [376] or with a delay $[375,377]$. Another possibility is to use the maxillary diastema, mesial to the molars. A recent study has successfully shown a model of peri-implantitis in this area [378], but the validity of this model has yet to be demonstrated [379]. The maxilla is also used for classic implant surface comparisons [376], mechanical testing [380], and analysis of pathophysiological processes [381-385].

- Studies in the mandible: Beyond the maxilla, two studies have been found that used the mandibular region: one protocol used the posterior part of the mandible in the ramus through an extra-oral approach [386]; and in the other, the implant took the place of the first mandibular molar after extraction and healing for a month [387]. Both protocols led to significant osseointegration, but the latter seems to be more physiologically relevant as it replaces a previous tooth in alveolar bone.

- Contribution of peri-implantitis studies in rat models to implantology: In periodontology, in humans, as in many other animals, chronic inflammation needs to be produced at the sulci of the tooth (with silk ligatures and/or microbial gavage) to produce periodontal destruction [388]. In the same way, peri-implantitis can be induced with a mixed bacterial infection (Streptococcus oralis and Aggregatibacter actinomycetemcomitans) [378]. 
Summary: The rat offers numerous advantages for implantology studies: it is a well-known model for systemic variation (diabetes, hormones), and therefore, for osseointegration in models of poor bone quality (Table A1). On the other hand, opportunities for genetic studies remain limited compared to those with mouse models.

\section{Appendix A.6. Research in Mouse Models}

It seems that 8 weeks is the minimum age of mice for implantation. For protocols in oral bone, 4 to 8 weeks are needed for alveolar healing and 3-4 weeks for implant osseointegration. This is the same length of time as for osseointegration in the tibia (Figure 2).

\section{Appendix A.6.1. Back of the Mouse}

Only one study was found using the back of mice. It sought to analyze the potential bacterial infection originating from the implant itself during surgery. This model was used as it offered a closed environment with no potential interaction, unlike in the case of the mouth [389].

\section{Appendix A.6.2. Long Bone Models}

- Studies in the tibia: with only two studies found from this decade, it seems that the shin has fallen into disuse. One was considered a mouse study but the animal species used was actually Rattus norvegicus, that is, the article had been erroneously classified [390], and the other was conducted to analyze peri-implant bone density in senescence-accelerated mice, but the choice of the shin over femur was not explained in detail [391].

- $\quad$ Studies in the femur: The femur is more commonly used, but nonetheless only a few studies were found. The most common topic is the evaluation of implant osseointegration associated with disease. Diabetes is the most studied disease in association, for example, with drug therapies (1 $\alpha, 25$-Dihydroxyvitamin D3 [392]; transcription factors [HIF-1 $\alpha$ ] [393]). Innovative genetic technologies for lentiviral vector transfection are also useful for testing new treatments [394], or a specific molecular pathway [395]. For this bone, the common prototype is an implant-like model, mostly with a pin-shaped implant $1 \mathrm{~mm}$ in diameter and 2- to 3-mm in length [392,394]. Titanium discs are also used if the aim is to test the biocompatibility of the material [395].

Appendix A.6.3. Oral Bone Models

- Studies in the maxilla: No studies were found on the mandible due to the difficulty of access and mechanical difficulties for manufacturing miniature implants [4]. The maxilla is a relatively recent model, having been developed during the last 10 years [396]. It has become the most common model used in mice (Table A2). Nonetheless, due to the recent description of this model, research is focused on the development of the model itself more than on its implementation. The first model in the dental area, reported in 2014, used "retopins" (0.6-mm diameter cut to a 2-mm length, NTI Kahla $\mathrm{GmbH}$, Germany) positioned in the mesial part of the first maxillary molar. This model demonstrated that osseointegration in oral bone cannot be compared to long bone studies [87,397], but it has recently been shown to be a suitable tool for the assessment of biological events associated with the osseointegration process [398]. This protocol has also been adapted for analysis of (i) immediate post-extraction implant placement [399-401] and (ii) the involvement of different pathways [397,402]. This site can also be used to test new implant compositions, such as a bio-implant [403].

- Contribution of peri-implantitis studies in mouse models to implantology: In order to investigate how to manage infectious conditions, there is also a need to identify a new model of peri-implantitis in the maxilla. Five different studies have proposed different peri-implantitis models: 
o The first one was also the first study to anchor an implant in the oral cavity [396]. The pin-shaped implant was placed in the medial line of the hard palate and periimplantitis was induced with a special diet enriched with sugar and flavorings.

o Pirih et al. developed two new peri-implantitis models with a 1-mm length/0.5-mm diameter implant placed in the second and third maxillary molar area: (1) using silk ligatures placed apically to the implant head [404] and (2) using lipopolysaccharide injections on the implant surface [405].

o Another silk model validated the maxillary molars as a potential site for periimplantitis [406]. This model was later used for the comparison of peri-implantitis and periodontitis progression [407].

o Peri-implantitis was also obtained in a recent study of oral infection with Porphyromonas gingivalis [408]. Since the model has been well established, some applications have emerged, namely, analysis of the impact of different implant surfaces on periimplantitis [409] or inflammation pathways [410].

Summary: Mice seem to be a promising model for genetic research thanks to the ability to perform knock-out studies and the availability of models of human disease. New approaches are emerging, such as peri-implantitis protocols, extending the range of possibilities in this model (Table A1).

On the other hand, mice have obvious limitations typical of small animal models. Implant adaptation in the oral cavity is a limitation both from a surgical and industrial point of view (Figure 4). This disadvantage should be seen as a challenge and may be addressed thanks to technological advances.

\section{References}

1. Vignoletti, F.; Abrahamsson, I. Quality of reporting of experimental research in implant dentistry. Critical aspects in design, outcome assessment and model validation. J. Clin. Periodontol. 2012, 39, 6-27. [CrossRef] [PubMed]

2. Stadlinger, B.; Pourmand, P.; Locher, M.C.; Schulz, M.C. Systematic review of animal models for the study of implant integration, assessing the influence of material, surface and design. J. Clin. Periodontol. 2012, 39, 28-36. [CrossRef]

3. Thoma, D.S.; Martin, I.S.; Mühlemann, S.; Jung, R.E. Systematic review of pre-clinical models assessing implant integration in locally compromised sites and/or systemically compromised animals. J. Clin. Periodontol. 2012, 39, 37-62. [CrossRef] [PubMed]

4. Dard, M. Methods and interpretation of performance studies for dental implants. In Biocompatibility and Performance of Medical Devices; Elsevier: Amsterdam, The Netherlands, 2012; Volume 13, p. 308.

5. Mushcler, G.; Raut, V.; Patterson, T. The design and use of animal models for translational research in bone tissue engineering and regenerative medicine. Tissue Eng. Part B Rev. 2010, 16, 123-145.

6. Wancket, L.M. Animal Models for Evaluation of Bone Implants and Devices: Comparative Bone Structure and Common Model Uses. Vet. Pathol. 2015, 52, 842-850. [CrossRef] [PubMed]

7. Jerome, C.P.; Peterson, P.E. Nonhuman primate models in skeletal research. Bone 2001, 29, 1-6. [CrossRef]

8. Schou, S.; Holmstrup, P.; Kornman, K. Non-human primates used in studies of periodontal disease pathogenesis: A review of the literature. J. Periodontol. 1993, 64, 497-508. [CrossRef]

9. Schwarz, F.; Sculean, A.; Engebretson, S.P.; Becker, J.; Sager, M. Animal models for peri-implant mucositis and peri-implantitis. Periodontol. 2000 2015, 68, 168-181. [CrossRef]

10. Pellegrini, G.; Seol, Y.J.; Gruber, R.; Giannobile, W.V. Pre-clinical Models for Oral and Periodontal Reconstructive Therapies. J. Dent. Res. 2009, 1065-1076. [CrossRef]

11. Kleinert, M.; Clemmensen, C.; Hofmann, S.M.; Moore, M.C.; Renner, S.; Woods, S.C.; Huypens, P.; Beckers, J.; De Angelis, M.H.; Schürmann, A.; et al. Animal models of obesity and diabetes mellitus. Nat. Publ. Gr. 2018, 14, 140-162. [CrossRef]

12. Schroeder, H.E.; Lindhe, J. Conversion of stable established gingivitis in the dog into destructive periodontitis. Arch. Oral Biol. 1975, 20, 775-782. [CrossRef]

13. Ericsson, I.; Lindhe, J.; Rylander, H.; Okamoto, H. Experimental periodontal breakdown in the dog. Eur. J. Oral Sci. 1975, 83, 189-192. [CrossRef]

14. Syed, S.; Svanberg, M.; Svanberg, G. The predominant cultivable dental plaque flora of beagle dogs with periodontitis. J. Clin. Periodontol. 1981, 8, 45-56. [CrossRef] [PubMed]

15. Page, R.; Schroeder, H. Spontaneous Chronic Periodontitis in Adult Dogs. J. Periodontol. 1981, 52, 60-73. [CrossRef]

16. Food and Drug Administration. New Drug Application Database. Available online: https://www.fda.gov/animalveterinary/animal-health-literacy/idea-marketplace-journey-animal-drug-through-approval-process\#approved (accessed on 9 September 2021).

17. Brooks, M. TOP 100 Most Prescribed, Top-Selling Drugs. Medscape. 2015. Available online: https://www.medscape.com/ viewarticle/825053 (accessed on 9 September 2021). 
18. Batas, L.; Stavropoulos, A.; Papadimitriou, S.; Nyengaard, J.R.; Konstantinidis, A. Evaluation of autogenous PRGF+ $\beta$-TCP with or without a collagen membrane on bone formation and implant osseointegration in large size bone defects. A preclinical in vivo study. Clin. Oral Implants Res. 2016, 27, 981-987. [CrossRef]

19. Pearce, A.; Richards, R.; Milz, S.; Schneider, E.; Pearce, S. Animal models for implant biomaterial research in bone: A review. Eur. Cells Mater. 2007, 13,1-10. [CrossRef]

20. Berglundh, T.; Lindhe, J.; Marinell, C.; Ericsson, I.; Liljenberg, B. Soft tissue reaction to de novo plaque formation on implants and teeth. An experimental study in the dog. Clin. Oral Implants Res. 1992, 3, 1-8. [CrossRef]

21. Lindhe, J.; Berglundh, T.; Ericsson, I.; Liljenberg, B.; Marinello, C. Experimental breakdown of peri-implant and periodontal tissues. A study in the beagle dog. Clin. Oral Implants Res. 1992, 3, 9-16. [CrossRef]

22. Zitzmann, N.U.; Berglundh, T.; Ericsson, I.; Lindhe, J. Spontaneous progression of experimentally induced periimplantitis. J. Clin. Periodontol. 2004, 31, 845-849. [CrossRef] [PubMed]

23. Albouy, J.P.; Abrahamsson, I.; Persson, L.G.; Berglundh, T. Spontaneous progression of peri-implantitis at different types of implants. An experimental study in dogs. I: Clinical and radiographic observations. Clin. Oral Implants Res. 2008, 19, 997-1002. [CrossRef] [PubMed]

24. Albouy, J.P.; Abrahamsson, I.; Persson, L.G.; Berglundh, T. Spontaneous progression of ligatured induced peri-implantitis at implants with different surface characteristics. An experimental study in dogs II: Histological observations. Clin. Oral Implants Res. 2009, 20, 366-371. [CrossRef] [PubMed]

25. Aerssens, J.; Boonen, S.; Lowet, G.; Dequeker, J. Interspecies Differences in Bone Composition, Density, and Quality: Potential Implications for in Vivo Bone Research. Endocrinology 1998, 139, 663-670. [CrossRef]

26. Wang, X.; Mabrey, J.; Agrawal, C. An interspecies comparison of bone fracture properties. Biomed. Mater. Eng. 1998, 8, 1-9.

27. Kimmel, D.; Jee, W. A quantitative histologic study of bone turnover in young adult beagles. Anat. Rec. 1982, 203, 31-45. [CrossRef]

28. Polig, E.; Jee, W. Bone structural parameters, dosimetry, and relative radiation risk in the beagle skeleton. Radiat. Res. 1989, 120, 83-101. [CrossRef]

29. Huja, S.S.; Beck, F.M. Bone remodeling in maxilla, mandible, and femur of young dogs. Anat. Rec. 2008, 291, 1-5. [CrossRef]

30. Magee, F.; Longo, J.; Hedley, A. The effect of age on the interface strength between porous coated implants and bone. Trans. Orthopaed. Res. Soc. 1989, 14, 575.

31. Caroprese, M.; Lang, N.P.; Rossi, F.; Ricci, S.; Favero, R.; Botticelli, D. Morphometric evaluation of the early stages of healing at cortical and marrow compartments at titanium implants: An experimental study in the dog. Clin. Oral Implants Res. 2017, 28, 1030-1037. [CrossRef]

32. Koschmieder, R.; Ritzerfield, W.; Homeyer, L. Addition of gentamicine to polymethyl methacrylate for therapy of infectious bone diseases. Experimental in vivo tests. Orthop Ihre Grenzgeb 1975, 113, 147-149.

33. Swindle, M.M.; Makin, A.; Herron, A.J.; Clubb, F.J.; Frazier, K.S. Swine as Models in Biomedical Research and Toxicology Testing. Vet. Pathol. 2011, 49, 344-356. [CrossRef] [PubMed]

34. Buser, D.; Schenk, R.K.; Steinemann, S.; Fiorellini, J.P.; Fox, C.H. Influence of Surface Characteristcs on Bone Integration of Titanium Implants. J. Biomed. Mater. Res. 1991, 25, 889-902. [CrossRef]

35. Xing, K.; Zhu, F.; Zhai, L.; Chen, S.; Tan, Z.; Sun, Y.; Hou, Z.; Wang, C. Identification of genes for controlling swine adipose deposition by integrating transcriptome, whole-genome resequencing, and quantitative trait loci data. Sci. Rep. 2016, 6, 23219. [CrossRef]

36. McAnulty, P.; Dayan, A.; Ganderup, N.; Hastings, K. The Minipig in Biomedical Research; CRC Press: Boca Raton, FL, USA, 2012.

37. Reichert, J.; Saifzadeh, S.; Wullschleger, M. The challenge of establishing preclinical models for segmental bone defect research. Biomaterials 2009, 30, 2149-2163. [CrossRef]

38. Hillier, M.L.; Bell, L.S. Differentiating Human Bone from Animal Bone: A Review of Histological Methods. J. Forensic Sci. 2007, 52, 249-263. [CrossRef]

39. Cummaudo, M.; Cappella, A.; Giacomini, F.; Raffone, C.; Màrquez-Grant, N.; Cattaneo, C. Histomorphometric analysis of osteocyte lacunae in human and pig: Exploring its potential for species discrimination. Int. J. Legal Med. 2019, 133, 711-718. [CrossRef]

40. Inui, A.; Itamoto, K.; Takuma, T.; Tsutsumi, H.; Tanigawa, M.; Hayasaki, M.; Taura, Y.; Mamba, K. Age-related changes of bone mineral density and microarchitecture in miniature pigs. J. Vet. Med. Sci. 2004, 66, 599-609. [CrossRef] [PubMed]

41. Turner, S.; Turner, A.S.; Turner, A.S.; Turner, A.S. Animal models of osteoporosis-necessity and limitations. Eur. Cells Mater. 2001, 13, 66-81. [CrossRef]

42. Olsen, M.L.; Aaboe, M.; Hjørting-Hansen, E.; Hansen, A.K. Problems related to an intraoral approach for experimental surgery on minipigs. Clin. Oral Implants Res. 2004, 15, 333-338. [CrossRef] [PubMed]

43. Hönig, J.; Merten, H. Das Göttinger Miniatureschwein (GMS) als Versuchstier in der humanmedizinischen osteologischen Grundlagenforschung. Z Zahnärztl Implant. 1993, 13, 418-426.

44. Smith, A.C.; Swindle, M.M. Preparation of Swine for the Laboratory. ILAR J. 2006, 47, 358-363. [CrossRef]

45. Rozkot, M.; Václavková, E.; Bělková, J. Minipigs as Laboratory Animals-Review. Res. Pig Breed. 2015, 9, 10-14.

46. Gutierrez, K.; Dicks, N.; Glanzner, W.G.; Agellon, L.B.; Bordignon, V. Efficacy of the porcine species in biomedical research. Front. Genet. 2015, 6, 1-9. [CrossRef] 
47. Chappuis, V.; Maestre, L.; Bürki, A.; Barré, S.; Buser, D.; Zysset, P.; Bosshardt, D. Osseointegration of ultrafine-grained titanium with a hydrophilic nano-patterned surface: An in vivo examination in miniature pigs. Biomater. Sci. 2018, 6, 2448-2459. [CrossRef]

48. Wen, B.; Chen, J.; Dard, M.; Cai, Z. The Performance of Titanium-Zirconium Implants in the Elderly: A Biomechanical Comparative Study in the Minipig. Clin. Implant Dent. Relat. Res. 2016, 18, 1200-1209. [CrossRef] [PubMed]

49. Çolpak, H.A.; Gönen, Z.B.; Özdamar, S.; Alkan, A.; Kütük, N. Vertical ridge augmentation using guided bone regeneration procedure and dental pulp derived mesenchymal stem cells with simultaneous dental implant placement: A histologic study in a sheep model. J. Stomatol. Oral Maxillofac. Surg. 2019, 120, 216-223. [CrossRef] [PubMed]

50. Yurttutan, M.E.; Kestane, R.; Keskin, A.; Dereci, O. Biomechanical evaluation of oversized drilling on implant stability-An experimental study in sheep. J. Pak. Med. Assoc. 2016, 66, 147-150.

51. Jimbo, R.; Tovar, N.; Yoo, D.Y.; Janal, M.N.; Anchieta, R.B.; Coelho, P.G. The effect of different surgical drilling procedures on full laser-etched microgrooves surface-treated implants: An experimental study in sheep. Clin. Oral Implants Res. 2014, 25, $1072-1077$. [CrossRef]

52. Abdel-Haq, J.; Karabuda, C.Z.; Arısan, V.; Mutlu, Z.; Kürkçü, M. Osseointegration and stability of a modified sand-blasted acid-etched implant: An experimental pilot study in sheep. Clin. Oral Implants Res. 2011, 22, 265-274. [CrossRef] [PubMed]

53. Sartoretto, S.C.; Calasans-Maia, J. de A.; da Costa, Y.O.; Louro, R.S.; Granjeiro, J.M.; Calasans-Maia, M.D. Accelerated Healing Period with Hydrophilic Implant Placed in Sheep Tibia. Braz. Dent. J. 2017, 28, 559-565. [CrossRef]

54. Varoni, E.; Canciani, E.; Palazzo, B.; Varasano, V.; Chevallier, P.; Petrizzi, L.; Dellavia, C.; Mantovani, D.; Rimondini, L. Effect of Poly-L-Lysine coating on titanium osseointegration: From characterization to in vivo studies. J. Oral Implantol. 2015, 41, 626-631. [CrossRef] [PubMed]

55. He, Y.; Hasan, I.; Keilig, L.; Fischer, D.; Ziegler, L.; Abboud, M.; Wahl, G.; Bourauel, C. Biomechanical characteristics of immediately loaded and osseointegration dental implants inserted into Sika deer antler. Med. Eng. Phys. 2018, 59, 8-14. [CrossRef]

56. Tabassum, A.; Meijer, G.J.; Walboomers, X.F.; Jansen, J.A. Evaluation of primary and secondary stability of titanium implants using different surgical techniques. Clin. Oral Implants Res. 2014, 25, 487-492. [CrossRef] [PubMed]

57. Tabassum, A.; Meijer, G.J.; Walboomers, X.F.; Jansen, J.A. Biological limits of the undersized surgical technique: A study in goats. Clin. Oral Implants Res. 2011, 22, 129-134. [CrossRef]

58. Schouten, C.; Meijer, G.J.; van den Beucken, J.J.J.P.; Spauwen, P.H.M.; Jansen, J.A. A novel implantation model for evaluation of bone healing response to dental implants: The goat iliac crest. Clin. Oral Implants Res. 2010, 21, 414-423. [CrossRef] [PubMed]

59. Sawin, P.B. Morphogenetic studies of the rabbit; regional specificity of hereditary factors affecting homoeotic variations in the axial skeleton. J. Exp. Zool. 1945, 100, 301-329. [CrossRef] [PubMed]

60. Sawin, P.; Crary, D. Genetics of Skeletal Deformities in the Domestic rabbit (Oryctolagus cuniculus). Clin. Orthop. Relat. Res. 1964, 33, 71-90. [CrossRef] [PubMed]

61. Neyt, J.G.; Buckwalter, J.A.; Carroll, C.N. Use of animal models in musculoskeletal research. Iowa Orthop. 1998, 18, $118-123$.

62. Mori, H.; Manabe, M.; Kurachi, Y.; Nagumo, M. Osseointegration of dental implants in rabbit bone with low mineral density. J. Oral Maxillofac. Surg. 1997, 55, 351-361. [CrossRef]

63. Burkholder, T.H.; Linton, G.; Hoyt, R.F.; Young, R. The Rabbit as an Experimental Model, 1st ed.; Elsevier Inc.: Amsterdam, The Netherlands, 2012; ISBN 9780123809209.

64. Association, A.R.B. ARBA Regnition Breed 2011. Available online: https://www.arbadistricts.net/breeds.htm (accessed on 9 September 2021).

65. Weber, J.B.B.; Mayer, L.; Cenci, R.A.; Baraldi, C.E.; Ponzoni, D.; Gerhardt de Oliveira, M. Effect of Three Different Protocols of Low-Level Laser Therapy on Thyroid Hormone Production After Dental Implant Placement in an Experimental Rabbit Model. Photomed. Laser Surg. 2014, 32, 612-617. [CrossRef]

66. Altug, H.A.; Tatli, U.; Coskun, A.T.; Erdogan, Ö.; Özkan, A.; Sencimen, M.; Kürkçü, M. Effects of hyperbaric oxygen treatment on implant osseointegration in experimental diabetes mellitus. J. Appl. Oral Sci. 2018, 26, e20180083. [CrossRef]

67. Oki, Y.; Doi, K.; Makihara, Y.; Kobatake, R.; Kubo, T.; Tsuga, K. Effects of continual intermittent administration of parathyroid hormone on implant stability in the presence of osteoporosis: An in vivo study using resonance frequency analysis in a rabbit model. J. Appl. Oral Sci. 2017, 25, 498-505. [CrossRef] [PubMed]

68. Gilsanz, V.; Roe, T.; Gibbens, D. Effect of sex steroids on peak bone density of growing rabbits. J. Physiol. 1988, 255 , E416-E421. [CrossRef]

69. Brewer, N.R. Biology of the Rabbit. J. Am. Assoc. Lab. Anim. Sci. 2006, 45, 25-26.

70. Martiniakova, M.; Grosskopf, B.; Omelka, R. Histological study of compact bone tissue in some mammals: A method for species determination. Int. J. Osteoarch. 2007, 17, 82-90. [CrossRef]

71. Martiniakova, M.; Grosskopf, B.; Omelka, R. Differences among species in compact bone tissue microstructure of mammalian skeleton: Use of a discriminant function analysis for species identification. J. Forensic Sci. 2006, 51, 1235-1239. [CrossRef] [PubMed]

72. Turner, R.T.; Maran, A.; Lotinun, S.; Hefferan, T.; Evans, M.G.L.; Zhang, M.M. Animal Models for Osteoporosis. Endocr. Metab. Disord. 2001, 2, 117-127. [CrossRef]

73. Dennison, E.; Cole, Z.; Cooper, C. Diagnosis and epidemiology of osteoporosis. Curr. Opin. Rheumatol. 2005, 17, 456-461. [CrossRef] 
74. Jee, W.S.S.; Yao, W. Overview: Animal models of osteopenia and osteoporosis. J. Musculoskel. Neuron. Interact. $2001,1,193-207$.

75. KIM, B.-T.; Tornvig, L.; Thomsen, J.S.; Seeman, E.G.O. The Structural and Hormonal Basis of Sex Differences in Peak Appendicular Bone Strength in Rats. J. Bone Miner. Res. 2003, 18, 150-155. [CrossRef]

76. Koebele, S.V.; Bimonte-Nelson, H.A. Modeling menopause: The utility of rodents in translational behavioral endocrinology research. Maturitas 2016, 87, 5-17. [CrossRef]

77. Luiz, F.; Carlos, M.S.; Alves, A.; Peruzzo, D.C.; Ângelo, V.; Montalli, M.; Duarte, P.M.; Napimoga, M.H. Preliminary Findings on the Role of Sclerostin in the Osseointegration Process Around Titanium Implants. JOMI 2016, 31, 1298-1302. [CrossRef] [PubMed]

78. Aleman, C.; Mas, R.; Rodeiro, I.; Noa, M.; Hernandez, C.; Gamez, R. Reference database of the main physiological parameters in Sp rague-Dawley rats from 6 to 32 months. Lab. Anim. 1998, 32. [CrossRef]

79. Cho, J.; Cho, D.; Kim, K. Effect of dietary calcium on spinal bone fusion in an ovariectomized rat model. J. Korean Neurosurg. Soc. 2012, 52, 281-287. [CrossRef]

80. Staubli, N.; Schmidt, J.C.; Rinne, C.A.; Signer-Buset, S.L.; Rodriguez, F.R.; Walter, C. Animal experiments in periodontal and peri-implant research: Are there any changes? Dent. J. 2019, 7, 1-9. [CrossRef]

81. Beamer, W.; Donahue, L.; Rosen, C.; Baylink, D. Genetic variability in adult bone density among imbred strains of mice. Bone 1996, 18, 397-403. [CrossRef]

82. Johnson, M. Laboratory Mice and rats. Mater. Methods 2020, 2, 13070. [CrossRef]

83. Simon, M.M.; Greenaway, S.; White, J.K.; Fuchs, H.; Gailus-Durner, V.; Wells, S.; Sorg, T.; Wong, K.; Bedu, E.; Cartwright, E.J.; et al. A comparative phenotypic and genomic analysis of C57BL/6J and C57BL/6N mouse strains. Genome Biol. 2013, 14, R82. [CrossRef] [PubMed]

84. Garcia-Perez, J.L.; Munos-Lopez, M. and DNA Transposons: Nature and Applications in Genomics. Curr. Genomics 2010, 11, 115-128.

85. Mizuno, N.; Mizutani, E.; Sato, H.; Kasai, M.; Ogawa, A.; Suchy, F.; Yamaguchi, T.; Nakauchi, H. Intra-embryo Gene Cassette Knockin by CRISPR/Cas9-Mediated Genome Editing with Adeno-Associated Viral Vector. iScience 2018, 9, 286-297. [CrossRef]

86. Chen, J.S.; Dagdas, Y.S.; Kleinstiver, B.P.; Welch, M.M.; Sousa, A.A.; Harrington, L.B.; Sternberg, S.H.; Joung, J.K.; Yildiz, A.; Doudna, J.A. Enhanced proofreading governs CRISPR-Cas9 targeting accuracy. Nature 2017, 550, 407-410. [CrossRef] [PubMed]

87. Mouraret, S.; Hunter, D.J.; Bardet, C.; Brunski, J.B.; Bouchard, P.; Helms, J.A. A pre-clinical murine model of oral implant osseointegration. Bone 2014, 58, 177-184. [CrossRef]

88. Bagi, C.M.; Berryman, E.; Moalli, M.R. Comparative Bone Anatomy of Commonly Used Laboratory Animals: Implications for Drug Discovery. Comp. Med. 2011, 61, 76-85.

89. Ting, M.; Jefferies, S.R.; Xia, W.; Engqvist, H.; Suzuki, J.B. Classification and effects of implant surface modification on the bone: Human cell-based in vitro studies. J. Oral Implantol. 2017, 43, 58-83. [CrossRef] [PubMed]

90. Ting, M.; Whitaker, E.J.; Albandar, J.M. Systematic review of the in vitro effects of statins on oral and perioral microorganisms. Eur. J. Oral Sci. 2016, 124, 4-10. [CrossRef]

91. Webster, T.J.; Ejiofor, J.U. Increased osteoblast adhesion on nanophase metals: Ti, Ti6Al4V, and CoCrMo. Biomaterials 2004, 25, 4731-4739. [CrossRef] [PubMed]

92. Li, Q.; Wang, Z. Involvement of fak/p38 signaling pathways in mediating the enhanced osteogenesis induced by nano-graphene oxide modification on titanium implant surface. Int. J. Nanomed. 2020, 15, 4659-4676. [CrossRef] [PubMed]

93. Kokubo, T.; Yamaguchi, S. Bioactive Titanate Layers Formed on Titanium and Its Alloys by Simple Chemical and Heat Treatments. Open Biomed. Eng. J. 2015, 9, 29-41. [CrossRef]

94. Pattanayak, D.K.; Yamaguchi, S.; Matsushita, T.; Nakamura, T.; Kokubo, T. Apatite-forming ability of titanium in terms of pH of the exposed solution. J. R. Soc. Interface 2012, 9, 2145-2155. [CrossRef]

95. Smeets, R.; Stadlinger, B.; Schwarz, F.; Beck-Broichsitter, B.; Jung, O.; Precht, C.; Kloss, F.; Gröbe, A.; Heiland, M.; Ebker, T. Impact of Dental Implant Surface Modifications on Osseointegration. Biomed Res. Int. 2016, 2016. [CrossRef]

96. Stigter, M.; Bezemer, J.; de Groot, K.; Layrolle, P. Incorporation of different antibiotics into carbonated hydroxyapatite coatings on titanium implants, release and antibiotic efficacy. J. Control. Release 2004, 99, 127-137. [CrossRef]

97. Boyne, P.; Jones, S.D. Demonstration of the osseoinductive effect of bone morphogenetic protein within endosseous dental implants. Implant Dent. 2004, 13, 180-184. [CrossRef] [PubMed]

98. Al-Hashedi, A.A.; Laurenti, M.; Benhamou, V.; Tamimi, F. Decontamination of titanium implants using physical methods. Clin. Oral Implants Res. 2017, 28, 1013-1021. [CrossRef]

99. John, G.; Becker, J.; Schwarz, F. Rotating titanium brush for plaque removal from rough titanium surfaces-An in vitro study. Clin. Oral Implants Res. 2014, 25, 838-842. [CrossRef] [PubMed]

100. Sahrmann, P.; Ronay, V.; Hofer, D.; Attin, T.; Jung, R.E.; Schmidlin, P.R. In vitro cleaning potential of three different implant debridement methods. Clin. Oral Implants Res. 2015, 26, 314-319. [CrossRef] [PubMed]

101. Barbour, M.E.; O'Sullivan, D.J.; Jenkinson, H.F.; Jagger, D.C. The effects of polishing methods on surface morphology, roughness and bacterial colonisation of titanium abutments. J. Mater. Sci. Mater. Med. 2007, 18, 1439-1447. [CrossRef] [PubMed]

102. Suárez-López del Amo, F.; Rudek, I.; Wagner, V.; Martins, M.; O’Valle, F.; Galindo-Moreno, P.; Giannobile, W.; Wang, H.-L.; Castilho, R. Titanium Activates the DNA Damage Response Pathway in Oral Epithelial Cells: A Pilot Study. Int. J. Oral Maxillofac. Implants 2017, 32, 1413-1420. [CrossRef] [PubMed] 
103. Sivaraman, K.; Chopra, A.; Narayan, A.I.; Balakrishnan, D. Is zirconia a viable alternative to titanium for oral implant? A critical review. J. Prosthodont. Res. 2018, 62, 121-133. [CrossRef]

104. Simion, M.; Baldoni, M.; Rossi, P. A study on the attachment of human gingival cell structures to oral implant materials. Int. J. Prosthodont. 1991, 4, 543-547. [PubMed]

105. Mombelli, A. In vitro models of biological responses to implant microbiological models. Adv. Dent. Res. 1999, 13, 67-72. [CrossRef]

106. Irshad, M.; Scheres, N.; Crielaard, W.; Loos, B.G.; Wismeijer, D.; Laine, M.L. Influence of titanium on in vitro fibroblastPorphyromonas gingivalis interaction in peri-implantitis. J. Clin. Periodontol. 2013, 40, 841-849. [CrossRef]

107. Mombelli, A.; Hashim, D.; Cionca, N. What is the impact of titanium particles and biocorrosion on implant survival and complications? A critical review. Clin. Oral Implants Res. 2018, 29, 37-53. [CrossRef] [PubMed]

108. Yan Lin, H.; Liu, Y.; Wismeijer, D.; Crielaard, W.; Mei Deng, D. Effects of Oral Implant Surface Roughness on Bacterial Biofilm Formation and Treatment Efficacy. Int. J. Oral Maxillofac. Implants 2013, 28, 1226-1231. [CrossRef] [PubMed]

109. Streckbein, P.; Streckbein, R.G.; Wilbrand, J.F.; Malik, C.Y.; Schaaf, H.; Howaldt, H.P.; Flach, M. Non-linear 3D evaluation of different oral implant-abutment connections. J. Dent. Res. 2012, 91, 1184-1189. [CrossRef]

110. Duyck, J.; Van Oosterwyck, H.; Vander Sloten, J.; De Cooman, M.; Puers, R.; Naert, I. Pre-load on oral implants after screw tightening fixed full prostheses: An in vivo study. J. Oral Rehabil. 2001, 28, 226-233. [CrossRef]

111. Marchetti, E.; Ratta, S.; Mummolo, S.; Tecco, S.; Pecci, R.; Bedini, R.; Marzo, G. Mechanical Reliability Evaluation of an Oral Implant-Abutment System According to UNI en ISO 14801 Fatigue Test Protocol. Implant Dent. 2016, 25, 613-618. [CrossRef]

112. Blum, K.; Wiest, W.; Fella, C.; Balles, A.; Dittmann, J.; Rack, A.; Maier, D.; Thomann, R.; Spies, B.C.; Kohal, R.J.; et al. Fatigue induced changes in conical implant-abutment connections. Dent. Mater. 2015, 31, 1415-1426. [CrossRef]

113. Kohal, R.J.; Klaus, G.; Strub, J.R. Zirconia-implant-supported all-ceramic crowns withstand long-term load: A pilot investigation. Clin. Oral Implants Res. 2006, 17, 565-571. [CrossRef]

114. Wang, T.; Wang, L.; Lu, Q.; Fan, Z. Changes in the esthetic, physical, and biological properties of a titanium alloy abutment treated by anodic oxidation. J. Prosthet. Dent. 2019, 121, 156-165. [CrossRef]

115. Kramer, F.-J.; Baethge, C.; Swennen, G.; Rosahl, S. Navigated vs. conventional implant insertion for maxillary single tooth replacement. Clin. Oral Implants Res. 2004, 16, 60-68. [CrossRef] [PubMed]

116. Romanos, G.E.; Gutknecht, N.; Dieter, S.; Schwarz, F.; Crespi, R.; Sculean, A. Laser wavelengths and oral implantology. Lasers Med. Sci. 2009, 24, 961-970. [CrossRef]

117. Mangano, F.G.; Veronesi, G.; Hauschild, U.; Mijiritsk, E.; Mangano, C. Trueness and precision of four intraoral scanners in oral implantology: A comparative in vitro study. PLoS ONE 2016, 11, 1-18. [CrossRef] [PubMed]

118. European Parliament. Directive 2010/63/EU of the European Parliament and of the Council of 22 September 2010 on the protection of animals used for scientific purposes (text with EEA relevance). Off. J. Eur. Union 2010, 28, 82-128.

119. Weiss, R.A. Retroviral zoonoses. Nat. Med. 1998, 4, 391-392. [CrossRef]

120. Suomi, S.J. Risk, resilience, and gene-environment interplay in primates. J. Can. Acad. Child Adolesc. Psychiatry 2011, 20, $289-297$.

121. Scala, A.; Botticelli, D.; Rangel, I.G.; De Oliveira, J.A.; Okamoto, R.; Lang, N.P. Early healing after elevation of the maxillary sinus floor applying a lateral access: A histological study in monkeys. Clin. Oral Implants Res. 2010, 21, 1320-1326. [CrossRef]

122. Scala, A.; Botticelli, D.; Faeda, R.S.; Garcia Rangel, I.; Américo de Oliveira, J.; Lang, N.P. Lack of influence of the Schneiderian membrane in forming new bone apical to implants simultaneously installed with sinus floor elevation: An experimental study in monkeys. Clin. Oral Implants Res. 2012, 23, 175-181. [CrossRef]

123. Jungner, M.; Cricchio, G.; Salata, L.A.; Sennerby, L.; Lundqvist, C.; Hultcrantz, M.; Lundgren, S. On the Early Mechanisms of Bone Formation after Maxillary Sinus Membrane Elevation: An Experimental Histological and Immunohistochemical Study. Clin. Implant Dent. Relat. Res. 2015, 17, 1092-1102. [CrossRef] [PubMed]

124. Stokholm, R.; Spin-Neto, R.; Nyengaard, J.R.; Isidor, F. Comparison of radiographic and histological assessment of peri-implant bone around oral implants. Clin. Oral Implants Res. 2016, 27, 782-786. [CrossRef]

125. Siar, C.H.; Toh, C.G.; Ali, T.B.T.; Seiz, D.; Ong, S.T. Dimensional profile of oral mucosa around combined tooth-implant-supported bridgework in macaque mandible. Clin. Oral Implants Res. 2012, 23, 438-446. [CrossRef]

126. Stokholm, R.; Isidor, F.; Nyengaard, J.R. Histologic and histomorphometric evaluation of peri-implant bone of immediate or delayed occlusal-loaded non-splinted implants in the posterior mandible-An experimental study in monkeys. Clin. Oral Implants Res. 2014, 25, 1311-1318. [CrossRef]

127. Singh, I.; Tonna, E.; Gandel, C. A comparative histological study of mammalian bone. J. Morphol. 1974, 144, 421-437. [CrossRef]

128. Coelho, P.G.; Bonfante, E.A.; Pessoa, R.S.; Marin, C.; Granato, R.; Giro, G.; Witek, L.; Suzuki, M. Characterization of Five Different Implant Surfaces and Their Effect on Osseointegration: A Study in Dogs. J. Periodontol. 2011, 82, 742-750. [CrossRef] [PubMed]

129. Lopez, M. de A.; Olate, S.; Lanata-Flores, A.; Pozzer, L.; Cavalieri-Pereira, L.; Cantín, M.; Vásquez, B.; de Albergaria-Barbosa, J. New bone formation in a bone defect associated to dental implant using absorbable or non-absorbable membrane in a dog model. Int. J. Clin. Exp. Pathol. 2013, 6, 2292-2299.

130. Tonetto, A.; Lago, P.W.; Borba, M.; Rosa, V. Effects of chrondro-osseous regenerative compound associated with local treatments in the regeneration of bone defects around implants: An in vivo study. Clin. Oral Investig. 2016, 20, 267-274. [CrossRef] [PubMed]

131. Cardoso, Á.L.; de Paula Lima, C.A.; Montebello Filho, A.; Pereira, A.A. Radiographic analysis of dental implant extensions using bone grafts on dogs. Clin. Implant Dent. Relat. Res. 2018, 20, 222-228. [CrossRef] [PubMed] 
132. Baires-Campos, F.E.; Jimbo, R.; Bonfante, E.A.; Fonseca-Oliveira, M.T.; Moura, C.; Zanetta-Barbosa, D.; Coelho, P.G. Drilling dimension effects in early stages of osseointegration and implant stability in a canine model. Med. Oral Patol. Oral Cir. Bucal 2015, 20, e471-e479. [CrossRef] [PubMed]

133. Campos, F.E.B.; Jimbo, R.; Bonfante, E.A.; Barbosa, D.Z.; Oliveira, M.T.F.; Janal, M.N.; Coelho, P.G. Are insertion torque and early osseointegration proportional? A histologic evaluation. Clin. Oral Implants Res. 2015, 26, 1256-1260. [CrossRef]

134. Coelho, P.G.; Marin, C.; Teixeira, H.S.; Campos, F.E.; Gomes, J.B.; Guastaldi, F.; Anchieta, R.B.; Silveira, L.; Bonfante, E.A. Biomechanical evaluation of undersized drilling on implant biomechanical stability at early implantation times. J. Oral Maxillofac. Surg. 2013, 71, e69-e75. [CrossRef]

135. Gil, L.; Sarendranath, A.; Neiva, R.; Marão, H.; Tovar, N.; Bonfante, E.; Janal, M.; Castellano, A.; Coelho, P. Bone Healing Around Dental Implants: Simplified vs Conventional Drilling Protocols at Speed of $400 \mathrm{rpm}$. Int. J. Oral Maxillofac. Implants 2017, 32, 329-336. [CrossRef]

136. Jimbo, R.; Janal, M.N.; Marin, C.; Giro, G.; Tovar, N.; Coelho, P.G. The effect of implant diameter on osseointegration utilizing simplified drilling protocols. Clin. Oral Implants Res. 2014, 25, 1295-1300. [CrossRef]

137. Patel, A.; Gil, L.; Castellano, A.; Freitas, G.; Navarro, D.; Peredo, A.; Tovar, N.; Coelho, P. Effect of Simplified One-Step Drilling Protocol on Osseointegration. Int. J. Periodontics Restorative Dent. 2016, e82-e87. [CrossRef]

138. Coelho, P.G.; Granato, R.; Marin, C.; Jimbo, R.; Lin, S.; Witek, L.; Suzuki, M.; Bonfante, E.A. Effect of Si addition on Ca- and P-impregnated implant surfaces with nanometer-scale roughness: An experimental study in dogs. Clin. Oral Implants Res. 2012, 23, 373-378. [CrossRef]

139. Coelho, P.G.; Marin, C.; Granato, R.; Giro, G.; Suzuki, M.; Bonfante, E.A. Biomechanical and histologic evaluation of non-washed resorbable blasting media and alumina-blasted/acid-etched surfaces. Clin. Oral Implants Res. 2012, 23, 132-135. [CrossRef] [PubMed]

140. Teixeira, H.S.; Marin, C.; Witek, L.; Freitas, A.; Silva, N.R.F.; Lilin, T.; Tovar, N.; Janal, M.N.; Coelho, P.G. Assessment of a chair-side argon-based non-thermal plasma treatment on the surface characteristics and integration of dental implants with textured surfaces. J. Mech. Behav. Biomed. Mater. 2012, 9, 45-49. [CrossRef] [PubMed]

141. de Jesus, R.N.R.; Carrilho, E.; Antunes, P.V.; Ramalho, A.; Moura, C.C.G.; Stavropoulos, A.; Zanetta-Barbosa, D. Interfacial biomechanical properties of a dual acid-etched versus a chemically modified hydrophilic dual acid-etched implant surface: An experimental study in Beagles. Int. J. Implant Dent. 2018, 4, 1-10. [CrossRef]

142. Marin, C.; Granato, R.; Bonfante, E.A.; Suzuki, M.; Janal, M.N.; Coelho, P.G. Evaluation of a nanometer roughness scale resorbable media-processed surface: A study in dogs. Clin. Oral Implants Res. 2012, 23, 119-124. [CrossRef] [PubMed]

143. Ikumi, N.; Suzawa, T.; Yoshimura, K.; Kamijo, R. Bone Response to Static Compressive Stress at Bone-Implant Interface: A Pilot Study of Critical Static Compressive Stress. Int. J. Oral Maxillofac. Implants 2015, 30, 827-833. [CrossRef]

144. Zhu, L.; Yang, J.; Gong, J.; Zhang, C.; Wang, H. Optimized beagle model for maxillary sinus floor augmentation via a mini-lateral window with simultaneous implant placement. J. Int. Med. Res. 2018, 46, 4684-4692. [CrossRef]

145. Elhamruni, L.M.M.; Marzook, H.A.M.; Ahmed, W.M.S.; Abdul-Rahman, M. Experimental study on penetration of dental implants into the maxillary sinus at different depths. Oral Maxillofac. Surg. 2016, 20, 281-287. [CrossRef] [PubMed]

146. Si, M.S.; Mo, J.J.; Zhuang, L.F.; Gu, Y.X.; Qiao, S.C.; Lai, H.C. Osteotome sinus floor elevation with and without grafting: An animal study in Labrador dogs. Clin. Oral Implants Res. 2015, 26, 197-203. [CrossRef]

147. Jeong, S.M.; Lee, C.U.; Son, J.S.; Oh, J.H.; Fang, Y.; Choi, B.H. Simultaneous sinus lift and implantation using platelet-rich fibrin as sole grafting material. J. Cranio-Maxillofacial Surg. 2014, 42, 990-994. [CrossRef] [PubMed]

148. Thoma, D.S.; Jung, U.W.; Park, J.Y.; Bienz, S.P.; Hüsler, J.; Jung, R.E. Bone augmentation at peri-implant dehiscence defects comparing a synthetic polyethylene glycol hydrogel matrix vs. standard guided bone regeneration techniques. Clin. Oral Implants Res. 2017, 28, e76-e83. [CrossRef] [PubMed]

149. Seo, G.Y.; Thoma, D.S.; Jung, U.W.; Lee, J.S. Increasing the tissue thickness at implant sites using guided bone regeneration and an additional collagen matrix: Histologic observations in beagle dogs. J. Biomed. Mater. Res. Part B Appl. Biomater. 2019, 107, 741-749. [CrossRef]

150. Benic, G.I.; Thoma, D.S.; Sanz-Martin, I.; Munoz, F.; Hämmerle, C.H.F.; Cantalapiedra, A.; Fischer, J.; Jung, R.E. Guided bone regeneration at zirconia and titanium dental implants: A pilot histological investigation. Clin. Oral Implants Res. 2017, 28, 1592-1599. [CrossRef]

151. Beolchini, M.; Lang, N.P.; Viganò, P.; Bengazi, F.; Triana, B.G.; Botticelli, D.D. The edentulous ridge expansion (ERE) technique an experimental study in the dog. Clin. Oral Implants Res. 2014, 25, 1207-1211. [CrossRef] [PubMed]

152. Beolchini, M.; Lang, N.P.; Ricci, E.; Bengazi, F.; Triana, B.G.; Botticelli, D. Influence on alveolar resorption of the buccal bony plate width in the edentulous ridge expansion (E.R.E.)—An experimental study in the dog. Clin. Oral Implants Res. 2015, 26, 109-114. [CrossRef]

153. Rossi, F.; Lang, N.P.; De Santis, E.; Morelli, F.; Favero, G.; Botticelli, D. Bone-healing pattern at the surface of titanium implants: An experimental study in the dog. Clin. Oral Implants Res. 2014, 25, 124-131. [CrossRef] [PubMed]

154. Canullo, L.; Tallarico, M.; Botticelli, D.; Alccayhuaman, K.A.A.; Martins Neto, E.C.; Xavier, S.P. Hard and soft tissue changes around implants activated using plasma of argon: A histomorphometric study in dog. Clin. Oral Implants Res. 2018, 29, 389-395. [CrossRef] 
155. Teng, F.; Chen, H.; Xu, Y.; Liu, Y.; Ou, G. Polydopamine deposition with anodic oxidation for better connective tissue attachment to transmucosal implants. J. Periodontal Res. 2018, 53, 222-231. [CrossRef]

156. Gehrke, S.A.; Bragança, L.K.; Velasco-Ortega, E.; Calvo-Guirado, J.L. Evaluation of dimensional behavior of peri-implant tissues in implants immediately exposed or submerged in fresh extraction and healed sites: A histological study in dogs. Int. J. Implant Dent. 2018, 4. [CrossRef]

157. Sanz-Martin, I.; Vignoletti, F.; Nuñez, J.; Permuy, M.; Muñoz, F.; Sanz-Esporrín, J.; Fierravanti, L.; Shapira, L.; Sanz, M. Hard and soft tissue integration of immediate and delayed implants with a modified coronal macro-design. Histologic, Micro-CT and volumetric soft tissues changes from a pre-clinical in-vivo study. J. Clin. Periodontol. 2017, 44, 842-853. [CrossRef]

158. Manresa, C.; Bosch, M.; Manzanares, M.C.; Carvalho, P.; Echeverría, J.J. A new standardized-automatic method for bone-toimplant contact histomorphometric analysis based on backscattered scanning electron microscopy images. Clin. Oral Implants Res. 2014, 25, 702-706. [CrossRef] [PubMed]

159. Becker, K.; Drescher, D.; Hönscheid, R.; Golubovic, V.; Mihatovic, I.; Schwarz, F. Biomechanical, micro-computed tomographic and immunohistochemical analysis of early osseous integration at titanium implants placed following lateral ridge augmentation using extracted tooth roots. Clin. Oral Implants Res. 2017, 28, 334-340. [CrossRef] [PubMed]

160. Sanz-Martín, I.; Permuy, M.; Vignoletti, F.; Nuñez, J.; Muñoz, F.; Sanz, M. A novel methodological approach using superimposed Micro-CT and STL images to analyze hard and soft tissue volume in immediate and delayed implants with different cervical designs. Clin. Oral Implants Res. 2018, 29, 986-995. [CrossRef]

161. Fetner, M.; Fetner, A.; Koutouzis, T.; Clozza, E.; Tovar, N.; Sarendranath, A.; Coelho, P.; Neiva, K.; Janal, M.; Neiva, R. The Effects of Subcrestal Implant Placement on Crestal Bone Levels and Bone-to-Abutment Contact: A Microcomputed Tomographic and Histologic Study in Dogs. Int. J. Oral Maxillofac. Implants 2015, 30, 1068-1075. [CrossRef] [PubMed]

162. Cesaretti, G.; Lang, N.P.; Salata, L.A.; Schweikert, M.T.; Gutierrez Hernandez, M.E.; Botticelli, D. Sub-crestal positioning of implants results in higher bony crest resorption: An experimental study in dogs. Clin. Oral Implants Res. 2015, 26, 1355-1360. [CrossRef]

163. Huang, B.; Meng, H.; Zhu, W.; Witek, L.; Tovar, N.; Coelho, P.G. Influence of placement depth on bone remodeling around tapered internal connection implants: A histologic study in dogs. Clin. Oral Implants Res. 2015, 26, 942-949. [CrossRef]

164. Okada, S.; Koretake, K.; Miyamoto, Y.; Oue, H.; Akagawa, Y. Increased Crown-To-Implant Ratio May Not Be a Risk Factor for Dental Implant Failure under Appropriate Plaque Control. PLoS ONE 2013, 8, 1-7. [CrossRef] [PubMed]

165. De Carvalho Cardoso, L.; Poi, W.R.; Botticelli, D.; Junior, I.R.G.; Pantani, F.; Pereira, C.C.S. Osseointegration at implants placed into delayed reimplanted roots: An experimental study in dogs. Clin. Oral Implants Res. 2014, 25, 610-615. [CrossRef]

166. Calvo-Guirado, J.L.; Delgado-Peña, J.; Maté-Sánchez, J.E.; Mareque Bueno, J.; Delgado-Ruiz, R.A.; Romanos, G.E. Novel hybrid drilling protocol: Evaluation for the implant healing-Thermal changes, crestal bone loss, and bone-to-implant contact. Clin. Oral Implants Res. 2015, 26, 753-760. [CrossRef]

167. Rea, M.; Lang, N.P.; Ricci, S.; Mintrone, F.; González González, G.; Botticelli, D. Healing of implants installed in over- or under-prepared sites-An experimental study in dogs. Clin. Oral Implants Res. 2015, 26, 442-446. [CrossRef]

168. Seo, D.U.; Kim, S.G.; Oh, J.S.; Lim, S.C. Comparative study on early osseointegration of implants according to various drilling speeds in the mandible of dogs. Implant Dent. 2017, 26, 841-847. [CrossRef] [PubMed]

169. Guirado, J.L.C.; Troiano, M.; López-López, P.J.; Ramírez-Fernandez, M.P.; de Val, J.E.M.S.; Marin, J.M.G.; Gehrke, S.A. Different configuration of socket shield technique in peri-implant bone preservation: An experimental study in dog mandible. Ann. Anat. 2016, 208, 109-115. [CrossRef]

170. Tan, Z.; Kang, J.; Liu, W.; Wang, H. The effect of the heights and thicknesses of the remaining root segments on buccal bone resorption in the socket-shield technique: An experimental study in dogs. Clin. Implant Dent. Relat. Res. 2018, 20, 352-359. [CrossRef] [PubMed]

171. Haga-Tsujimura, M.; Nakahara, K.; Kobayashi, E.; Igarashi, K.; Schaller, B.; Saulacic, N. Single-staged implant placement using bone ring technique with and without membrane placement: An experimental study in the Beagle dog. Clin. Oral Implants Res. 2018, 29, 263-276. [CrossRef]

172. Nakahara, K.; Haga-Tsujimura, M.; Igarashi, K.; Kobayashi, E.; Schaller, B.; Lang, N.P.; Saulacic, N. Single-staged implant placement using the bone ring technique with and without membrane placement: Micro-CT analysis in a preclinical in vivo study. Clin. Oral Implants Res. 2020, 31, 29-36. [CrossRef]

173. Passoni, B.B.; Marques de Castro, D.S.; de Araújo, M.A.R.; de Araújo, C. d. R.P.; Piatelli, A.; Benfatti, C.A.M. Influence of immediate/delayed implant placement and implant platform on the peri-implant bone formation. Clin. Oral Implants Res. 2016, 27, 1376-1383. [CrossRef] [PubMed]

174. Negri, B.; López Marí, M.; Maté Sánchez de Val, J.E.; Iezzi, G.; Bravo González, L.A.; Calvo Guirado, J.L. Biological width formation to immediate implants placed at different level in relation to the crestal bone: An experimental study in dogs. Clin. Oral Implants Res. 2015, 26, 788-798. [CrossRef] [PubMed]

175. Vignoletti, F.; Sanz-Esporrin, J.; Sanz-Martin, I.; Nuñez, J.; Luengo, F.; Sanz, M. Ridge alterations after implant placement in fresh extraction sockets or in healed crests: An experimental in vivo investigation. Clin. Oral Implants Res. 2019, 30, 353-363. [CrossRef]

176. Favero, G.; Lang, N.P.; Romanelli, P.; Pantani, F.; Caneva, M.; Botticelli, D. A digital evaluation of alveolar ridge preservation at implants placed immediately into extraction sockets: An experimental study in the dog. Clin. Oral Implants Res. 2015, 26, 102-108. [CrossRef] 
177. Discepoli, N.; Vignoletti, F.; Laino, L.; de Sanctis, M.; Muñoz, F.; Sanz, M. Fresh extraction socket: Spontaneous healing vs. immediate implant placement. Clin. Oral Implants Res. 2015, 26, 1250-1255. [CrossRef] [PubMed]

178. Bressan, E.; Sivolella, S.; Stellini, E.; Almagro Urrutia, Z.; Lang, N.P.; Botticelli, D. Healing of buccal dehiscence defects at implants installed immediately into extraction sockets-An experimental study in dogs. Clin. Oral Implants Res. 2013, 24, 270-277. [CrossRef] [PubMed]

179. Pereira, F.P.; Hochuli-Vieira, E.; Maté Sánchez de Val, J.E.; De Santis, E.; Salata, L.A.; Botticelli, D. Bone Ceramic ${ }^{\circledR}$ at Implants Installed Immediately into Extraction Sockets in the Molar Region: An Experimental Study in Dogs. Clin. Implant Dent. Relat. Res. 2016, 18, 360-368. [CrossRef]

180. Mainetti, T.; Lang, N.P.; Bengazi, F.; Sbricoli, L.; Soto Cantero, L.; Botticelli, D. Immediate loading of implants installed in a healed alveolar bony ridge or immediately after tooth extraction: An experimental study in dogs. Clin. Oral Implants Res. 2015, 26, 435-441. [CrossRef]

181. Rea, M.; Botticelli, D.; Ricci, S.; Soldini, C.; González, G.G.; Lang, N.P. Influence of immediate loading on healing of implants installed with different insertion torques-An experimental study in dogs. Clin. Oral Implants Res. 2015, 26, 90-95. [CrossRef] [PubMed]

182. Lima, L.A.; Bosshardt, D.D.; Chambrone, L.; Araújo, M.G.; Lang, N.P. Excessive occlusal load on chemically modified and moderately rough titanium implants restored with cantilever reconstructions. An experimental study in dogs. Clin. Oral Implants Res. 2019, 30, 1142-1154. [CrossRef]

183. Ferrari, D.S.; Piattelli, A.; Iezzi, G.; Faveri, M.; Rodrigues, J.A.; Shibli, J.A. Effect of lateral static load on immediately restored implants: Histologic and radiographic evaluation in dogs. Clin. Oral Implants Res. 2015, 26, e51-e56. [CrossRef] [PubMed]

184. Caneva, M.; Botticelli, D.; Salata, L.A.; Scombatti Souza, S.L.; Carvalho Cardoso, L.; Lang, N.P. Collagen membranes at immediate implants: A histomorphometric study in dogs. Clin. Oral Implants Res. 2010, 21, 891-897. [CrossRef]

185. Schwarz, F.; Mihatovic, I.; Shirakata, Y.; Becker, J.; Bosshardt, D.; Sculean, A. Treatment of soft tissue recessions at titanium implants using a resorbable collagen matrix: A pilot study. Clin. Oral Implants Res. 2014, 25, 110-115. [CrossRef]

186. Vierra, M.; Mau, L.P.; Huynh-Ba, G.; Schoolfield, J.; Cochran, D.L. A lateral ridge augmentation study to evaluate a synthetic membrane for guided bone regeneration: An experiment in the canine mandible. Clin. Oral Implants Res. 2016, 27, 73-82. [CrossRef]

187. Antunes, A.A.; Grossi-Oliveira, G.A.; Martins-Neto, E.C.; De Almeida, A.L.G.; Salata, L.A. Treatment of circumferential defects with osseoconductive xenografts of different porosities: A histological, histometric, resonance frequency analysis, and micro-ct study in dogs. Clin. Implant Dent. Relat. Res. 2013, 17, e202-e220. [CrossRef] [PubMed]

188. Benic, G.I.; Thoma, D.S.; Muñoz, F.; Sanz Martin, I.; Jung, R.E.; Hämmerle, C.H.F. Guided bone regeneration of peri-implant defects with particulated and block xenogenic bone substitutes. Clin. Oral Implants Res. 2016, 27, 567-576. [CrossRef]

189. Sivolella, S.; Bressan, E.; Salata, L.A.; Quiñones, M.E.; Lang, N.P.; Botticelli, D. Deproteinized bovine bone mineral particles and osseointegration of implants without primary bone contact: An experimental study in dogs. Clin. Oral Implants Res. 2014, 25, 296-303. [CrossRef]

190. Jung, U.-W.; Cha, J.-K.; Vignoletti, F.; Sanz, J.; Sanz, M. Simultaneous lateral bone augmentation and implant placement using a particulated synthetic bone substitute around chronic peri-implant dehiscence defects in dogs. J. Clin. Periodontol. 2017, 44, 1172-1180. [CrossRef] [PubMed]

191. Orti, V.; Bousquet, P.; Tramini, P.; Gaitan, C.; Mertens, B.; Cuisinier, F. Benefits of mineralized bone cortical allograft for immediate implant placement in extraction sites: An in vivo study in dogs. J. Periodontal Implant Sci. 2016, 46, 291-302. [CrossRef]

192. Doi, K.; Kubo, T.; Takeshita, R.; Kajihara, S.; Kato, S.; Kawazoe, Y.; Shiba, T.; Akagawa, Y. Inorganic polyphosphate adsorbed onto hydroxyapatite for guided bone regeneration: An animal study. Dent. Mater. J. 2014, 33, 179-186. [CrossRef]

193. Benic, G.I.; Joo, M.J.; Yoon, S.R.; Cha, J.K.; Jung, U.W. Primary ridge augmentation with collagenated xenogenic block bone substitute in combination with collagen membrane and rhBMP-2: A pilot histological investigation. Clin. Oral Implants Res. 2017, 28, 1543-1552. [CrossRef] [PubMed]

194. Cha, J.K.; Jung, U.W.; Thoma, D.S.; Hämmerle, C.H.F.; Jung, R.E. Osteogenic efficacy of BMP-2 mixed with hydrogel and bone substitute in peri-implant dehiscence defects in dogs: 16 weeks of healing. Clin. Oral Implants Res. 2018, 29, 300-308. [CrossRef]

195. Amara, H.; Lee, J.-W.; Kim, J.-J.; Kang, Y.-M.; Kang, E.-J.; Koo, K.-T. Influence of rhBMP-2 on Guided Bone Regeneration for Placement and Functional Loading of Dental Implants: A Radiographic and Histologic Study in Dogs. Int. J. Oral Maxillofac. Implants 2017, 32, e265-e267. [CrossRef]

196. Pan, H.; Han, J.J.; Park, Y.D.; Cho, T.H.; Hwang, S.J. Effect of sustained release of rhBMP-2 from dried and wet hyaluronic acid hydrogel carriers compared with direct dip coating of rhBMP-2 on peri-implant osteogenesis of dental implants in canine mandibles. J. Cranio-Maxillofacial Surg. 2016, 44, 116-125. [CrossRef] [PubMed]

197. Machtei, E.E.; Kim, D.M.; Karimbux, N.; Zigdon-Giladi, H. The use of endothelial progenitor cells combined with barrier membrane for the reconstruction of peri-implant osseous defects: An animal experimental study. J. Clin. Periodontol. 2016, 43, 289-297. [CrossRef]

198. Sánchez-Garcés, M.; Alvira-González, J.; Sánchez, C.; Cairó, J.; del Pozo, M.; Gay-Escoda, C. Bone Regeneration Using AdiposeDerived Stem Cells with Fibronectin in Dehiscence-Type Defects Associated with Dental Implants: An Experimental Study in a Dog Model. Int. J. Oral Maxillofac. Implants 2017, 32, e97-e106. [CrossRef] [PubMed] 
199. Han, X.; Liu, H.; Wang, D.; Su, F.; Zhang, Y.; Zhou, W.; Li, S.; Yang, R. alveolar bone regeneration around immediate implants using an injectable nHAC/CSH loaded with autogenic blood-acquired mesenchymal progenitor cells: An experimental study in the dog mandible. Clin. Implant Dent. Relat. Res. 2013, 15, 390-401. [CrossRef] [PubMed]

200. Song, D.; Huang, Y.; Van Dessel, J.; Shujaat, S.; Orhan, K.; Vangansewinkel, T.; Van den Eynde, K.; Lambrichts, I.; Roskams, T.; Politis, C.; et al. Effect of platelet-rich and platelet-poor plasma on peri-implant innervation in dog mandibles. Int. J. Implant Dent. 2019, 5. [CrossRef] [PubMed]

201. Huang, Y.; Li, Z.; Van Dessel, J.; Salmon, B.; Huang, B.; Lambrichts, I.; Politis, C.; Jacobs, R. Effect of platelet-rich plasma on peri-implant trabecular bone volume and architecture: A preclinical micro-CT study in beagle dogs. Clin. Oral Implants Res. 2019, 30, 1190-1199. [CrossRef]

202. Streckbein, P.; Kleis, W.; Buch, R.S.R.; Hansen, T.; Weibrich, G. Bone healing with or without platelet-rich plasma around four different dental implant surfaces in Beagle Dogs. Clin. Implant Dent. Relat. Res. 2014, 16, 479-486. [CrossRef]

203. De Sanctis, M.; Vignoletti, F.; Discepoli, N.; Muñoz, F.; Sanz, M. Immediate implants at fresh extraction sockets: An experimental study in the beagle dog comparing four different implant systems. Soft tissue findings. J. Clin. Periodontol. 2010, 37, 769-776. [CrossRef]

204. Negri, B.; Calvo-Guirado, J.L.; Maté Sánchez de Val, J.E.; Delgado Ruiz, R.A.; Ramírez Fernández, M.P.; Gómez Moreno, G.; Aguilar Salvatierra, A.; Guardia, J.; Muñoz Guzón, F. Biomechanical and Bone Histomorphological Evaluation of Two Surfaces on Tapered and Cylindrical Root Form Implants: An Experimental Study in Dogs. Clin. Implant Dent. Relat. Res. 2013, 15, 799-808. [CrossRef]

205. Calvo-Guirado, J.L.; Gomez Moreno, G.; Aguilar-Salvatierra, A.; Mate Sanchez de Val, J.E.; Abboud, M.; Nemcovsky, C.E. Bone remodeling at implants with different configurations and placed immediately at different depth into extraction sockets. Experimental study in dogs. Clin. Oral Implants Res. 2015, 26, 507-515. [CrossRef] [PubMed]

206. Caneva, M.; Salata, L.A.; de Souza, S.S.; Bressan, E.; Botticelli, D.; Lang, N.P. Hard tissue formation adjacent to implants of various size and configuration immediately placed into extraction sockets: An experimental study in dogs. Clin. Oral Implants Res. 2010, 21, 885-890. [CrossRef]

207. Chang, Y.Y.; Kim, S.H.; Park, K.O.; Yun, J.H. Effect of microthreads on coronal bone healing of narrow-diameter implants with reverse-tapered design in beagle dogs. Clin. Oral Implants Res. 2017, 28, 1532-1542. [CrossRef] [PubMed]

208. Choi, J.Y.; Moon, I.S.; Yun, J.H.; Park, K.H.; Huh, J.K.; Lee, D.W. Effects of thread size in the implant neck area on peri-implant hard and soft tissues: An animal study. Clin. Oral Implants Res. 2016, 27, 1187-1192. [CrossRef] [PubMed]

209. Igarashi, K.; Nakahara, K.; Kobayashi, E.; Watanabe, F.; Haga-Tsujimura, M. Hard and soft tissue responses to implant made of three different materials with microgrooved collar in a dog model. Dent. Mater. J. 2018, 37, 964-972. [CrossRef]

210. Mihatovic, I.; Golubovic, V.; Becker, J.; Schwarz, F. Bone tissue response to experimental zirconia implants. Clin. Oral Investig. 2017, 21, 523-532. [CrossRef] [PubMed]

211. El Awadly, T.A.; Wu, G.; Ayad, M.; Radi, I.A.W.; Wismeijer, D.; El Fetouh, H.A.; Osman, R.B. A Histomorphometric Study on Treated and Untreated Ceramic Filled PEEK Implants Versus Titanium Implants: Preclinical In Vivo Study. Clin. Oral Implant. Res. 2020, 31, 246-254. [CrossRef] [PubMed]

212. Lee, J.; Wen, H.; Battula, S.; Akella, R.; Collins, M.; Romanos, G. Outcome After Placement of Tantalum Porous Engineered Dental Implants in Fresh Extraction Sockets: A Canine Study. Int. J. Oral Maxillofac. Implants 2015, 30, 134-142. [CrossRef] [PubMed]

213. Lee, J.; Hurson, S.; Tadros, H.; Schüpbach, P.; Susin, C.; Wikesjö, U.M.E. Crestal remodelling and osseointegration at surfacemodified commercially pure titanium and titanium alloy implants in a canine model. J. Clin. Periodontol. 2012, 39, 781-788. [CrossRef]

214. Song, W.W.; Heo, J.H.; Lee, J.H.; Park, Y.M.; Kim, Y.D. Osseointegration of magnesium-incorporated sand-blasted acid-etched implant in the dog mandible: Resonance frequency measurements and histomorphometric analysis. Tissue Eng. Regen. Med. 2016, 13, 191-199. [CrossRef]

215. Qiao, S.; Cao, H.; Zhao, X.; Lo, H.; Zhuang, L.; Gu, Y.; Shi, J.; Liu, X.; Lai, H. Ag-plasma modification enhances bone apposition around titanium dental implants: An animal study in labrador dogs. Int. J. Nanomed. 2015, 10, 653-664. [CrossRef]

216. Simion, M.; Benigni, M.; Al-Hezaimi, K.; Kim, D. Early Bone Formation Adjacent to Oxidized and Machined Implant Surfaces: A Histologic Study. Int. J. Periodontics Restor. Dent. 2015, 35, 9-17. [CrossRef]

217. Choi, J.Y.; Jung, U.W.; Kim, C.S.; Jung, S.M.; Lee, I.S.; Choi, S.H. Influence of nanocoated calcium phosphate on two different types of implant surfaces in different bone environment: An animal study. Clin. Oral Implants Res. 2013, 24, 1018-1022. [CrossRef] [PubMed]

218. Schmitt, C.M.; Koepple, M.; Moest, T.; Neumann, K.; Weisel, T.; Schlegel, K.A. In vivo evaluation of biofunctionalized implant surfaces with a synthetic peptide (P-15) and its impact on osseointegration. A preclinical animal study. Clin. Oral Implants Res. 2016, 27, 1339-1348. [CrossRef] [PubMed]

219. Caram, S.; Huynh-Ba, G.; Schoolfield, J.; Jones, A.; Cochran, D.; Belser, U. Biologic Width Around Different Implant-Abutment Interface Configurations. A Radiographic Evaluation of the Effect of Horizontal Offset and Concave Abutment Profile in the Canine Mandible. Int. J. Oral Maxillofac. Implants 2014, 29, 1114-1122. [CrossRef] [PubMed]

220. López-López, P.J.; Mareque-Bueno, J.; Boquete-Castro, A.; Aguilar-Salvatierra Raya, A.; Martínez-González, J.M.; Calvo-Guirado, J.L. The effects of healing abutments of different size and anatomic shape placed immediately in extraction sockets on peri-implant hard and soft tissues. A pilot study in foxhound dogs. Clin. Oral Implants Res. 2016, 27, 90-96. [CrossRef] [PubMed] 
221. Rea, M.; Ricci, S.; Ghensi, P.; Lang, N.P.; Botticelli, D.; Soldini, C. Marginal healing using Polyetheretherketone as healing abutments: An experimental study in dogs. Clin. Oral Implants Res. 2017, 28, e46-e50. [CrossRef]

222. Blanco, J.; Caneiro, L.; Liñares, A.; Batalla, P.; Muñoz, F.; Ramos, I. Peri-implant soft tissue analyses comparing Ti and $\mathrm{ZrO}_{2}$ abutments: An animal study on beagle dogs. Clin. Oral Implants Res. 2016, 27, 1221-1226. [CrossRef] [PubMed]

223. Schwarz, F.; Mihatovic, I.; Golubovich, V.; Schär, A.; Sager, M.; Becker, J. Impact of abutment microstructure and insertion depth on crestal bone changes at nonsubmerged titanium implants with platform switch. Clin. Oral Implants Res. 2015, 26, 287-292. [CrossRef]

224. Alves, C.C.; Muñoz, F.; Cantalapiedra, A.; Ramos, I.; Neves, M.; Blanco, J. Marginal bone and soft tissue behavior following platform switching abutment connection/disconnection- a dog model study. Clin. Oral Implants Res. 2015, 26, 983-991. [CrossRef]

225. Bressan, E.; Lang, N.P.; Corazza, B.; Ricci, S.; Urrutia, Z.A.; Botticelli, D. The platform switching concept revisited. An experimental study in dogs. Clin. Oral Implants Res. 2014, 25, 1200-1206. [CrossRef]

226. Salomó-Coll, O.; Maté-Sánchez de Val, J.E.; Ramírez-Fernández, M.P.; Satorres-Nieto, M.; Gargallo-Albiol, J.; Calvo-Guirado, J.L. Osseoinductive elements for promoting osseointegration around immediate implants: A pilot study in the foxhound dog. Clin. Oral Implants Res. 2016, 27, e167-e175. [CrossRef]

227. Salomó-Coll, O.; Maté-Sánchez de Val, J.E.; Ramírez-Fernandez, M.P.; Hernández-Alfaro, F.; Gargallo-Albiol, J.; Calvo-Guirado, J.L. Topical applications of vitamin D on implant surface for bone-to-implant contact enhance: A pilot study in dogs part II. Clin. Oral Implants Res. 2016, 27, 896-903. [CrossRef]

228. Liao, J.; Wu, M.J.; Mu, Y.D.; Li, P.; Go, J. Impact of hyperbaric oxygen on tissue healing around dental implants in Beagles. Med. Sci. Monit. 2018, 24, 8150-8159. [CrossRef] [PubMed]

229. Fan, X.; Wang, Z.; Ji, P.; Bian, Y.; Lan, J. rgpA DNA Vaccine Induces Antibody Response and Prevents Alveolar Bone Loss in Experimental Peri-Implantitis. J. Periodontol. 2013, 84, 850-856. [CrossRef]

230. Guo, M.; Wang, Z.; Fan, X.; Bian, Y.; Wang, T.; Zhu, L.; Lan, J. kgp, rgpA, and rgpB DNA Vaccines Induce Antibody Responses in Experimental Peri-Implantitis. J. Periodontol. 2014, 85, 1575-1581. [CrossRef]

231. Hamp, S.E.; Lindberg, R. Histopathology of spontaneous periodontitis in dogs. J. Periodontal Res. 1977, 12, 46-54. [CrossRef]

232. Charalampakis, G.; Abrahamsson, I.; Carcuac, O.; Dahlén, G.; Berglundh, T. Microbiota in experimental periodontitis and peri-implantitis in dogs. Clin. Oral Implants Res. 2014, 25, 1094-1098. [CrossRef]

233. Zhu, B.; Meng, H.; Huang, B.; Chen, Z.B.; Lu, R. Detection of T. forsythia and other important bacteria in crestal and subcrestal implants with ligature-induced peri-implant infection in dogs. J. Periodontol. 2019, 90, 306-313. [CrossRef]

234. Seong, W.J.; Kotsakis, G.; Huh, J.K.; Jeong, S.C.; Nam, K.Y.; Kim, J.R.; Heo, Y.C.; Kim, H.C.; Zhang, L.; Evans, M.D.; et al. Clinical and microbiologic investigation of an expedited peri-implantitis dog model: An animal study. BMC Oral Health 2019, 19, 1-11. [CrossRef] [PubMed]

235. Madi, M.; Alagl, A.S. The Effect of Different Implant Surfaces and Photodynamic Therapy on Periodontopathic Bacteria Using TaqMan PCR Assay following Peri-Implantitis Treatment in Dog Model. Biomed Res. Int. 2018, 2018. [CrossRef]

236. Carcuac, O.; Abrahamsson, I.; Albouy, J.P.; Linder, E.; Larsson, L.; Berglundh, T. Experimental periodontitis and peri-implantitis in dogs. Clin. Oral Implants Res. 2013, 24, 363-371. [CrossRef] [PubMed]

237. Lin, X.; Liu, T.; Wu, G.; Zheng, Y.; Wismeijer, D.; Liu, Y. Peri-implantitis Induced by Stainless Steel Ligature in Beagle Dogs. Int. J. Periodontics Restorative Dent. 2017, 37, e170-e179. [CrossRef]

238. Park, S.Y.; Kim, K.H.; Rhee, S.H.; Lee, J.C.; Shin, S.Y.; Lee, Y.M.; Seol, Y.J. An immediate peri-implantitis induction model to study regenerative peri-implantitis treatments. Clin. Oral Implants Res. 2017, 28, 36-42. [CrossRef] [PubMed]

239. Schwarz, F.; Mihatovic, I.; Golubovic, V.; Bradu, S.; Sager, M.; Becker, J. Impact of plaque accumulation on the osseointegration of titanium-zirconium alloy and titanium implants. A histological and immunohistochemical analysis. Clin. Oral Implants Res. 2015, 26, 1281-1287. [CrossRef] [PubMed]

240. Roehling, S.; Gahlert, M.; Janner, S.; Meng, B.; Woelfler, D.D.S.H.; Cochran, D.L. Ligature-Induced Peri-implant Bone Loss Around Loaded Zirconia and Titanium implants. Int. J. Oral. Maxillofac. Implants 2019, 34, 357-365. [CrossRef]

241. Yang, H.W.; Tang, X.S.; Tian, Z.W.; Wang, Y.; Yang, W.Y.; Hu, J.Z. Effects of nano-hydroxyapatite/ polyetheretherketone-coated, sandblasted, large-grit, and acid-etched implants on inflammatory cytokines and osseointegration in a peri-implantitis model in beagle dogs. Med. Sci. Monit. 2017, 23, 4601-4611. [CrossRef] [PubMed]

242. Morelli, F.; Apaza Alccayhuaman, K.A.; Viganò, P.; Bengazi, F.; Urbizo, J.; Cesaretti, G.; Botticelli, D. Peri-implantitis at implants with different diameters: A pilot study in dogs. Int. J. Implant Dent. 2019, 5, 21. [CrossRef]

243. Yamamoto, A.; Tanabe, T. Treatment of Peri-implantitis Around TiUnite-Surface Implants Using Er:YAG Laser Microexplosions. Int. J. Periodontics Restor. Dent. 2013, 33, 21-29. [CrossRef]

244. Ramos, U.D.; Suaid, F.A.; Wikesjö, U.M.E.; Susin, C.; Taba, M.; Novaes, A.B. Comparison between two antimicrobial protocols with or without guided bone regeneration in the treatment of peri-implantitis. A histomorphometric study in dogs. Clin. Oral Implants Res. 2017, 28, 1388-1395. [CrossRef] [PubMed]

245. Carcuac, O.; Abrahamsson, I.; Charalampakis, G.; Berglundh, T. The effect of the local use of chlorhexidine in surgical treatment of experimental peri-implantitis in dogs. J. Clin. Periodontol. 2015, 42, 196-203. [CrossRef]

246. Levin, L.; Barbu, H.; Kurgan, S.; Comăneanu, R.M.; Referendaru, D.; Lorean, A. Evaluation of $0.2 \%$ delmopinol mouth rinse for prevention of peri-implant mucositis and peri-implantitis: A randomized controlled canine study. Clin. Implant Dent. Relat. Res. 2019, 21, 46-51. [CrossRef] 
247. Shi, Q.; Song, K.; Zhou, X.; Xiong, Z.; Du, T.; Lu, X.; Cao, Y. Effects of non-equilibrium plasma in the treatment of ligature-induced peri-implantitis. J. Clin. Periodontol. 2015, 42, 478-487. [CrossRef]

248. Xu, L.; Sun, X.; Bai, J.; Jiang, L.; Wang, S.; Zhao, J.; Xia, L.; Zhang, X.; Wen, J.; Li, G.; et al. Reosseointegration Following Regenerative Therapy of Tissue-Engineered Bone in a Canine Model of Experimental Peri-Implantitis. Clin. Implant Dent. Relat. Res. 2016, 18, 379-391. [CrossRef] [PubMed]

249. Oz, H.; Puleo, D. Animal models for periodontal disease. J Biomed Biotechnol 2011, 2011, 754857. [CrossRef] [PubMed]

250. Hytönen, M.K.; Lohi, H. Canine models of human rare disorders. Rare Dis. 2016, 4, e1241362. [CrossRef] [PubMed]

251. Kalemaj, Z.; Scarano, A.; Valbonetti, L.; Rapone, B.; Grassi, F. Bone Response to Four Dental Implants with Different Surface Topographies: A Histologic and Histometric Study in Minipigs. Int. J. Periodontics Restorative Dent. 2016, 745-754. [CrossRef] [PubMed]

252. Del Fabbro, M.; Taschieri, S.; Canciani, E.; Addis, A.; Musto, F.; Weinstein, R.; Dellavia, C. Osseointegration of Titanium Implants with Different Rough Surfaces: A Histologic and Histomorphometric Study in an Adult Minipig Model. Implant Dent. 2017, 26, 357-366. [CrossRef] [PubMed]

253. Schierano, G.; Mussano, F.; Faga, M.G.; Menicucci, G.; Manzella, C.; Sabione, C.; Genova, T.; Von Degerfeld, M.M.; Peirone, B.; Cassenti, A.; et al. An alumina toughened zirconia composite for dental implant application: In vivo animal results. Biomed Res. Int. 2015, 2015. [CrossRef] [PubMed]

254. Schorn, L.; Sproll, C.; Ommerborn, M.; Naujoks, C.; Kübler, N.R.; Depprich, R. Vertical bone regeneration using rhBMP-2 and VEGF. Head Face Med. 2017, 13, 1-11. [CrossRef]

255. Erdogan, Ö.; Üstün, Y.; Tatli, U.; Damlar, I.; Daglioglu, K. A pig model for the histomorphometric evaluation of hard tissue around dental implants. J. Oral Implantol. 2013, 39, 551-557. [CrossRef] [PubMed]

256. Moest, T.; Koehler, F.; Prechtl, C.; Schmitt, C.; Watzek, G.; Schlegel, K.A. Bone formation in peri-implant defects grafted with microparticles: A pilot animal experimental study. J. Clin. Periodontol. 2014, 41, 990-998. [CrossRef]

257. Mehl, C.; Becker, S.T.; Acil, Y.; Harder, S.; Wiltfang, J.; Dabbagh-Afrouz, A.A.; De Buhr, W.; Kern, M. Impact of vertical loading on the implant-bone interface. Clin. Oral Implants Res. 2013, 24, 949-956. [CrossRef]

258. Naujokat, H.; Harder, S.; Schulz, L.Y.; Wiltfang, J.; Flörke, C.; Açil, Y. Surface conditioning with cold argon plasma and its effect on the osseointegration of dental implants in miniature pigs. J. Cranio-Maxillofacial Surg. 2019, 47, 484-490. [CrossRef]

259. Cardoso, M.; de Rycker, J.; Chaudhari, A.; Duyck, J. Titanium implant functionalization with phosphate-coating polymers may favor in vivo osseointegration. J. Clin. Periodontol. 2016, 38, 42-49. [CrossRef]

260. Cardoso, M.; Chaudhari, A.; Yoshihara, K.; Mesquita, M.; Yoshida, Y.; Van Meerbeek, B.; Vandamme, K.; Duyck, J. Phosphorylated Pullulan Coating Enhances Titanium Implant Osseointegration in a Pig Model. Int. J. Oral Maxillofac. Implants 2017, 32, 282-290. [CrossRef] [PubMed]

261. Ramazanoglu, M.; Lutz, R.; Rusche, P.; Trabzon, L.; Kose, G.T.; Prechtl, C.; Schlegel, K.A. Bone response to biomimetic implants delivering BMP-2 and VEGF: An immunohistochemical study. J. Cranio-Maxillofacial Surg. 2013, 41, 826-835. [CrossRef]

262. Möller, B.; Terheyden, H.; Ail, Y.; Purcz, N.M.; Hertrampf, K.; Tabakov, A.; Behrens, E.; Wiltfang, J. A comparison of biocompatibility and osseointegration of ceramic and titanium implants: An in vivo and in vitro study. Int. J. Oral Maxillofac. Surg. 2012, 41, 638-645. [CrossRef] [PubMed]

263. Vivan Cardoso, M.; Vandamme, K.; Chaudhari, A.; De Rycker, J.; Van Meerbeek, B.; Naert, I.; Duyck, J. Dental Implant Macro-Design Features Can Impact the Dynamics of Osseointegration. Clin. Implant Dent. Relat. Res. 2015, 17, 639-645. [CrossRef]

264. Mehl, C.; Gaßling, V.; Schultz-Langerhans, S.; Açil, Y.; Bähr, T.; Wiltfang, J.; Kern, M. Influence of Four Different Abutment Materials and the Adhesive Joint of Two-Piece Abutments on Cervical Implant Bone and Soft Tissue. Int. J. Oral Maxillofac. Implants 2016, 31, 1264-1272. [CrossRef] [PubMed]

265. Nonhoff, J.; Moest, T.; Schmitt, C.M.; Weisel, T.; Bauer, S.; Schlegel, K.A. Establishment of a new pull-out strength testing method to quantify early osseointegration-An experimental pilot study. J. Cranio-Maxillofacial Surg. 2015, 43, 1966-1973. [CrossRef] [PubMed]

266. Lutz, R.; Sendlbeck, C.; Wahabzada, H.; Tudor, C.; Prechtl, C.; Schlegel, K.A. Periosteal elevation induces supracortical periimplant bone formation. J. Cranio-Maxillofacial Surg. 2017, 45, 1170-1178. [CrossRef]

267. Schlegel, K.A.; Prechtl, C.; Möst, T.; Seidl, C.; Lutz, R.; von Wilmowsky, C. Osseointegration of SLActive implants in diabetic pigs. Clin. Oral Implants Res. 2013, 24, 128-134. [CrossRef]

268. Brockmeyer, P.; Krohn, S.; Thiemann, C.; Schulz, X.; Kauffmann, P.; Tröltzsch, M.; Schlottig, F.; Schliephake, H.; Gruber, R.M. Primary stability and osseointegration of dental implants in polylactide modified bone-A pilot study in Goettingen minipigs. J. Cranio-Maxillofacial Surg. 2016, 44, 1095-1103. [CrossRef]

269. Coelho, P.G.; Pippenger, B.; Tovar, N.; Koopmans, S.J.; Plana, N.M.; Graves, D.T.; Engebretson, S.; van Beusekom, H.M.M.; Oliveira, P.G.F.P.; Dard, M. Effect of Obesity or Metabolic Syndrome and Diabetes on Osseointegration of Dental Implants in a Miniature Swine Model: A Pilot Study. J. Oral Maxillofac. Surg. 2018, 76, 1677-1687. [CrossRef]

270. Tan, N.; Liu, X.; Cai, Y.; Zhang, S.; Jian, B.; Zhou, Y.; Xu, X.; Ren, S.; Wei, H.; Song, Y. The influence of direct laser metal sintering implants on the early stages of osseointegration in diabetic mini-pigs. Int. J. Nanomed. 2017, 12, 5433-5442. [CrossRef]

271. Vasak, C.; Busenlechner, D.; Schwarze, U.Y.; Leitner, H.F.; Munoz Guzon, F.; Hefti, T.; Schlottig, F.; Gruber, R. Early bone apposition to hydrophilic and hydrophobic titanium implant surfaces: A histologic and histomorphometric study in minipigs. Clin. Oral Implants Res. 2014, 25, 1378-1385. [CrossRef] [PubMed] 
272. Stubinger, S.; Bucher, R.; Kronen, P.; Schlottig, F.; Rechenberg, B. von Ligature-Induced Peri-Implantitis in Minipigs Revisited. Periodontics Prosthodont. 2016, 02, 1-5. [CrossRef]

273. Eom, T.-G.; Kim, H.; Jeon, G.-R.; Yun, M.-J.; Huh, J.-B.; Jeong, C.-M. Effects of Different Implant Osteotomy Preparation Sizes on Implant Stability and Bone Response in the Minipig Mandible. Int. J. Oral Maxillofac. Implants 2016, 997-1006. [CrossRef] [PubMed]

274. Lazić, Z.; Golubović, M.; Marković, A.; Šćepanović, M.; Mišić, T.; Vlahović, Z. Immunohistochemical analysis of blood vessels in peri-implant mucosa: A comparison between mini-incision flapless and flap surgeries in domestic pigs. Clin. Oral Implants Res. 2015, 26, 775-779. [CrossRef] [PubMed]

275. Pérez-Albacete Martínez, C.; Vlahović, Z.; Šćepanović, M.; Videnović, G.; Barone, A.; Calvo-Guirado, J.L. Submerged flapless technique vs. conventional flap approach for implant placement: Experimental domestic pig study with 12-month follow-up. Clin. Oral Implants Res. 2016, 27, 964-968. [CrossRef] [PubMed]

276. Stricker, A.; Fleiner, J.; Dard, M.; Voss, P.; Sauerbier, S.; Bosshardt, D.D. Evaluation of a new experimental model to study bone healing after ridge expansion with simultaneous implant placement-a pilot study in minipigs. Clin. Oral Implants Res. 2014, 25, 1265-1272. [CrossRef]

277. Friedmann, A.; Friedmann, A.; Grize, L.; Obrecht, M.; Dard, M. Convergent methods assessing bone growth in an experimental model at dental implants in the minipig. Ann. Anat. 2014, 196, 100-107. [CrossRef] [PubMed]

278. Verket, A.; Lyngstadaas, S.P.; Rønold, H.J.; Wohlfahrt, J.C. Osseointegration of dental implants in extraction sockets preserved with porous titanium granules-An experimental study. Clin. Oral Implants Res. 2014, 25, 100-108. [CrossRef]

279. Verket, A.; Müller, B.; Wohlfahrt, J.C.; Lyngstadaas, S.P.; Ellingsen, J.E.; Jostein Haugen, H.; Tiainen, H. TiO2 scaffolds in peri-implant dehiscence defects: An experimental pilot study. Clin. Oral Implants Res. 2015, 1-7. [CrossRef]

280. Catros, S.; Wen, B.; Schleier, P.; Shafer, D.; Dard, M.; Obrecht, M.; Freilich, M.; Kuhn, L. Use of a Perforated Scaffold-Retaining Abutment to Achieve Vertical Bone Regeneration Around Dental Implants in the Minipig. Int. J. Oral Maxillofac. Implants 2013, 28, 432-443. [CrossRef]

281. Korn, P.; Schulz, M.; Hintze, V.; Stadlinger, B. Chondroitin sulfate and sulfated hyaluronan containing collagen coatings of titanium implants influence peri-implant bone formation in a minipig model. J Biomed. Mater Res. 2014, 2-31. [CrossRef]

282. Schulz, M.C.; Korn, P.; Stadlinger, B.; Range, U.; Möller, S.; Becher, J.; Schnabelrauch, M.; Mai, R.; Scharnweber, D.; Eckelt, U.; et al. Coating with artificial matrices from collagen and sulfated hyaluronan influences the osseointegration of dental implants. $J$. Mater. Sci. Mater. Med. 2014, 25, 247-258. [CrossRef]

283. Stadlinger, B.; Hintze, V.; Bierbaum, S.; Möller, S.; Schulz, M.C.; Mai, R.; Kuhlisch, E.; Heinemann, S.; Scharnweber, D.; Schnabelrauch, M.; et al. Biological functionalization of dental implants with collagen and glycosaminoglycans-A comparative study. J. Biomed. Mater. Res. Part B Appl. Biomater. 2012, 100, 331-341. [CrossRef]

284. Cochran, D.; Stavropoulos, A.; Obrecht, M.; Pippenger, B.; Dard, M. A Comparison of Tapered and Nontapered Implants in the Minipig. Int. J. Oral Maxillofac. Implants 2016, 31, 1341-1347. [CrossRef]

285. Vlahović, Z.; Marković, A.; Lazić, Z.; Šćepanović, M.; Đinić, A.; Kalanović, M. Histopathological comparative analysis of periimplant bone inflammatory response after dental implant insertion using flap and flapless surgical technique. An experimental study in pigs. Clin. Oral Implants Res. 2017, 28, 1067-1073. [CrossRef]

286. Huang, M.S.; Chen, L.K.; Ou, K.L.; Cheng, H.Y.; Wang, C.S. Rapid Osseointegration of Titanium Implant with Innovative Nanoporous Surface Modification: Animal Model and Clinical Trial. Implant Dent. 2015, 24, 441-447. [CrossRef]

287. Chiang, H.J.; Hsu, H.J.; Peng, P.W.; Wu, C.Z.; Ou, K.L.; Cheng, H.Y.; Walinski, C.J.; Sugiatno, E. Early bone response to machined, sandblasting acid etching (SLA) and novel surface-functionalization (SLAffinity) titanium implants: Characterization, biomechanical analysis and histological evaluation in pigs. J. Biomed. Mater. Res. Part A 2016, 104, 397-405. [CrossRef]

288. Ou, K.L.; Weng, C.C.; Wu, C.C.; Lin, Y.H.; Chiang, H.J.; Yang, T. Sen; Wang, J.; Yen, Y.; Cheng, H.Y.; Sugiatno, E. Research of StemBios cell therapy on dental implants containing nanostructured surfaces: Biomechanical behaviors, microstructural characteristics, and clinical trial. Implant Dent. 2016, 25, 63-73. [CrossRef]

289. Rodella, L.F.; Favero, G.; Sala, L.; Buffoli, B.; Castelli, G.; Belloni, V.; Paganelli, C.; Rezzani, R. A comparative pilot study of two dental implant metals in a pig model. Implant Dent. 2010, 19, 532-538. [CrossRef] [PubMed]

290. Schliephake, H.; Hefti, T.; Schlottig, F.; Gédet, P.; Staedt, H. Mechanical anchorage and peri-implant bone formation of surfacemodified zirconia in minipigs. J. Clin. Periodontol. 2010, 37, 818-828. [CrossRef]

291. Anchieta, R.B.; Baldassarri, M.; Guastaldi, F.; Tovar, N.; Janal, M.N.; Gottlow, J.; Dard, M.; Jimbo, R.; Coelho, P.G. Mechanical property assessment of bone healing around a titanium-zirconium alloy dental implant. Clin. Implant Dent. Relat. Res. 2014, 913-919. [CrossRef]

292. Liñares, A.; Muñoz, F.; Permuy, M.; Dard, M.; Blanco, J. Soft tissue histomorphology at implants with a transmucosal modified surface. A study in minipigs. Clin. Oral Implants Res. 2015, 26, 996-1005. [CrossRef]

293. Mueller, C.K.; Thorwarth, M.; Schultze-Mosgau, S. Influence of insertion protocol and implant shoulder design on inflammatory infiltration and gene expression in peri-implant soft tissue during nonsubmerged dental implant healing. Oral Surg. Oral Med. Oral Pathol. Oral Radiol. Endodontology 2010, 109, e11-e19. [CrossRef] [PubMed]

294. Sivan-Gildor, A.; Machtei, E.E.; Gabay, E.; Frankenthal, S.; Levin, L.; Suzuki, M.; Coelho, P.G.; Zigdon-Giladi, H. Novel Implant Design Improves Implant Survival in Multirooted Extraction Sites: A Preclinical Pilot Study. J. Periodontol. 2014, 85, 1458-1463. [CrossRef] 
295. Farronato, D.; Santoro, G.; Canullo, L.; Botticelli, D.; Maiorana, C.; Lang, N.P. Establishment of the epithelial attachment and connective tissue adaptation to implants installed under the concept of "platform switching": A histologic study in minipigs. Clin. Oral Implants Res. 2012, 23, 90-94. [CrossRef] [PubMed]

296. de Oliveira Silva, R.; Passador, F.; Caria, P.H.F. Twist removal of healed vs. nonhealed implants—a mechanical and histological study in mini pigs. Int. J. Implant Dent. 2016, 2. [CrossRef]

297. Mehl, C.; Kern, M.; Neumann, F.; Bähr, T.; Wiltfang, J.; Gassling, V. Effect of ultraviolet photofunctionalization of dental titanium implants on osseointegration. J. Zhejiang Univ. Sci. B 2018, 19, 525-534. [CrossRef]

298. Choi, M.; Culjat, M.O.; Singh, R.S.; White, S.N. Ultrasound imagery for dental implant diagnosis and treatment planning in a porcine model. J. Prosthet. Dent. 2012, 108, 344-353. [CrossRef]

299. Dos Santos Corpas, L.; Jacobs, R.; Quirynen, M.; Huang, Y.; Naert, I.; Duyck, J. Peri-implant bone tissue assessment by comparing the outcome of intra-oral radiograph and cone beam computed tomography analyses to the histological standard. Clin. Oral Implants Res. 2011, 22, 492-499. [CrossRef]

300. Elian, N.; Bloom, M.; Dard, M.; Cho, S.C.; Trushkowsky, R.D.; Tarnow, D. Radiological and micro-computed tomography analysis of the bone at dental implants inserted 2, 3 and $4 \mathrm{~mm}$ apart in a minipig model with platform switching incorporated. Clin. Oral Implants Res. 2014, 25, 1-8. [CrossRef]

301. Korn, P.; Elschner, C.; Schulz, M.C.; Range, U.; Mai, R.; Scheler, U. MRI and dental implantology: Two which do not exclude each other. Biomaterials 2015, 53, 634-645. [CrossRef] [PubMed]

302. Vlahović, Z.; Mihailović, B.; Lazić, Z.; Golubović, M. Comparative radiographic and resonance frequency analyses of the peri-implant tissue after dental implants placement using flap and flapeless techniques: An experimental study on domestic pigs. Vojnosanit. Pregl. 2013, 70, 586-594. [CrossRef] [PubMed]

303. Norden, C. Experimental osteomyelitis. I. A description of the model. J. Infect. Dis. 1970, 122, 410-418. [CrossRef]

304. An, Y. Animal models of orthopedic implant infection. J. Invest. Surg. 1998, 139-146. [CrossRef]

305. Caneva, M.; Lang, N.P. Bone healing at bicortically installed implants with different surface configurations. An experimental study in rabbits. Clin. Oral Implants Res. 2014, 293-300. [CrossRef]

306. Gehrke, S.A.; Dedavid, B.A.; Aramburú, J.S.; Pérez-Díaz, L.; Guirado, J.L.C.; Canales, P.M.; De Aza, P.N. Effect of Different Morphology of Titanium Surface on the Bone Healing in Defects Filled Only with Blood Clot: A New Animal Study Design. Biomed Res. Int. 2018, 2018, 4265474. [CrossRef]

307. Martins, R.; Cestari, T.M.; Arantes, R.V.N.; Santos, P.S.; Taga, R.; Carbonari, M.J.; Oliveira, R.C. Osseointegration of zirconia and titanium implants in a rabbit tibiae model evaluated by microtomography, histomorphometry and fluorochrome labeling analyses. J. Periodontal Res. 2018, 53, 210-221. [CrossRef]

308. Kämmerer, P.W.; Palarie, V.; Schiegnitz, E.; Hagmann, S.; Alshihri, A.; Al-Nawas, B. Vertical osteoconductivity and early bone formation of titanium-zirconium and titanium implants in a subperiosteal rabbit animal model. Clin. Oral Implants Res. 2014, 25, 774-780. [CrossRef]

309. Liu, Y.; Zhou, Y.; Jiang, T.; Liang, Y.-D.; Zhang, Z.; Wang, Y.-N. Evaluation of the osseointegration of dental implants coated with calcium carbonate: An animal study. Int. J. Oral Sci. 2017, 9, 133-138. [CrossRef] [PubMed]

310. Yang, D.H.; Moon, S.W.; Lee, D.-W. Surface Modification of Titanium with BMP-2/GDF-5 by a Heparin Linker and Its Efficacy as a Dental Implant. Int. J. Mol. Sci. 2017, 18, 229. [CrossRef] [PubMed]

311. Thiem, D.G.; Adam, M.; Ganz, C.; Gerber, T. The implant surface and its role in affecting the dynamic processes of bone remodeling by means of distance osteogenesis: A comparative in vivo study. JOMI 2018, 1-20. [CrossRef]

312. Duyck, J.; Roeseems, R.; Vandamme, K. Effect of insertion torque on titanium implant osseointegration: An animal experimental study. Clin. Oral Implants Res. 2013, 191-196. [CrossRef]

313. Sergio, A.G.; Giovanni Wiel, M. Biomechanical evaluation of dental implants with three different designs: Removal torque and resonance frequency analysis in rabbits. Ann. Anat. 2014, 119, 30-35. [CrossRef]

314. Vivan Cardoso, M.; Chaudhari, A.; Yoshida, Y.; Van Meerbeek, B.; Naert, I.; Duyck, J.; Polymers, B. tissue response to implant surfaces functionalized with phosphate-containing; Authors' Bone tissue response to implant surfaces functionalized with phosphate-containing polymers. Clin. Oral Implants Res. 2012, 91-100. [CrossRef]

315. Halldin, A.; Jimbo, R.; Johansson, C.B.; Wennerberg, A.; Jacobsson, M.; Albrektsson, T.; Hansson, S. Implant Stability and Bone Remodeling after 3 and 13 Days of Implantation with an Initial Static Strain. Clin. Implant Dent. Relat. Res. 2014, 16, 383-393. [CrossRef]

316. Landazuri-Del Barrio, R.A.; Nunes de Paula, W.; Spin-Neto, R.; Chaves de Souza, J.A.; Pimentel Lopes de Oliveira, G.J.; Marcantonio-Junior, E. Effect of 2 Different Drilling Speeds on the Osseointegration of Implants Placed with Flapless Guided Surgery: A Study in Rabbits. Implant Dent. 2017, 26, 882-887. [CrossRef]

317. Lee, J.-W.; Kim, S.-G.; Kim, J.-Y.; Lee, Y.-C.; Choi, J.-Y.; Dragos, R.; Rotaru, H. Restoration of a peri-implant defect by platelet-rich fibrin. Oral Surg. Oral Med. Oral Pathol. Oral Radiol. 2012, 113, 459-463. [CrossRef] [PubMed]

318. Cohen, D.J.; Scott, K.M.; Kulkarni, A.N.; Wayne, J.S.; Boyan, B.D.; Schwartz, Z. Acellular mineralized allogenic block bone graft does not remodel during the 10 weeks following concurrent implant placement in a rabbit femoral model. Clin. Oral Implants Res. 2020, 31, 37-48. [CrossRef] 
319. Casap, N.; Laster, Z.; Laviv, D.M.D.A.; Debecco, D.M.D.M. Recombinant Human Bone Morphogenetic Protein-2 Confined by an Imperforate Titanium Shell over High-Profile Dental Implants in Rabbit Tibiae: A Pilot Bone Augmentation Study. Int. J. Oral Maxillofac. Implants 2013. [CrossRef]

320. Oki, Y.; Doi, K.; Makihara, Y.; Kubo, T.; Oue, H.; Tsuga, K. Intermittent administration of parathyroid hormone enhances primary stability of dental implants in a bone-reduced rabbit model. J. Oral Sci. 2016, 58, 241-246. [CrossRef]

321. Carvalho, C.; Carvalho, L.; Costa, L.; Sá, M.; Figueiredo, C.; Azevedo, A. Titanium implants: A removal torque study in osteopenic rabbits. Indian J. Dent. Res. 2010, 21, 349-352. [CrossRef] [PubMed]

322. Martin-monge, E.; Tresguerres, D.D.S.I.F.; Clemente, C.; Tresguerres, D.D.S.J.A.F. Local Application of Growth Hormone to Enhance Osseointegration in Osteoporotic Bones: A Morphometric and Densitometric Study. Int. J. Oral Maxillofac. Implants 2017, 751-758. [CrossRef]

323. Almagro, M.I.; Roman-Blas, J.A.; Bellido, M.; Castañeda, S.; Cortez, R.; Herrero-Beaumont, G. PTH [1-34] enhances bone response around titanium implants in a rabbit model of osteoporosis. Clin. Oral Implants Res. 2013, 24, 1027-1034. [CrossRef]

324. Dündar, S.; Yaman, F.; Ozupek, M.F.; Saybak, A.; Gul, M.; Asutay, F.; Kirtay, M.; Ozercan, I.H. The effects of high-fat diet on implant osseointegration: An experimental study. J. Korean Assoc. Oral Maxillofac. Surg. 2016, 42, 187-192. [CrossRef] [PubMed]

325. Li, J.Y.; Pow, E.H.N.; Zheng, L.W.; Ma, L.; Kwong, D.L.W.; Cheung, L.K. Dose-dependent effect of radiation on titanium implants: A quantitative study in rabbits. Clin. Oral Implants Res. 2014, 25, 260-265. [CrossRef]

326. An, Y.H.; Kang, Q.K.; Arciola, C.R. Animal models of osteomyelitis. Int. J. Artif. Organs 2006, 29, 407-420. [CrossRef]

327. Stubinger, S.; Dard, M. The Rabbit as Experimental Model for Research in Implant. J. Investig. Surg. 2013, 266-282. [CrossRef]

328. Stoker, N.G.; Epker, B.N. Age Changes in Endosteal Bone Remodeling and Balance in the Rabbit. J. Dent. Res. 1970, 1570-1574. [CrossRef]

329. Cai, W.X.; Ma, L.; Zheng, L.W.; Kruse-Gujer, A.; Stübinger, S.; Lang, N.P.; Zwahlen, R.A. Influence of non-steroidal antiinflammatory drugs (NSAIDs) on osseointegration of dental implants in rabbit calvaria. Clin. Oral Implants Res. 2015, 26, 478-483. [CrossRef]

330. Wyss, F.; Mu ller, J.; Clauss, M.; Kircher, P.; Geyer, H.; Rechenberg, B.; Hatt, J.-M. Measuring Rabbit (Oryctolagus cuniculus) Tooth Growth and Eruption by Fluorescence Markers and Bur Marks. J. Vet. Dent. 2016, 33, 39-46. [CrossRef]

331. Popoff, S.N.; Marks, S.C., Jr. Relationship of abnormalities in dental and skeletal development in the osteopetrotic (os) rabbit. J. Oral Pathol. Med. 1990, 19, 5-12. [CrossRef]

332. Hedenqvist, P.; Trbakovic, A.; Thor, A.; Ley, C.; Ekman, S.; Jensen-Waern, M. Carprofen neither reduces postoperative facial expression scores in rabbits treated with buprenorphine nor alters long term bone formation after maxillary sinus grafting. Res. Vet. Sci. 2016, 107, 123-131. [CrossRef]

333. Thoma, D.S.; Yoon, S.-R.; Cha, J.-K.; Lim, H.-C.; Lee, J.-S.; Choi, S.-H.; Jung, U.-W. Sinus floor elevation using implants coated with recombinant human bone morphogenetic protein-2: Micro-computed tomographic and histomorphometric analyses. Clin. Oral Investig. 2018, 22, 829-837. [CrossRef]

334. Trbakovic, A.; Hedenqvist, P.; Mellgren, T.; Ley, C.; Hilborn, J.; Ossipov, D.; Ekman, S.; Johansson, C.B.; Jensen-Waern, M.; Thor, A. A new synthetic granular calcium phosphate compound induces new bone in a sinus lift rabbit model. J. Dent. 2018, 70, 31-39. [CrossRef]

335. Park, S.-H.; Choi, H.; Lee, S.-B.; Zhang, C.; Otgonbold, J.; Cho, J.-G.; Han, J.S. A rabbit maxillary sinus model with simultaneous customized-implant placement: Comparative microscopic analysis for the evaluation of surface-treated implants. Microsc. Res. Tech. 2015, 78, 697-706. [CrossRef]

336. Schiegnitz, E.; Palarie, V.; Nacu, V.; Al-Nawas, B.; Kämmerer, P.W. Vertical Osteoconductive Characteristics of Titanium Implants with Calcium-Phosphate-Coated Surfaces-A Pilot Study in Rabbits. Clin. Implant Dent. Relat. Res. 2014, 16, 194-201. [CrossRef]

337. Yu, Y.; Zhu, W.; Xu, L.; Ming, P.; Shao, S.; Qiu, J. Osseointegration of titanium dental implant under fluoride exposure in rabbits: Micro-CT and histomorphometry study. Clin. Oral Implants Res. 2019, 30, 1038-1048. [CrossRef] [PubMed]

338. Zhu, X.; Deng, T.; Pang, J.; Liu, B.K. Effect of High Positive Acceleration (+Gz) Environment on Dental Implant Osseointegration:A Preliminary Animal Study. Biomed envir Sci. 2019, 32, 687-698.

339. Pinheiro, F.A.L.; Mourão, C.F. de A.B.; Diniz, V.S.; Silva, P.C.; Meirelles, L.; Santos Junior, E.; Schanaider, A. In-vivo bone response to titanium screw implants anodized in sodium sulfate. Acta Cir. Bras. 2014, 29, 376-382. [CrossRef] [PubMed]

340. Kang, S.; Park, J.; Kim, I.; Lee, W.; Kim, H. Evaluation of apically positioned dental implants with a sandblasted with large grit and acid-etched surface 1 day after initial placement using micro-CT images and nondecalcified tissue slide images in a rabbit model Authors and Affiliations. JOMI 2019, 34, 1078-1083. [CrossRef]

341. Shen, L.; Meng, L.; Wang, X.; Jiang, H.; Wang, S. Establishment of animal model with peri-implantitis after immediate implantation in rabbits. Shanghai Kou Qiang Yi Xue 2015, 24, 37-40. [PubMed]

342. Wen, B.; Li, Z.; Nie, R.; Liu, C.; Zhang, P.; Miron, R.J.; Dard, M.M. Influence of biphasic calcium phosphate surfaces coated with Enamel Matrix Derivative on vertical bone growth in an extra-oral rabbit model. Clin. Oral Implants Res. 2016, 27, $1297-1304$. [CrossRef]

343. Alenezi, A.; Galli, S.; Atefyekta, S.; Andersson, M.; Wennerberg, A. Osseointegration effects of local release of strontium ranelate from implant surfaces in rats. J. Mater. Sci. Mater. Med. 2019, 30, 1-12. [CrossRef] [PubMed] 
344. Schliephake, H.; Rublack, J.; Förster, A.; Schwenzer, B.; Reichert, J.; Scharnweber, D. Functionalization of titanium implants using a modular system for binding and release of VEGF enhances bone-implant contact in a rodent model. J. Clin. Periodontol. 2015, 42, 302-310. [CrossRef] [PubMed]

345. Eduardo, C.; Mafra, S.; Sirolli, M.; Cabral, M. Effect of Different Doses of Synthetic Parathyroid Hormone ( 1-34 ) on Bone around Implants: A Preclinical Rat Model. Brazilian Dent. J. 2019, 30, 43-46.

346. Cirano, F.; Pimentel, S.; Casati, M.; Correa, M.; Ribeiro, F. Effect of curcumin on bone tissue in the diabetic rat: Repair of peri-implant and critical-sized defects. Oral Maxillofac. Surg. 2018, 47, 1495-1503. [CrossRef] [PubMed]

347. de Oliveira, M.A.; Asahi, D.A.; Silveira, C.A.E.; Lima, L.A.P.A.; Glick, M.; Gallottini, M. The effects of zoledronic acid and dexamethasone on osseointegration of endosseous implants: Histological and histomorphometrical evaluation in rats. Clin. Oral Implants Res. 2015, 26, e17-e21. [CrossRef] [PubMed]

348. Rybaczek, T.; Tangl, S.; Reinhard, G.; Kuchler, U. The Effect of Parathyroid Hormone on Osseointegration in Insulin-Treated Diabetic Rats. Implant Dent. 2015, 1-5. [CrossRef] [PubMed]

349. Hashiguchi, C.; Kawamoto, S.; Nishi, Y.; Nagaoka, E. In fluence of an Antidiabetic Drug on Biomechanical and Histological. Implant Dent. 2014, 23, 264-269. [CrossRef] [PubMed]

350. Kuchler, U.; Watzek, G.; Kuchler, U.; Spilka, T.; Baron, K.; Kuchler, U.; Spilka, T.; Baron, K.; Gruber, R. Intermittent parathyroid hormone fails to stimulate osseointegration in diabetic rats. Clin. oral Implant Res. 2011, 518-523. [CrossRef]

351. Zhang, J.; Shirai, M.; Yamamoto, R.; Yamakoshi, Y. Effect of Nerve Growth Factor on Osseointegration of Titanium Implants in Type 2 Diabetic Rats. Int. J. Oral Maxillofac. Implants 2016, 13-15. [CrossRef] [PubMed]

352. Han, Y.; Zeng, Q.; Lingling, E.; Liu, H. Sustained Topical Delivery of Insulin From Fibrin Gel Loaded With Poly ( LacticCo-Glycolic Acid ) Microspheres Improves the Biomechanical Retention of Titanium Implants in Type 1 Diabetic Rats. Dent. Implant. 2012, 2299-2308. [CrossRef]

353. Molon, R.S.D.; Morais-camilo, D.; Faeda, R.S.; Pepato, M.T.; Marcantonio-Junior, E. Impact of diabetes mellitus and metabolic control on bone healing around osseointegrated implants: Removal torque and histomorphometric analysis in rats. Clin. Oral Implants Res. 2012, 1-7. [CrossRef] [PubMed]

354. Zou, G.; Song, Y.; Zhou, W.; Yu, M.; Liang, L.; Zhu, W.-Z. Effects of local delivery of bFGF from PLGA microspheres on osseointegration around implants in diabetic rats. Oral Surg Oral Med Oral Pathol Oral Radiol. 2012, 114, 284-289. [CrossRef]

355. Faverani, L.P.; Ocon, T.; Polo, B.; Ramalho-ferreira, G.; Freire, A.R.; Prado, F.B.; Luvizuto, E.R. Raloxifene but not alendronate can compensate the impaired osseointegration in osteoporotic rats. Clin. Oral. Invest. 2018, 22, 255-265. [CrossRef] [PubMed]

356. Du, Z.; Chen, J.; Yan, F.; Doan, N.; Ivanovski, S.; Xiao, Y. Serum bone formation marker correlation with improved osseointegration in osteoporotic rats treated with simvastatin. Clin. Oral Implants Res. 2011, 1-6. [CrossRef] [PubMed]

357. Dikicier, E.; Karaçayl, Ü.; Dikicier, S.; Günaydin, Y. Effect of systemic administered zoledronic acid on osseointegration of a titanium implant in ovariectomized rats. J. Cranio-Maxiollo Facial Surg. 2014, 1-6. [CrossRef]

358. Pyo, S.W.; Kim, Y.M.; Kim, C.S.; Lee, I.S.; Park, J.U. Phosphate-Coated and Zoledronate-Immobilized Titanium Implants in Osteoporotic Rat Tibiae. JOMI 2014, 29, 478-484. [CrossRef] [PubMed]

359. Giro, G.; Coelho, P.G.; Rodrigues, R.M.; Jorgetti, V.; Orrico, S.R.P. The effect of oestrogen and alendronate therapies on postmenopausal bone loss around osseointegrated titanium implants. Clin. oral Implant Res. 2010, 259-264. [CrossRef]

360. Faverani, L.P.; Prado, F.B.; Garcia, I.R., Jr.; Okamoto, R. Raloxifene enhances peri-implant bone healing in osteoporotic rats. Int. J. Oral Maxillofac. Surg. 2015, 44, 798-805. [CrossRef]

361. Freitas de Paula, L.G.; Lopes de Oliveira, G.J.P.; Pinotti, F.E.; Grecchi, B.B.; Garcia de Aquino, S.; Marcantonio, R.A.C. Effect of Avocado/Soybean Unsaponifiables (ASU) on Osseointegration in Rats with Experimental Arthritis. Int. J. Oral Maxillofac. Implants 2018. [CrossRef]

362. Kuchler, U.; Luvizuto, E.; Watzek, G.; Gruber, R. Bone healing around titanium implants in two rat colitis models. Clin. oral Implant Res. 2012, 1-6. [CrossRef]

363. Belluci, M.M.; Andre, R.; Maria, R.; Pereira, R.; Belluci, M.M.; Giro, G.; Regina, S.; Orrico, P. Effects of magnesium intake deficiency on bone metabolism and bone tissue around osseointegrated implants. Clin. Oral Implants Res. 2010, 716-721. [CrossRef]

364. Yagihara, A.; Kawasaki, D.D.S.R.; Mita, M.A.; Takakuda, K. Impact of Dynamic and Static Load on Bone Around Implants: An Experimental Study in a Rat Model. JOMI 2016, 49-56. [CrossRef] [PubMed]

365. Anselm Wiskott, H.; Bonhote, P.; Cugnoni, J.; Zacchetti, G.; Scherrer, S.S.; Ammann, P. Implementation of the " loaded implant " model in the rat using a miniaturized setup-Description of the method and first results. Clin. Oral Implant Res. 2011, 1-8. [CrossRef]

366. Zhou, H.; Hou, Y.; Zhu, Z.; Xiao, W.; Xu, Q.; Li, L.; Li, X.; Chen, W. Effects of Low-Intensity Pulsed Ultrasound on Implant Osseointegration in Ovariectomized Rats. J. Ultrasound Med. 2 2016, 53-60. [CrossRef]

367. Boldrini, C.; De Almeida, J.M.; Garcia, V.G.; Theodoro, L.H. Biomechanical effect of one session of low-level laser on the bone-Titanium implant interface. Lasers Med. Sci. 2013, 349-352. [CrossRef] [PubMed]

368. Hirota, M.; Ozawa, T. Effects of ultraviolet Photofunctionalization on bone augmentation and integration capabilities of titanium mesh and implants. Oral Maxillofac. Implant. 2017, 32. [CrossRef] [PubMed]

369. Alghamdi, H.; Jansen, J. Calcium-phosphate-coated Oral Implants Promote Osseointegration in Osteoporosis. J. Dent. Res. 2013, 982-988. [CrossRef] 
370. Trandafir, V.; Pașca, S.; Sindilar, E.-V.; Dragan, E.; Odri, G.; Nemtoi, A.; Haba, D.; Elena, S.; Nemtoi, A. Osseointegration of chemically modified sandblasted and acid-etched titanium implant surface in diabetic rats: A histological and scanning electron microscopy study. Rom. J. Morphol. Embryol. 2017, 58, 881-886.

371. Liu, Z.; Zhou, W.; Tangl, S.; Liu, S.; Xu, X. Potential mechanism for osseointegration of dental implants in Zucker diabetic fatty rats. Br. J. Oral Maxillofac. Surg. 2015, 4-9. [CrossRef] [PubMed]

372. Zhou, W.; Liu, Z.; Yao, J.; Chi, F.; Dong, K. The Effects of Exenatide Microsphere on Serum BGP and ALP Levels in ZDF Rats. Clin. Implant. Dent. 2015, 765-770. [CrossRef]

373. Watanabe, T.; Nakada, H.; Takahashi, T.; Fujita, K.; Tanimoto, Y. Potential for acceleration of bone formation after implant surgery by using a dietary supplement: An animal study. Oral Rehabil. 2015, 46, 447-453. [CrossRef]

374. Okamoto, Y.; Tateishi, H.; Kinoshita, K.; Hibi, H.; Ueda, M. An Experimental Study of Bone Healing Around the Titanium Screw Implants in Ovariectomized Rats: Enhancement of Bone Healing by Bone Marrow Stromal. Implant Dent. 2011, 20, 236-245. [CrossRef]

375. DU, Z.; Lee, R.S.B.; Xiao, Y. Evaluation of the first maxillary molar post-extraction socket as a model for dental implant osseointegration. Clin. Oral Implant Res. 2015, 1-10. [CrossRef]

376. Miyamoto, N.; Yamachika, R.; Sakurai, T.; Hayakawa, T.; Hosoya, N. Bone Response to Titanium Implants Coated with Doubleor Single-Stranded DNA. Biomed Res. Int. 2018, 2018, 9204391. [CrossRef]

377. Shah, F.; Stål, P.; Li, J.; Sessle, B.J.; Avivi-arber, L. Tooth extraction and subsequent dental implant placement in Sprague- Dawley rats induce differential changes in anterior digastric myofibre size and myosin heavy chain isoform expression. Arch. Oral Biol. 2019, 99, 141-149. [CrossRef]

378. Sun, J.; Eberhard, J.; Glage, S.; Held, N.; Voigt, H.; Schwabe, K.; Winkel, A.; Stiesch, M. Development of a peri-implantitis model in the rat. Clin. Oral Implants Res. 2020, 31, 203-214. [CrossRef] [PubMed]

379. Yue, G.; Edani, H.; Sullivan, A.; Jiang, S.; Kazerani, H.; Saghiri, M.A. Is maxillary diastema an appropriate site for implantation in rats? Int. J. Implant Dent. 2020, 6, 8. [CrossRef] [PubMed]

380. Nagasawa, M.; Takano, R. Observation of the Bone Surrounding an overlpaded implant in a Novel rat model. Int. J. Oral Maxillofac. Implants 2013, 109-116. [CrossRef]

381. Avivi-arber, L.; Lee, J.; Sood, M.; Lakschevitz, F.; Fung, M.; Barashi-gozal, M.; Glogauer, M.; Sessle, B.J. Long-Term Neuroplasticity of the Face Primary Motor Cortex and Adjacent Somatosensory Cortex Induced by Tooth Loss Can Be Reversed Following Dental Implant Replacement in Rats. J. Comp. Neurol. 2015, 2389, 2372-2389. [CrossRef] [PubMed]

382. Oh, K.C.; Moon, H.S.; Lee, J.H.; Park, Y.B.; Kim, J. Effects of alendronate on the peri-implant bone in rats. Oral Dis. 2015, $248-256$. [CrossRef] [PubMed]

383. Inouye, K.A.S.; Bisch, F.C.; Elsalanty, M.E.; Zakhary, I.; Khashaba, R.M.; Borke, J.L. Effect of Metformin on Periimplant Wound Healing in a Rat Model of Type 2 Diabetes. Implant Dent. 2014, 23, 319-327. [CrossRef] [PubMed]

384. Quintero, D.G.; Winger, J.N.; Khashaba, R.; Borke, J.L. Advanced Glycation Endproducts and rat dental implant osseointegration. J. Oral Implantol. 2010, 97-103. [CrossRef]

385. Freira, M.; Zadeh, H. Development of an Animal Model for Aggregatibacter Actinomycetemcomitans Biofilm-Mediated Oral Osteolytic Infection: A. J. Periodontol. 2010, 82. [CrossRef]

386. Wen, B.; Karl, M.; Pendrys, D.; Shafer, D.; Freilich, M.; Kuhn, L. An evaluation of BMP-2 delivery from scaffolds with miniaturized dental implants in a novel rat mandible model. J. Biomed. Mater. Res. B 2011, 97, 315-326. [CrossRef] [PubMed]

387. Lee, Y.; Bhattarai, G.; Park, I.; Kim, G.; Kim, G.; Lee, M.; Yi, H. Biomaterials Bone regeneration around N -acetyl cysteine-loaded nanotube titanium dental implant in rat mandible. Biomaterials 2013, 34, 10199-10208. [CrossRef] [PubMed]

388. Jin, Q.; Cirelli, J.A.; Park, C.H.; Sugai, J.V.; Taba, M., Jr.; Kostenuik, P.J.; Giannobile, W. V RANKL inhibition through osteoprotegerin blocks bone loss in experimental periodontitis. J. Periodontol. 2007, 78, 1300-1308. [CrossRef] [PubMed]

389. Riool, M.; De Boer, L.; Jaspers, V.; Van Der Loos, C.M.; Van Wamel, W.J.B.; Wu, G.; Kwakman, P.H.S.; Zaat, S.A.J. Staphylococcus epidermidis originating from titanium implants infects surrounding tissue and immune cells. Acta Biomater. 2014, 10, $5202-5212$. [CrossRef] [PubMed]

390. Maluf, A.P.; Maluf, R.P.; Da Rocha Brito, C.; França, F.M.G.; De Brito, R.B. Mechanical evaluation of the influence of low-level laser therapy in secondary stability of implants in mice shinbones. Lasers Med. Sci. 2010, 25, 693-698. [CrossRef]

391. Beppu, K.; Kido, H.; Watazu, A.; Teraoka, K.; Matsuura, M. Peri-implant bone density in senile osteoporosis-changes from implant placement to osseointegration. Clin. Implant Dent. Relat. Res. 2013, 15, 217-226. [CrossRef] [PubMed]

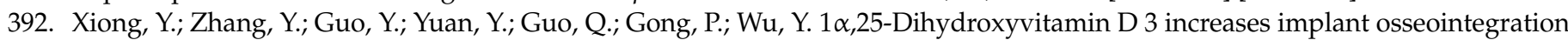
in diabetic mice partly through FoxO1 inactivation in osteoblasts. Biochem. Biophys. Res. Commun. 2017, 494, 626-633. [CrossRef]

393. Oh, S.M.; Shin, J.S.; Kim, I.K.; Kim, J.H.; Moon, J.S.; Lee, S.K.; Lee, J.H. Therapeutic effects of HIF-1 $\alpha$ on bone formation around implants in diabetic mice using cell-penetrating DNA-binding protein. Molecules 2019, 24. [CrossRef]

394. Xiang, L.; Ma, L.; Wei, N.; Wang, T.; Yao, Q.; Yang, B.; Xiong, Y.; Wu, Y.; Gong, P. Effect of lentiviral vector overexpression $\alpha$-calcitonin gene-related peptide on titanium implant osseointegration in $\alpha$-CGRP-deficient mice. Bone 2017, 94, 135-140. [CrossRef] [PubMed]

395. Morinaga, K.; Sasaki, H.; Park, S.; Hokugo, A.; Okawa, H.; Colwell, C.S.; Nishimura, I.; Angeles, L.; Implantology, M.; Angeles, L.; et al. Neuronal PAS domain 2 (Npas2) facilitated osseointegration of titanium implant with rough surface through a neuroskeletal mechanism. Biomaterials 2020, 62-74. [CrossRef] 
396. Becker, S.T.; Föge, M.; Beck-Broichsitter, B.E.; Gavrilova, O.; Bolte, H.; Rosenstiel, P.; Wiltfang, J. Induction of periimplantitis in dental implants. J. Craniofac. Surg. 2013, 24, 15-18. [CrossRef]

397. Mouraret, S.; Hunter, D.J.; Bardet, C.; Popelut, A.; Brunski, J.B.; Chaussain, C.; Bouchard, P.; Helms, J.A. Improving oral implant osseointegration in a murine model via Wnt signal amplification. J. Clin. Periodontol. 2014, 41, 172-180. [CrossRef] [PubMed]

398. Biguetti, C.C.; Cavalla, F.; Silveira, E.M.; Fonseca, A.C.; Vieira, A.E.; Tabanez, A.P.; Rodrigues, D.C.; Trombone, A.P.F.; Garlet, G.P. Oral implant osseointegration model in C57Bl/6 mice: Microtomographic, histological, histomorphometric and molecular characterization. J. Appl. oral Sci. 2018, 26, e20170601. [CrossRef]

399. Yuan, X.; Pei, X.; Zhao, Y.; Li, Z.; Chen, C.H.; Tulu, U.S.; Liu, B.; Van Brunt, L.A.; Brunski, J.B.; Helms, J.A. Biomechanics of Immediate Postextraction Implant Osseointegration. J. Dent. Res. 2018, 97, 987-994. [CrossRef] [PubMed]

400. Watanabe, T.; Nakagawa, E.; Saito, K.; Ohshima, H. Differences in Healing Patterns of the Bone-Implant Interface between Immediately and Delayed-Placed Titanium Implants in Mouse Maxillae. Clin. Implant Dent. Relat. Res. 2016, 18, 146-160. [CrossRef]

401. Wang, L.; Wu, Y.; Perez, K.C.; Hyman, S.; Brunski, J.B.; Tulu, U.; Bao, C.; Salmon, B.; Helms, J.A. Effects of Condensation on Peri-implant Bone Density and Remodeling. J. Dent. Res. 2017, 96, 413-420. [CrossRef]

402. Heyman, O.; Koren, N.; Mizraji, G.; Capucha, T.; Wald, S.; Nassar, M.; Tabib, Y.; Shapira, L.; Hovav, A.H.; Wilensky, A. Impaired differentiation of Langerhans cells in the murine oral epithelium adjacent to titanium dental implants. Front. Immunol. 2018, 9 , 1-14. [CrossRef] [PubMed]

403. Lee, D.J.; Lee, J.M.; Kim, E.J.; Takata, T.; Abiko, Y.; Okano, T.; Green, D.W.; Shimono, M.; Jung, H.S. Bio-implant as a novel restoration for tooth loss. Sci. Rep. 2017, 7, 1-10. [CrossRef] [PubMed]

404. Pirih, F.Q.; Hiyari, S.; Barroso, A.D.V.; Jorge, A.C.A.; Perussolo, J.; Atti, E.; Tetradis, S.; Camargo, P.M. Ligature-induced peri-implantitis in mice. J. Periodontal Res. 2015, 50, 519-524. [CrossRef] [PubMed]

405. Pirih, F.; Hiyari, S.; Tetradis, S.; Camargo, P. A Murine Model of Lipopolysaccharide-Induced Peri-Implant Mucositis and Peri-implantitis. J. Oral Implantol. 2015, 41, e158-e164. [CrossRef] [PubMed]

406. Nguyen Vo, T.N.; Hao, J.; Chou, J.; Oshima, M.; Aoki, K.; Kuroda, S.; Kaboosaya, B.; Kasugai, S. Ligature induced peri-implantitis: Tissue destruction and inflammatory progression in a murine model. Clin. Oral Implants Res. 2017, 28, 129-136. [CrossRef]

407. Pirih, F.; Camargo, P. Ligature-induced peri-implantitis in mice. J. Periodontal Res. 2017, 176, 139-148. [CrossRef] [PubMed]

408. Tzach-Nahman, R.; Mizraji, G.; Shapira, L.; Nussbaum, G.; Wilensky, A. Oral infection with P. gingivalis induces peri-implantitis in a murine model: Evaluation of bone loss and the local inflammatory response. J. Clin. Periodontol. 2017, 44, 739-748. [CrossRef] [PubMed]

409. Ding, L.; Zhang, P.; Wang, X.; Kasugai, S. A doxycycline-treated hydroxyapatite implant surface attenuates the progression of peri-implantitis: A radiographic and histological study in mice. Clin. Implant Dent. Relat. Res. 2019, 21, 154-159. [CrossRef] [PubMed]

410. Yu, X.; Hu, Y.; Freire, M.; Yu, P.; Kawai, T.; Han, X. Role of toll-like receptor 2 in inflammation and alveolar bone loss in experimental peri-implantitis versus periodontitis. J. Periodontal. Res. 2018, 53, 98-106. [CrossRef] [PubMed] 